US Army Corps

of Engineers

Waterways Experiment

Station

\title{
Three-Dimensional Breakwater Stability Tests at Vale de Cavaleiros, Cape Verde
}

\author{
by Ernest R. Smith, Jeffrey A. Melby
}

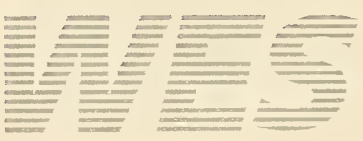

Approved For Public Release; Distribution Is Unlimited

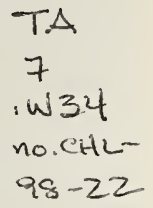

Prepared for Joint Venture RRI-BCEOM 
The contents of this report are not to be used for advertising, publication, or promotional purposes. Citation of trade names does not constitute an official endorsement or approval of the use of such commercial products.

The findings of this report are not to be construed as an official Department of the Army position, unless so designated by other authorized documents. 


\section{Three-Dimensional Breakwater Stability Tests at Vale de Cavaleiros, Cape Verde}

by Ernest R. Smith, Jeffrey A. Melby

U.S. Army Corps of Engineers

Waterways Experiment Station 3909 Halls Ferry Road

Vicksburg, MS 39180-6199

\section{Final report}

Approved for public release; distribution is unlimited 


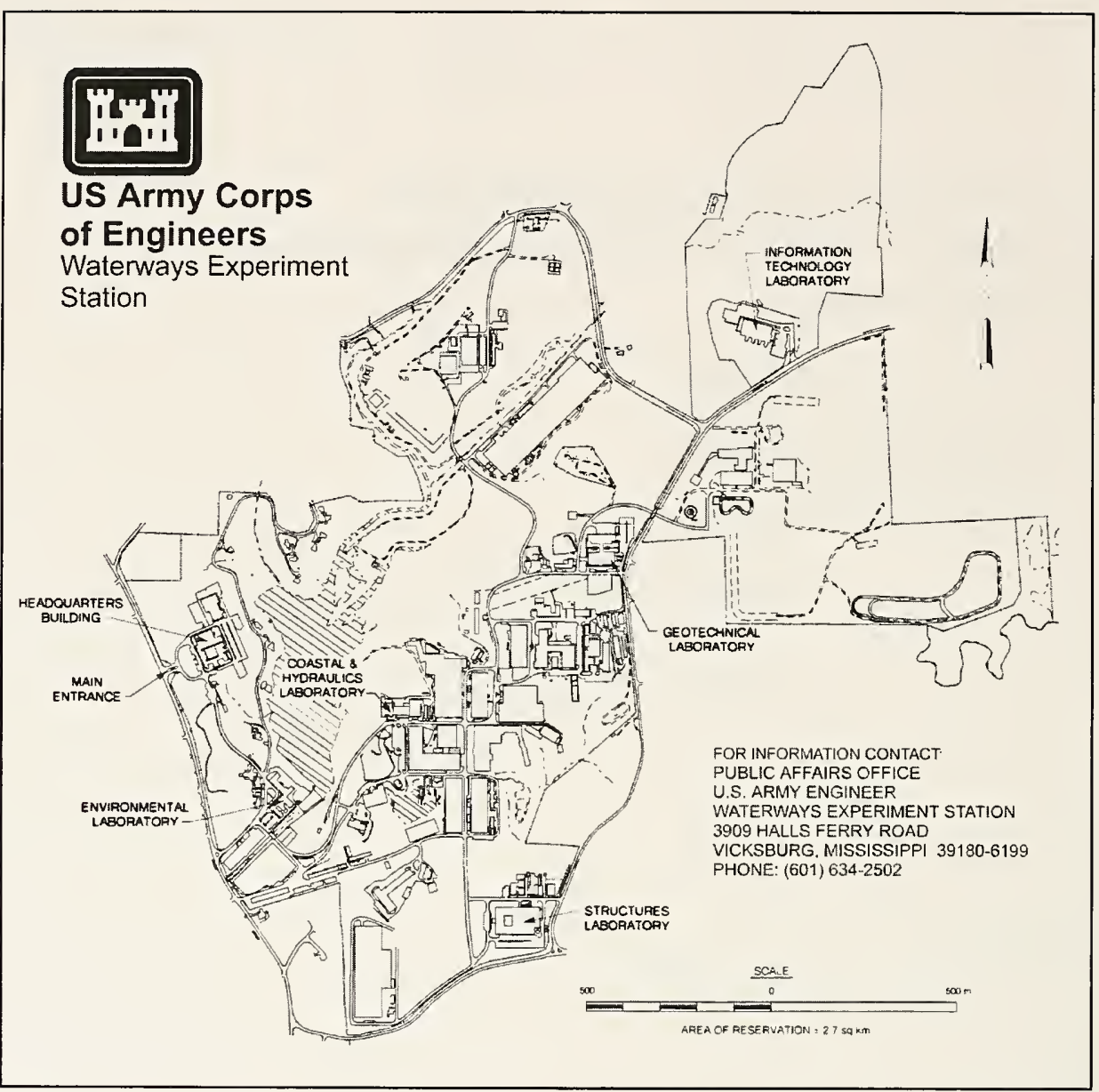

Waterways Experiment Station Cataloging-in-Publication Data

Smith, Ernest R.

Three-dimensional breakwater stability tests at Vale de Cavaleiros, Cape Verde / by

Ernest R. Smith, Jeffrey A. Melby ; prepared for Joint Venture RRI-BCEOM.

79 p. : ill. ; $28 \mathrm{~cm}$. - (Technical report ; CHL-98-22)

Includes bibliographic references.

1. Armourstone - Cape Verde. 2. Breakwaters - Cape Verde. 3. Seawalls - Cape Verde. 4. Cape Verde. I. Melby, Jeffrey A. II. United States. Army. Corps of Engineers. III. U.S. Army Engineer Waterways Experiment Station. IV. Coastal and Hydraulics Laboratory (U.S. Army Engineer Waterways Experiment Station) V. Joint Venture Rhein Ruhr Ingenieur-Gesellschaft mbH and BCEOM Societe Francaise d'Ingenierie. VI. Title. VII. Series: Technical report (U.S. Army Engineer Waterways Experiment Station) ; CHL-98-22.

TA7 W34 no.CHL-98-22 


\section{Contents}

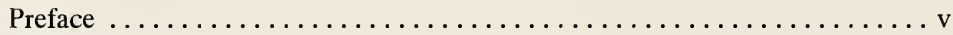

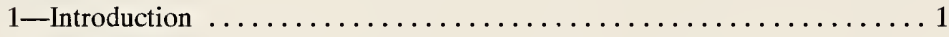

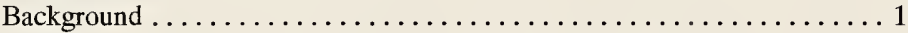

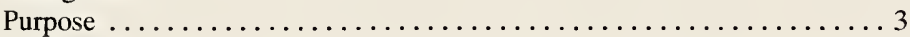

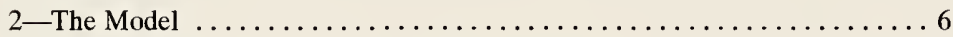

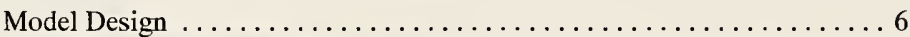

Experiment Facilities and Equipment $\ldots \ldots \ldots \ldots \ldots \ldots \ldots \ldots \ldots \ldots \ldots \ldots \ldots \ldots$

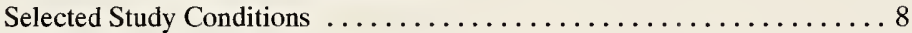

Experiment Procedures . . . . . . . . . . . . . . . . . . . 9

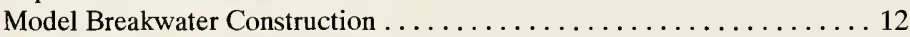

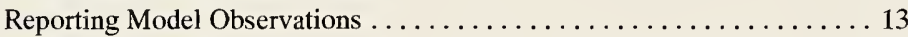

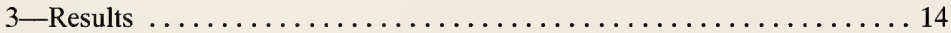

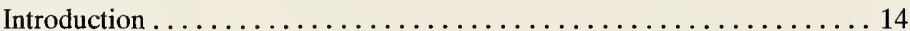

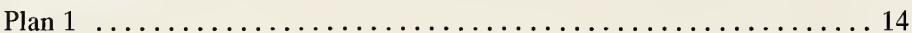

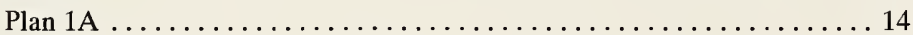

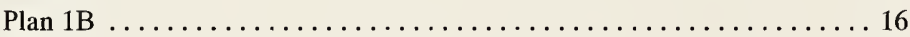

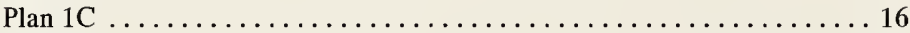

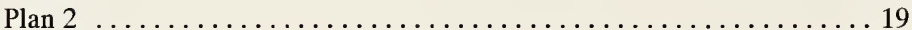

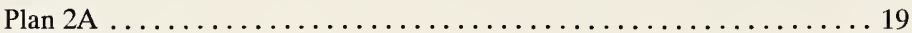

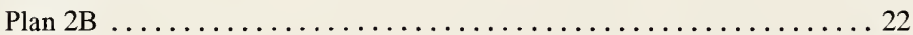

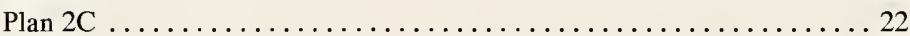

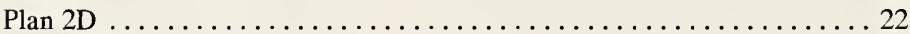

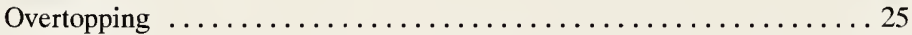

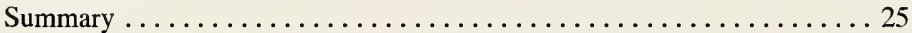

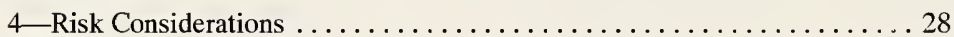

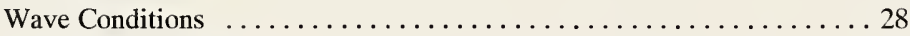

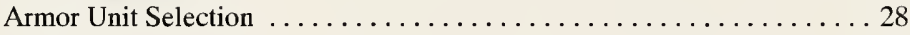

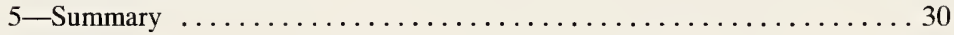

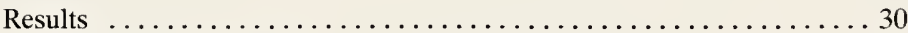

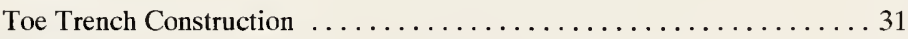

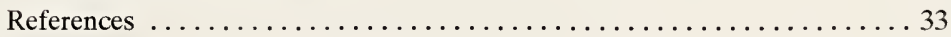


Appendix A: Photographs ........................ A1

Appendix B: Notation ........................... B1

SF 298

\section{List of Figures}

Figure 1. Location of Cape Verde $\ldots \ldots \ldots \ldots \ldots \ldots \ldots \ldots \ldots \ldots$

Figure 2. Cape Verde Islands $\ldots \ldots \ldots \ldots \ldots \ldots \ldots \ldots \ldots \ldots \ldots \ldots \ldots \ldots \ldots \ldots \ldots \ldots \ldots$

Figure 3. Existing site location map $\ldots \ldots \ldots \ldots \ldots \ldots \ldots \ldots \ldots$

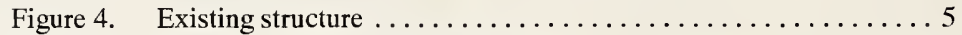

Figure 5. Three-dimensional stability model $\ldots \ldots \ldots \ldots \ldots \ldots \ldots \ldots$

Figure 6. Three-dimensional model boundaries and wave gauge

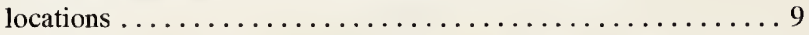

Figure 7. $H_{s}^{\prime}$ at $-21.3 \mathrm{~m} \mathrm{CD}$ versus generator stroke, $13-\mathrm{sec}$ waves ...... 10

Figure 8. $\quad H_{s}{ }^{\prime}$ at $-21.3 \mathrm{~m} \mathrm{CD}$ versus generator stroke, 16 -sec waves . . . . 10

Figure 9. $H_{s}{ }^{\prime}$ at $-21.3 \mathrm{~m} \mathrm{CD}$ versus generator stroke, $19-\mathrm{sec}$ waves . . . . 11

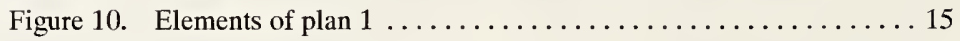

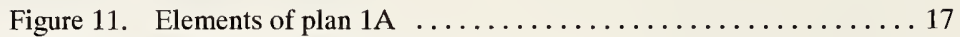

Figure 12. Elements of plans $1 \mathrm{~B}$ and $1 \mathrm{C} \ldots \ldots \ldots \ldots \ldots \ldots \ldots \ldots \ldots$

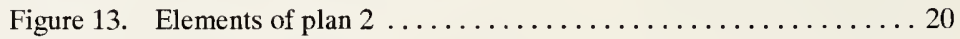

Figure 14. Elements of plan $2 \mathrm{~A} \ldots \ldots \ldots \ldots \ldots \ldots \ldots \ldots \ldots \ldots \ldots \ldots \ldots \ldots \ldots \ldots \ldots$

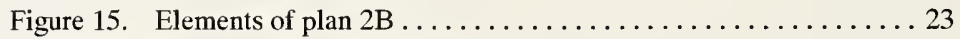

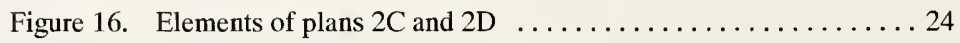

Figure 17. Wave overtopping at trunk, all plans $\ldots \ldots \ldots \ldots \ldots \ldots \ldots$

Figure 18. Wave overtopping at breakwater head, plan 1 series waves . . . . 26

Figure 19. Wave overtopping at breakwater head, plan 2 series waves . . . 27

Figure 20. Example of toe trench constructed on rocky bottom ....... 31

Figure 21. Example of toe trench constructed on sandy bottom . . . . . 32 


\section{Preface}

The model investigation of the Vale de Cavaleiros breakwater reported herein was requested by Joint Venture Rhein Ruhr Ingenieur-Gesellschaft mbH (RRI) and BCEOM Société Française d'Ingénierie (JV RRI-BCEOM) and was conducted at the Coastal Engineering Research Center (CERC) of the U. S. Army Engineer Waterways Experiment Station(WES). In October 1996, CERC merged with the WES Hydraulics Laboratory to become the Coastal and Hydraulics Laboratory. Authorization for WES to perform the study was granted by Cooperative Research and Development Act (CRDA) No. WES-96CERC-01 dated 11 January 1996.

The study was conducted at WES during the period January 1996 through May 1996 by personnel of the Coastal Structures Branch (CSB) of the Navigation and Harbors Division (NHD), CHL, under the direction of Dr. James R. Houston and Mr. Charles C. Calhoun, Jr., Director and Assistant Director of CHL, respectively; and the direct guidance of Messrs. C. E. Chatham, Jr., Chief of NHD; and Mr. D. D. Davidson, Chief of CSB. The physical model was designed by Messrs. Ernest R. Smith and Jeffrey A. Melby, Research Hydraulic Engineers, CSB. Experiments were conducted by Messrs. Smith, Willie G. Dubose, Civil Engineering Technician; John H. Williams, Civil Engineering Technician; Johnny Heggins, Civil Engineering Technician; and David Daily, Instrumentation Services Technician, NHD. This report was prepared by Messrs. Smith and Melby.

Liaison was maintained with JV RRI-BCEOM through progress reports and telephone conversations during the course of the investigation. Prior to construction of the breakwater cross section, Mr. A. Merrien, France, visited WES during 20 to 22 March 1996 to discuss proposed test conditions.

Messrs. Merrien and L. Fischer, Germany, visited WES on 17 and 18 April 1996 to observe experiments and discuss alternative breakwater plans.

At the time of publication of this report, Director of WES was Dr. Robert W. Whalin. Commander of WES was COL Robin R. Cababa, EN.

The contents of this report are not to be used for advertising, publication, or promotional purposes. Citation of trade names does not constitute an official endorsement or approval of the use of such commercial products. 


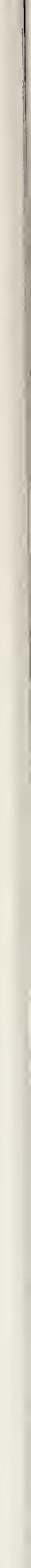




\section{Introduction}

\section{Background}

Vale de Cavaleiros is a small port on the west coast of the Island of Fogo, Republic of Cape Verde. Maps of the region and harbor are shown in Figures 1 and 2 , respectively. The harbor is manmade, being enclosed by breakwaters extending from a natural cape. The harbor provides shelter for local fishing and commercial cargo vessels, and recreational beach use. Commercial cargo vessels are loaded and unloaded using local lighterage.

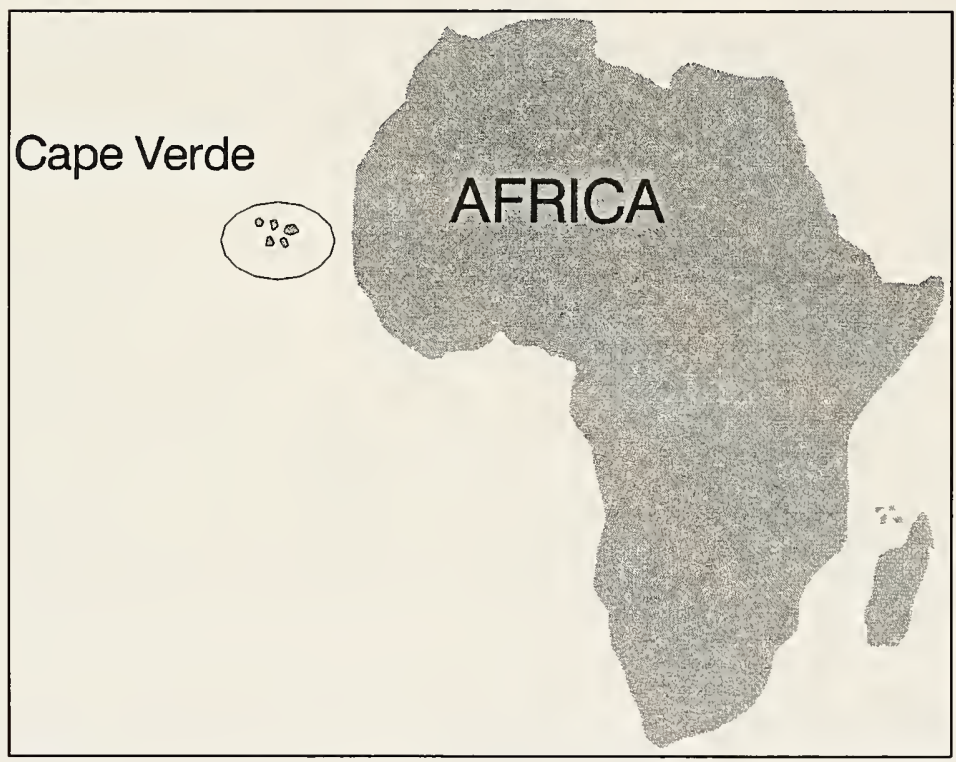

Figure 1. Location of Cape Verde 


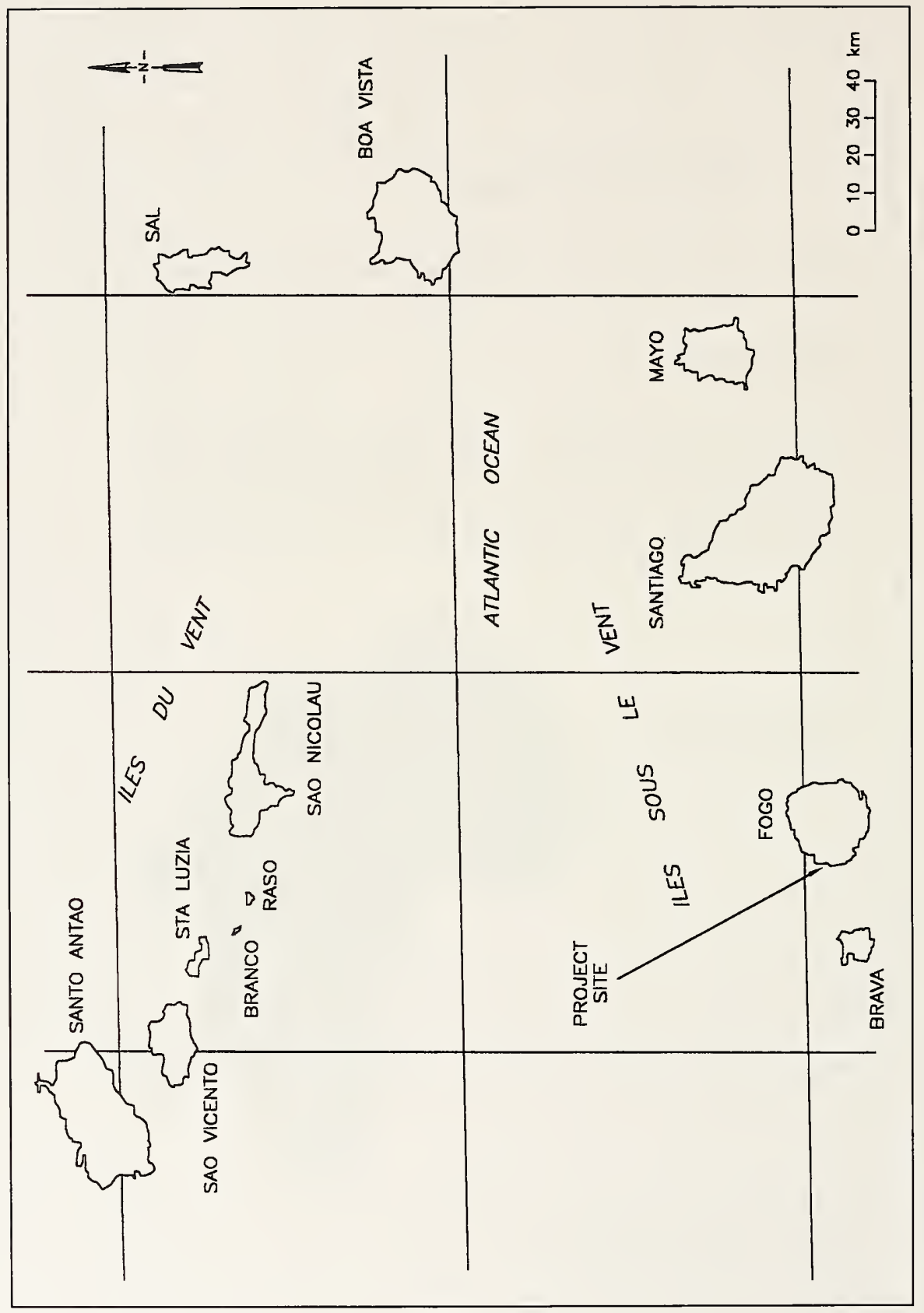

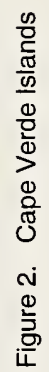


The site is exposed to Atlantic Ocean storms, with predominant swell from $300 \mathrm{deg}$ north in the winter months. The sponsor-predicted 50-year return period wave height ranged from 6.7 to $7.5 \mathrm{~m}$. A secondary summer storm swell is incident from approximately 230 deg north.

The existing main breakwater is shown in Figures 3 and 4, with the layout view in Figure 4 dividing the breakwater into seven profiles. The porous breakwater consists of a traditional rubble mound fronting a recurved seawall. The crest elevation of the seawall is $+8.15 \mathrm{~m} \mathrm{CD}$ (CD refers to the lowest theoretical chart datum) while the crest elevation of the 6.25-tonne-tetrapod armor layer is approximately $+7 \mathrm{~m} \mathrm{CD}$. The head of the breakwater was virtually destroyed by storms over 25 years and its remnants are completely submerged. The remaining tetrapod-armored trunk section extends south for approximately $180 \mathrm{~m}$ from Profile 1 (Figure 4). The existing tetrapod section extends down to approximately $0 \mathrm{~m} \mathrm{CD}$.

The depth along the toe varies from near $2 \mathrm{~m}$ along the trunk to $9 \mathrm{~m}$ on the head, so the significant wave in the design spectrum is depth limited. The water level can vary up to $2 \mathrm{~m}$ due to a combination of both tide and storm surge. The seaward bottom slope is relatively steep, averaging between $1 \mathrm{~V}$ on $12 \mathrm{H}$ to $1 \mathrm{~V}$ on $15 \mathrm{H}$. The foundation at the site consists of layers of sand over bedrock or old breakwater remnants with sporadic rock outcroppings. Net littoral drift is to the south.

Much of the trunk section shows considerable damage to the existing tetrapod armoring. The main armor of tetrapods was under-designed for the 50-year return period, 7-m significant wave height at the head. Tetrapods along the trunk section north of Profile 4 have remained relatively stable.

\section{Purpose}

A breakwater rehabilitation has been proposed for Vale de Cavaleiros. The rehabilitation would include extending the breakwater length, placing all salvageable tetrapods in Profiles 1 through 4, and placing Core-Loc armor units on the remainder of the structure. At the request of Joint Venture Rhein Ruhr Ingenieur-Gesellschaft $\mathrm{mbH}$ and BCEOM Société Française d'Ingénierie (JV RRI-BCEOM), a breakwater stability model investigation was initiated by the U.S. Army Engineer Waterways Experiment Station's Coastal Engineering Research Center. The study goal was to evaluate the stability of the Core-Loc armor layer for the proposed rehabilitation of the breakwater.

This report describes the design and facilities used (Chapter 2), and results of the three-dimensional stability study (Chapter 3). The study is summarized in Chapter 4. Appendix A contains photographs of the three-dimensional model and Appendix B includes symbol notation used in the report. 


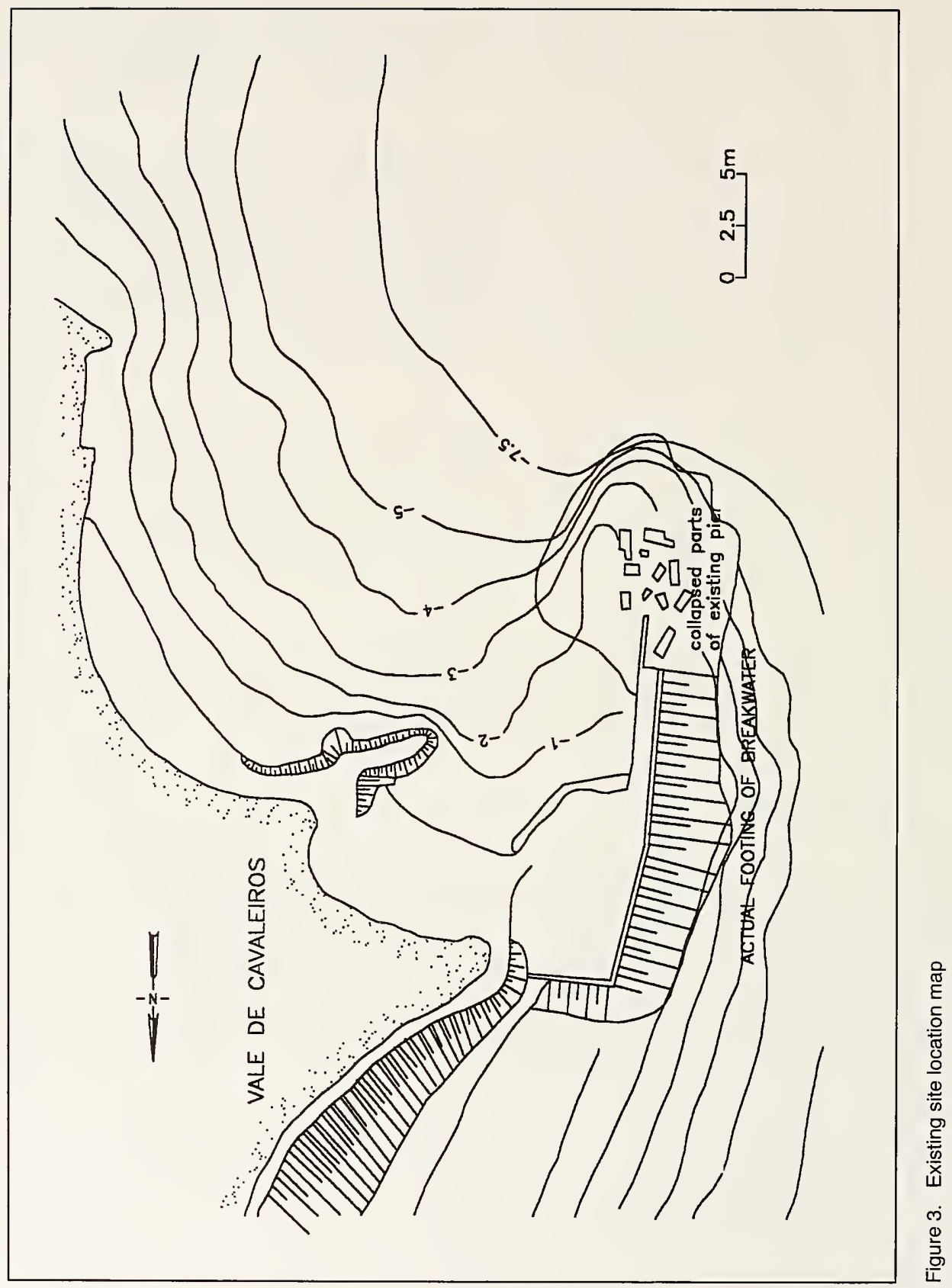




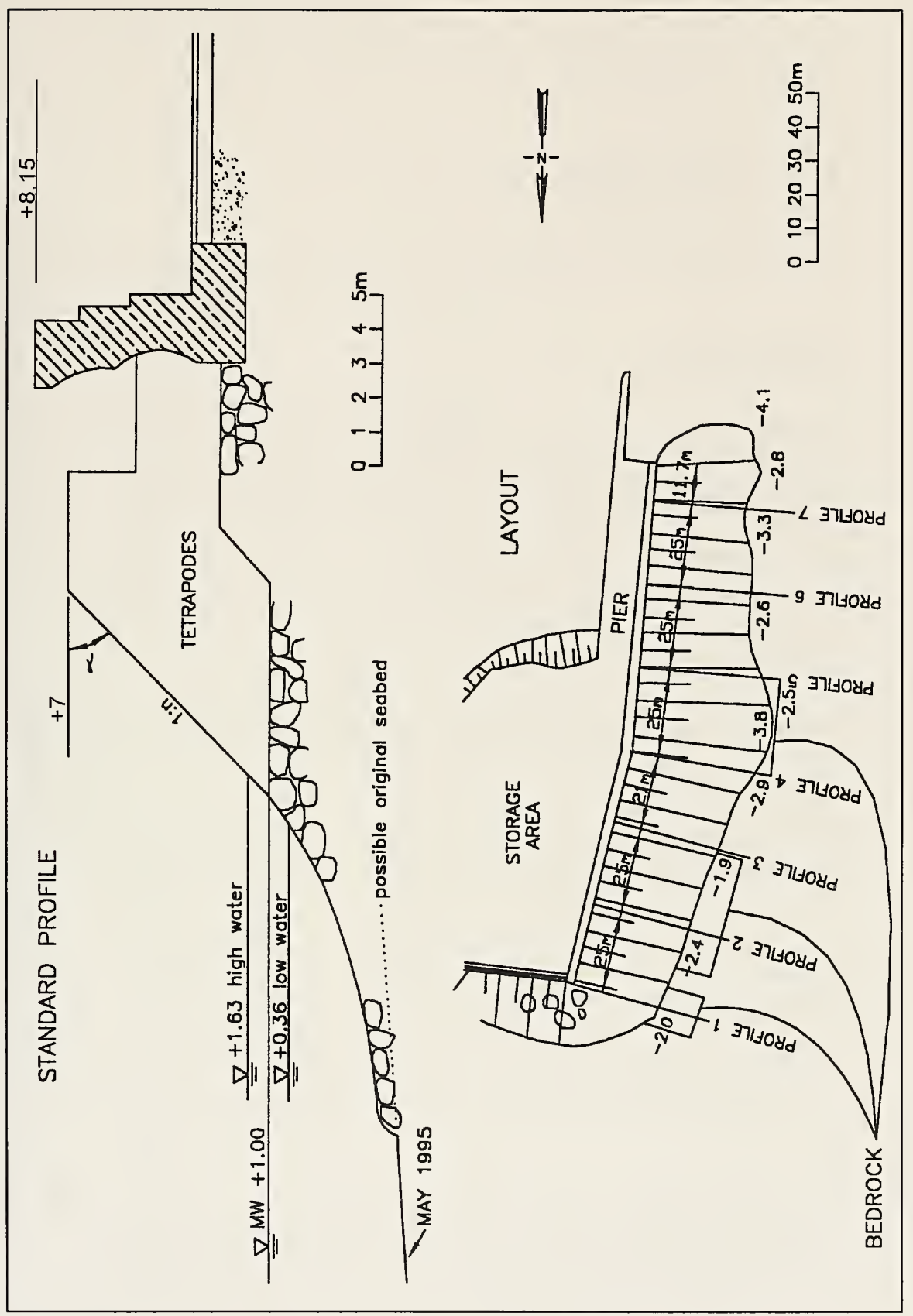

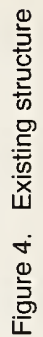




\section{The Model}

\section{Model Design}

Model experiments were conducted at a geometrically undistorted linear scale of $1: 48.4$, model to prototype. Scale was based on the size availability of model armor units and the capabilities of the available wave generator to produce required wave heights at modeled water depths. Time relations were scaled according to Froude Model Law (Stevens et al. 1942) and model-prototype relations were defined in terms of length $l$ and time $t$ shown in Table 1.

\begin{tabular}{||l|l|l||}
\hline $\begin{array}{l}\text { Table 1 } \\
\text { Model-Prototype Scale Relations (1:48.4 scale) }\end{array}$ \\
\hline \hline & Dimension & $\begin{array}{l}\text { Scale Relations } \\
\text { Model:Prototype }\end{array}$ \\
Characteristic & 1 & $t_{t}=1: 48.4$ \\
\hline \hline Length & $1^{2}$ & $a_{t}=1: 2342.6$ \\
\hline Area & $1^{3}$ & $v_{s}=1: 113,380$ \\
\hline Volume & $1^{1 / 2}$ & $t_{s}=1: 6.96$ \\
\hline Time &
\end{tabular}

The specific weights of water and construction materials differed between the model and prototype; therefore, the transference equation of Hudson (1975) was used to determine model material weights:

$$
\frac{\left(W_{a}\right)_{m}}{\left(W_{a}\right)_{p}}=\frac{\left(\gamma_{a}\right)_{m}}{\left(\gamma_{a}\right)_{p}}\left(\frac{l_{m}}{l_{p}}\right)^{3}\left[\frac{\left(S_{a}\right)_{p}-1}{\left(S_{a}\right)_{m}-1}\right]^{3}
$$

where

$$
\begin{aligned}
& m=\text { model quantities } \\
& p=\text { prototype quantities }
\end{aligned}
$$


$W_{a}=$ weight of individual armor or stone

$\gamma_{a}=$ specific weight of an individual armor unit or stone

$l_{m} / l_{p}=$ linear scale of the model

$S_{a}=$ specific gravity of an individual armor unit or stone relative to the water in which it is placed; $\gamma_{\gamma} / \gamma_{w}$, in which $\gamma_{w}$ is specific weight of water

Material sizes and densities for prototype and model armor layer $W_{1}$, underlayer $W_{2}$, and core $W_{3}$ are listed in Table 2 .

\section{Table 2 \\ Prototype and Model Material Sizes}

\begin{tabular}{||l|l|l|l|l||}
\hline \multirow{2}{*}{ Material } & \multicolumn{2}{|c|}{ Prototype } & \multicolumn{2}{c||}{ Model } \\
\cline { 2 - 5 } & $S_{a}$ & $W_{a}$ & $S_{a}$ & $W_{a}$ \\
\hline \hline$W_{1}$ & 2.62 & 11 tonnes & 2.29 & $145.2 \mathrm{~g}$ \\
\hline$W_{1}$ & 2.62 & 8 tonnes & 2.28 & $104.3 \mathrm{~g}$ \\
\hline$W_{2}$ & $2.9-3.1$ & $750-1800 \mathrm{~kg}$ & 2.65 & $9.2-22.1 \mathrm{~g}$ \\
\hline$W_{3}$ & $2.9-3.1$ & $12.5-250 \mathrm{~kg}$ & 2.65 & $0.15-3.1 \mathrm{~g}$ \\
\hline
\end{tabular}

\section{Experiment Facilities and Equipment}

Experiments were conducted in a 29.3-m-long, 29.6-m-wide, 1.5-m-deep wave basin. The model was constructed and molded of concrete to represent approximately $825 \mathrm{~m}$ of shoreline encompassing the harbor and breakwater location. Contours were molded to $-20 \mathrm{~m} \mathrm{CD}$, and a $1 \mathrm{~V}$ on $5 \mathrm{H}$ transition slope was molded from the $-20-\mathrm{m}$ contour to the model floor elevation of $-21.3 \mathrm{~m} \mathrm{CD}$. Wave absorber was placed around the perimeter of the basin to minimize the effects of reflection. A photograph of the model is shown in Figure 5.

Waves were generated by a piston-type electronically controlled hydraulic system. Displacement of the wave board was controlled by a command signal transmitted to the board by a DEC Micro VAX II computer, and waves were produced by the periodic displacement of the board. Irregular wave command signals to drive the board were generated to simulate a Texel, Marsen, and Arsloe (TMA) shallow-water spectrum (Hughes 1984) for the design wave periods.

Water surface elevations were recorded by single wire capacitance-type gauges, sampled at $20 \mathrm{~Hz}$. Eight gauges were used for calibration and testing. Three gauges (Gauges 1 through 3 ) were positioned on the flat portion of the model floor $(-21.3 \mathrm{~m} \mathrm{CD}) 3 \mathrm{~m}$ from the generator in an array that allowed 


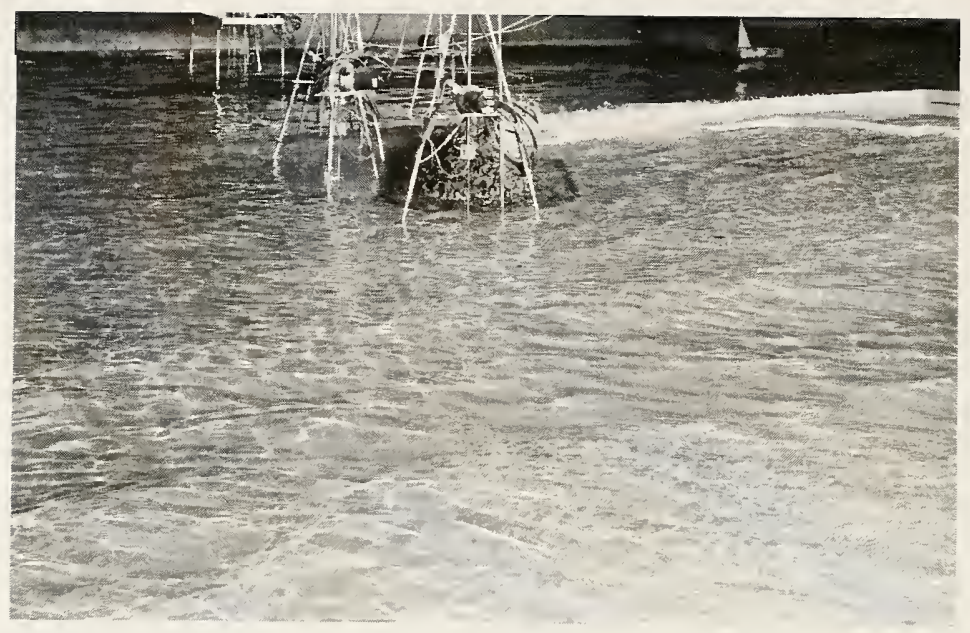

Figure 5. Three-dimensional stability model

calculation of incident and reflected wave heights by Goda and Suzuki (1976). The remaining gauges were placed at locations around the breakwater shown in Figure 6. Data obtained from the gauges were analyzed using the Time Series Analysis (TSA) computer program of Long and Ward (1987). Operations performed on wave data from individual gauges were mean down-crossing analysis to obtain significant wave height $H_{s}$, maximum and average wave heights, significant and average wave periods, and mean water levels at each gauge. Operations performed on the wave gauge array were unidirectional spectral density incident/reflection analysis to determine peak wave period $T_{p}$, and incident and reflected wave heights at the gauge array. Following calibration of the basin, Gauges 4 and 5 were removed and used in locations 9 and 10 during stability tests.

\section{Selected Study Conditions}

As indicated in Chapter 1 the most severe wave conditions approached the harbor from 300 deg from north; therefore, all tests were conducted for waves approaching from this direction. Prior to construction of the breakwater, wave absorber was placed over the quay wall to minimize reflection and the basin was calibrated for the design periods from the $300-\mathrm{deg}$ direction. The selected water depth for all experiments was $+1.8 \mathrm{~m} \mathrm{CD}$, which was based on tide and surge, and the design periods were 13,16 , and $19 \mathrm{sec}$. The maximum design storm wave height was defined by the sponsor to be as high as $6.7 \mathrm{~m}$ at the $-21 \mathrm{~m} \mathrm{CD}$ contour.

Incident significant wave height $H_{s}^{\prime}$ obtained from Gauges 1 through 3 during calibration is plotted versus percent of generator stroke in Figures 7 through 9 . 


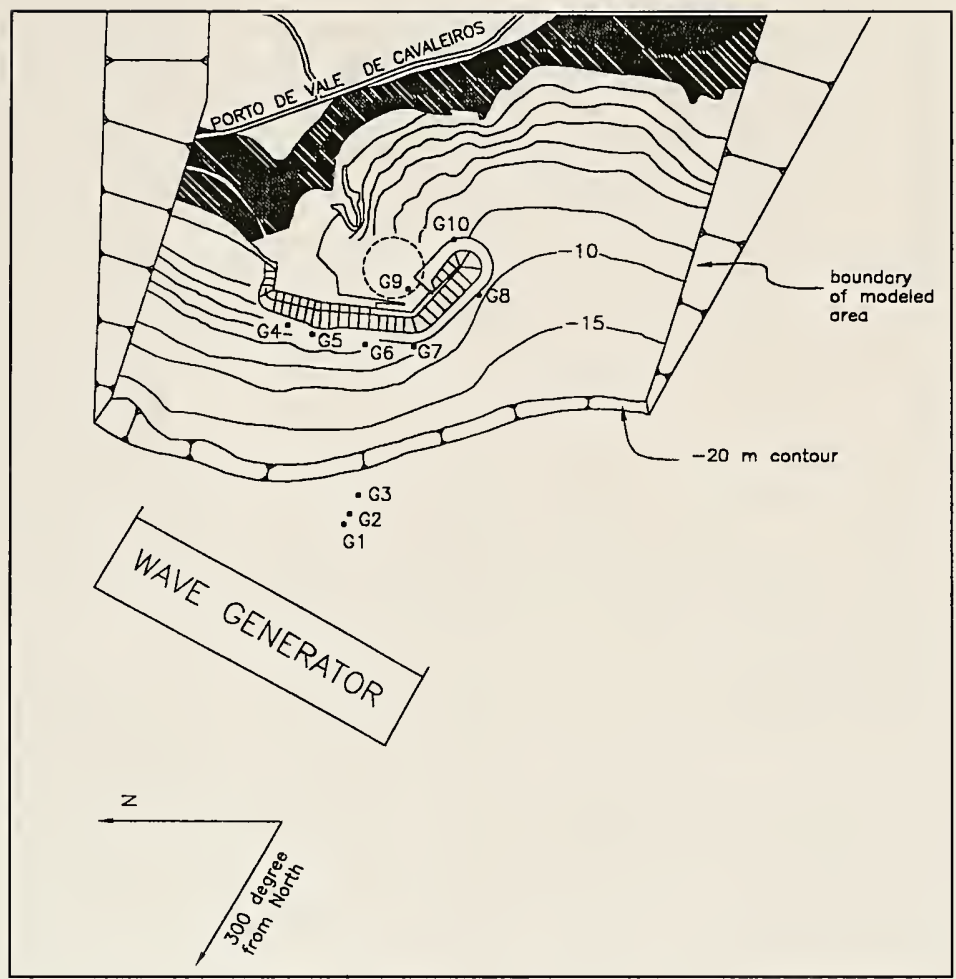

Figure 6. Three-dimensional model boundaries and wave gauge locations

The series of wave conditions selected as design storm conditions for stability experiments are shown in Table 3. The total duration of the storm was approximately $17 \mathrm{hr}$ prototype. Significant wave heights recorded at Gauge locations 4 through 10 during calibration also are shown in Table 3 . The basic breakwater configuration remained the same for Plans 1 through $1 \mathrm{C}$, but the head portion of the breakwater was raised from $+5 \mathrm{~m} \mathrm{CD}$ to $+8 \mathrm{~m}$ CD for Plans 2 through $2 \mathrm{D}$. Therefore, representative wave heights for the two breakwater configurations are given by Plan 1C and Plan 2B in Table 3. For all of the wave events conducted, critical breaking waves were produced at or near some portion of the armor toe.

\section{Experiment Procedures}

Photographs were taken before each experiment was initiated without water in the basin. Following before-test photographs, the basin was flooded to $+1.8-\mathrm{m}$ $\mathrm{CD}$ and the structure was exposed to low-level waves, $T_{p}=13 \mathrm{sec}, H_{s}^{\prime}=3.0 \mathrm{~m}$, 


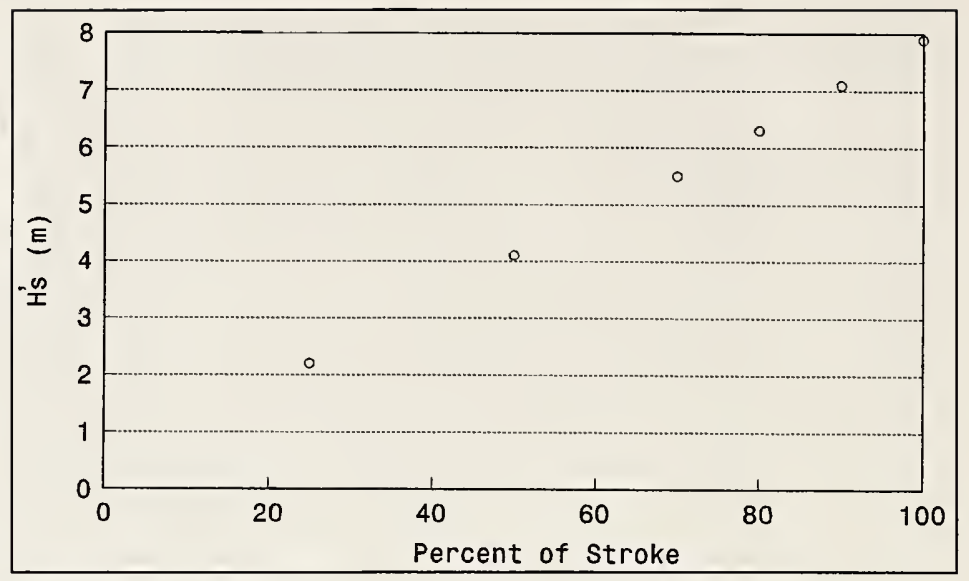

Figure 7. $H_{s}^{\prime}$ at $-21.3 \mathrm{~m}$ CD versus generator stroke, 13-sec waves

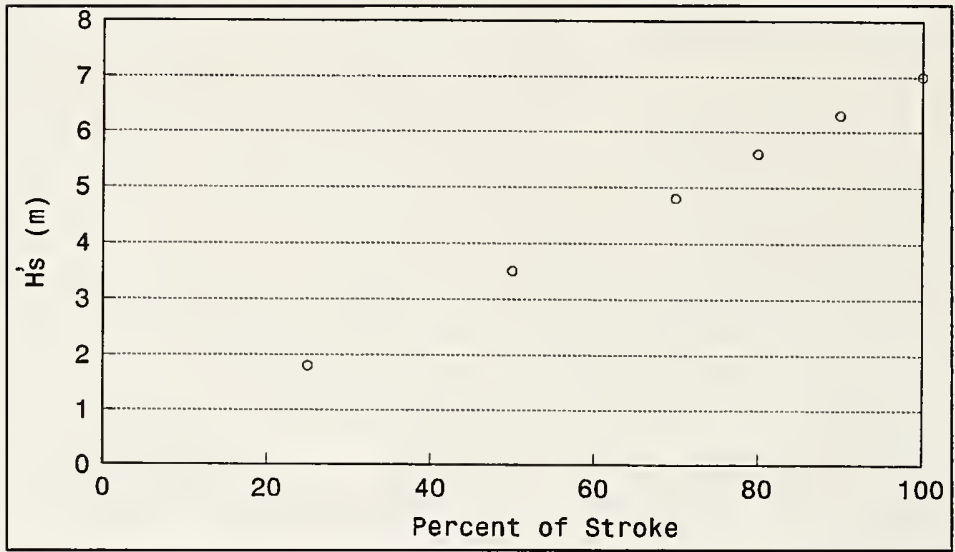

Figure 8. $H_{s}{ }^{\prime}$ at $-21.3 \mathrm{~m}$ CD versus generator stroke, 16-sec waves

wave condition 1 in Table 3 . The low-level series allowed settling and nesting of the newly constructed section which would occur under typical daily wave conditions prior to being exposed to a design-level storm, and the small motion of armor units under these conditions would not normally cause breakage of units. The remainder of the wave conditions listed in Table 3 were generated upon completion of the low-level waves beginning with $13-\mathrm{sec}, 3.7-\mathrm{m}$ waves and progressing to longer periods of constant height, i.e., 16-sec, 3.7-m and 19-sec, 3.7-m waves. Wave height was increased after all periods of a given height were completed. 


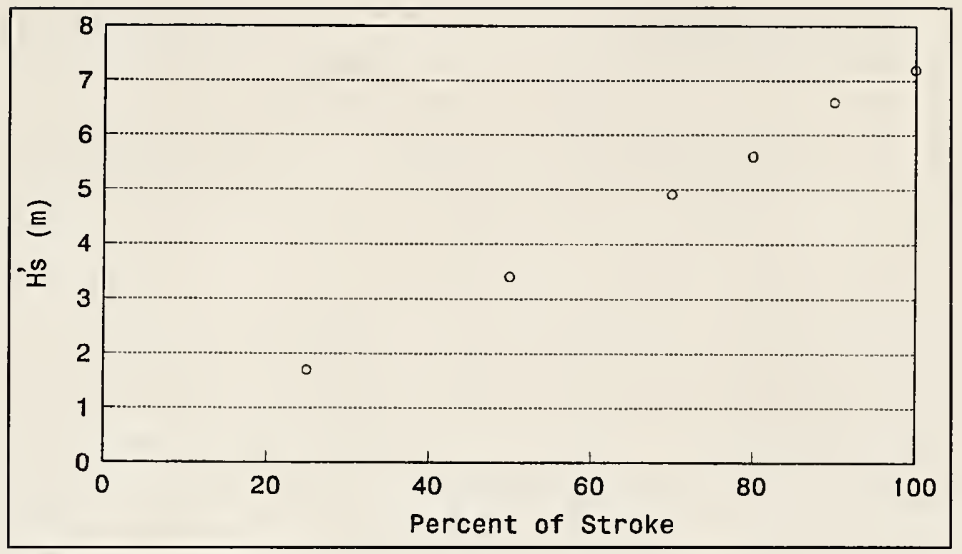

Figure 9. $\quad H_{s}^{\prime}$ at $-21.3 \mathrm{~m} \mathrm{CD}$ versus generator stroke, 19-sec waves

\begin{tabular}{|c|c|c|c|c|c|c|c|c|}
\hline \multicolumn{9}{|c|}{$\begin{array}{l}\text { Table } 3 \\
\text { Stability Study Wave Conditions }\end{array}$} \\
\hline \multirow{2}{*}{$\begin{array}{l}\text { Breakwater } \\
\text { Plan }\end{array}$} & \multirow[b]{2}{*}{$\mathrm{H}_{\mathrm{s}}{ }^{\prime}, \mathrm{m}$} & \multicolumn{7}{|c|}{$\mathrm{H}_{\mathrm{s}}$ at Gauge, $\mathrm{m}$} \\
\hline & & 4 & 5 & 6 & 7 & 8 & 9 & 10 \\
\hline \multicolumn{9}{|c|}{$T_{p}=13 \mathrm{sec}$} \\
\hline Plan 1C & 3.0 & & & $\overline{4.3}$ & 2.3 & 1.8 & 0.8 & 1.3 \\
\hline Plan 2B & 3.0 & & & 4.4 & 2.3 & 1.9 & 0.5 & 1.2 \\
\hline Calibration & 3.0 & 4.0 & 4.6 & 3.1 & 2.1 & 1.0 & & \\
\hline Plan $1 C$ & 3.7 & & & 4.8 & 2.8 & 2.4 & 0.9 & 1.6 \\
\hline Plan 2B & 3.7 & & & 4.8 & 2.7 & 2.4 & 0.6 & 1.4 \\
\hline Calibration & 3.7 & 4.5 & 4.9 & 3.7 & 2.9 & 1.2 & & \\
\hline Plan $1 C$ & 5.2 & & & 5.3 & 4.2 & 4.2 & 1.1 & 2.5 \\
\hline Plan 2B & 5.2 & & & 5.4 & 4.2 & 4.3 & 0.7 & 2.0 \\
\hline Calibration & 5.2 & 5.1 & 5.7 & 4.3 & 4.3 & 2.1 & & \\
\hline Plan $1 \mathrm{C}$ & 6.7 & & & 5.4 & 5.5 & 5.8 & 1.2 & 3.0 \\
\hline Plan 2B & 6.7 & & & 5.6 & 5.5 & 5.8 & 0.8 & 2.5 \\
\hline Calibration & 6.7 & 5.2 & 5.9 & 4.4 & 5.7 & 3.2 & & \\
\hline \multicolumn{9}{|c|}{$T_{p}=16 \mathrm{sec}$} \\
\hline Plan 1C & 3.7 & & & 4.7 & 3.6 & 3.6 & 1.0 & 2.0 \\
\hline Plan 2B & 3.7 & & & 4.7 & 3.6 & 3.6 & 0.6 & 1.6 \\
\hline Calibration & 3.7 & 4.6 & 5.2 & 4.0 & 3.4 & 1.5 & & \\
\hline
\end{tabular}




\begin{tabular}{|c|c|c|c|c|c|c|c|c|}
\hline \multicolumn{9}{|c|}{ Table 3 (Concluded) } \\
\hline \multirow{2}{*}{$\begin{array}{l}\text { Breakwater } \\
\text { Plan }\end{array}$} & \multirow[b]{2}{*}{$H_{s}{ }^{\prime}, m$} & \multicolumn{7}{|c|}{$\mathrm{H}_{\mathrm{s}}$ at Gauge, $\mathrm{m}$} \\
\hline & & 4 & 5 & 6 & 7 & 8 & 9 & 10 \\
\hline \multicolumn{9}{|c|}{$T_{p}=16 \mathrm{sec}$} \\
\hline Plan $1 \mathrm{C}$ & 5.2 & & & 5.3 & 5.3 & 5.8 & 1.2 & 2.8 \\
\hline Plan 2B & 5.2 & & & 5.3 & 5.2 & 5.7 & 0.7 & 2.3 \\
\hline Calibration & 5.2 & 5.2 & 5.8 & 4.8 & 4.6 & 2.5 & & \\
\hline Plan 1C & 6.7 & & & 5.6 & 6.5 & 7.2 & 1.3 & 3.2 \\
\hline Plan 2B & 6.7 & & & 5.7 & 6.5 & 7.3 & 0.8 & 2.7 \\
\hline Calibration & 6.7 & 5.2 & 5.9 & 5.0 & 5.9 & 4.0 & & \\
\hline \multicolumn{9}{|c|}{$T_{p}=19 \mathrm{sec}$} \\
\hline Plan 1C & 3.7 & & & 4.6 & 3.9 & 4.0 & 1.0 & 1.9 \\
\hline Plan 2B & 3.7 & & & 4.5 & 3.8 & 4.0 & 0.6 & 1.5 \\
\hline Calibration & 3.7 & 4.3 & 4.6 & 5.1 & 3.2 & 2.0 & & \\
\hline Plan 1C & 5.2 & & & 5.4 & 5.9 & 6.4 & 1.2 & 2.7 \\
\hline Plan 2B & 5.2 & & & 5.4 & 6.0 & 6.4 & 0.8 & 2.3 \\
\hline Calibration & 5.2 & 5.1 & 5.6 & 6.2 & 4.8 & 2.8 & & \\
\hline Plan 1C & 6.7 & & & 5.9 & 7.2 & 7.8 & 1.3 & 3.3 \\
\hline Plan 2B & 6.7 & & & 6.0 & 7.2 & 7.9 & 0.8 & 2.8 \\
\hline Calibration & 6.7 & 5.3 & 6.0 & 5.4 & 6.2 & 4.1 & & \\
\hline
\end{tabular}

Response of the structure was recorded during and after each wave condition. Photographs also were taken at seaside locations while the basin was flooded if significant damage to the structure occurred during a wave condition. A detailed inspection of the structure also was performed and effects of the waves on individual units, toe buttress protection, and the general condition of the structure were recorded. The basin was drained, and after-experiment photographs were taken after all waves of the storm series were generated or the structure had suffered significant damage. Before and after photographs are located in Appendix A.

\section{Model Breakwater Construction}

Construction of the modeled section simulated prototype construction as closely as possible. The core, bedding, and underlayer of material were dumped by shovel, smoothed to grade, and compacted with hand trowels to simulate consolidation that would have occurred due to wave action.

The various model plans consisted of 8- and/or 11-tonne Core-Locs placed in the armor layer from Profile 4 to the breakwater head, and 6.25-tonne tetrapods 
placed between Profiles 1 and 3. Core-Locs were placed according to the method given by Melby and Turk (1995).

The number of Core-Loc units placed on the breakwater, or density of units, was based on the equation:

$$
\frac{N}{A}=\phi V^{-\frac{2}{3}}
$$

where $N$ is the number of units in a given area, $A$ is the section area, $V$ is the armor unit volume, $\phi$ is the packing density coefficient which is dependent upon armor layer thickness and armor layer porosity. Armor layer thickness is equal to about 0.92 of the respective Core-Loc leg length and the average armor layer porosity is about 60 percent. Core-Loc is a relatively new armor unit and tests are ongoing to determine optimal and constructable placement density of the units. For this stability study, $\phi$ was purposely unspecified so that each model armor placement would be a natural coverage and not exceed prototype construction limitations. For the tests conducted, $\phi$ ranged from 0.55 to 0.63 depending on the base area covered and variance due to the random nature of the packing.

\section{Reporting Model Observations}

Visual inspections were made during and after wave action on the structure. Because Core-Locs are placed in one layer, less than 2 percent displacement by unit count was desired. 


\section{Results}

\section{Introduction}

Three-dimensional stability experiments were conducted for nine configurations at a model scale of 1:48.4. The configurations consisted of two basic breakwater plans. Plan 1 and Plan 2 differed in that Plan 1 consisted of 8- and 11-tonne Core-Locs and a crest elevation of $+5 \mathrm{~m} \mathrm{CD}$ at the head section, whereas Plan 2 was armored entirely with 11-tonne Core-Locs and had a head section elevation of $+8 \mathrm{~m} \mathrm{CD}$. Four toe protection schemes were studied using the Plan 1 configuration, and five toe configurations were used with Plan 2.

\section{Plan 1}

Plan 1, the initial plan (Figure 10, Photos A1 through A3), consisted of 6.25-tonne tetrapods from the shoreward end of the breakwater to Profile 4; 8-tonne Core-Locs from Profile 4 to a point between Profiles 6 and 7 (a total reach of approximately $92 \mathrm{~m}$ ); and 11-tonne Core-Locs on the remainder of the seaward trunk, around the head and terminating at the quay wall on the leeward side of the structure. For this plan, packing densities of the 8- and 11-tonne Core-Loc reaches were 0.55 and 0.59 , respectively. The crest elevation of the head section was $+5 \mathrm{~m}$ CD. Plan 1 was subjected to "shakedown" waves (13 sec, $3 \mathrm{~m}$ ) to settle and nestle the armor units. During the wave series, apron material was displaced between Profiles 4 and 9, and Core-Locs were displaced at the toe near Profile 4 (Photos A4 through A6). The structure was subjected to 3.7-m waves for 13- and 16-sec periods, which caused additional toe unit displacement at Profile 4 and at the elbow near Profile 8.

\section{Plan 1A}

Plan 1A was the same as Plan 1 except a toe buttress was constructed of stone of identical weight as the underlayer stone ( 0.75 to 1.8 tonne) and placed between Profile 4 and the terminus of the quay wall near Profile 10 (Photos A7 through A9). The buttress was placed two stones high and three stones wide 


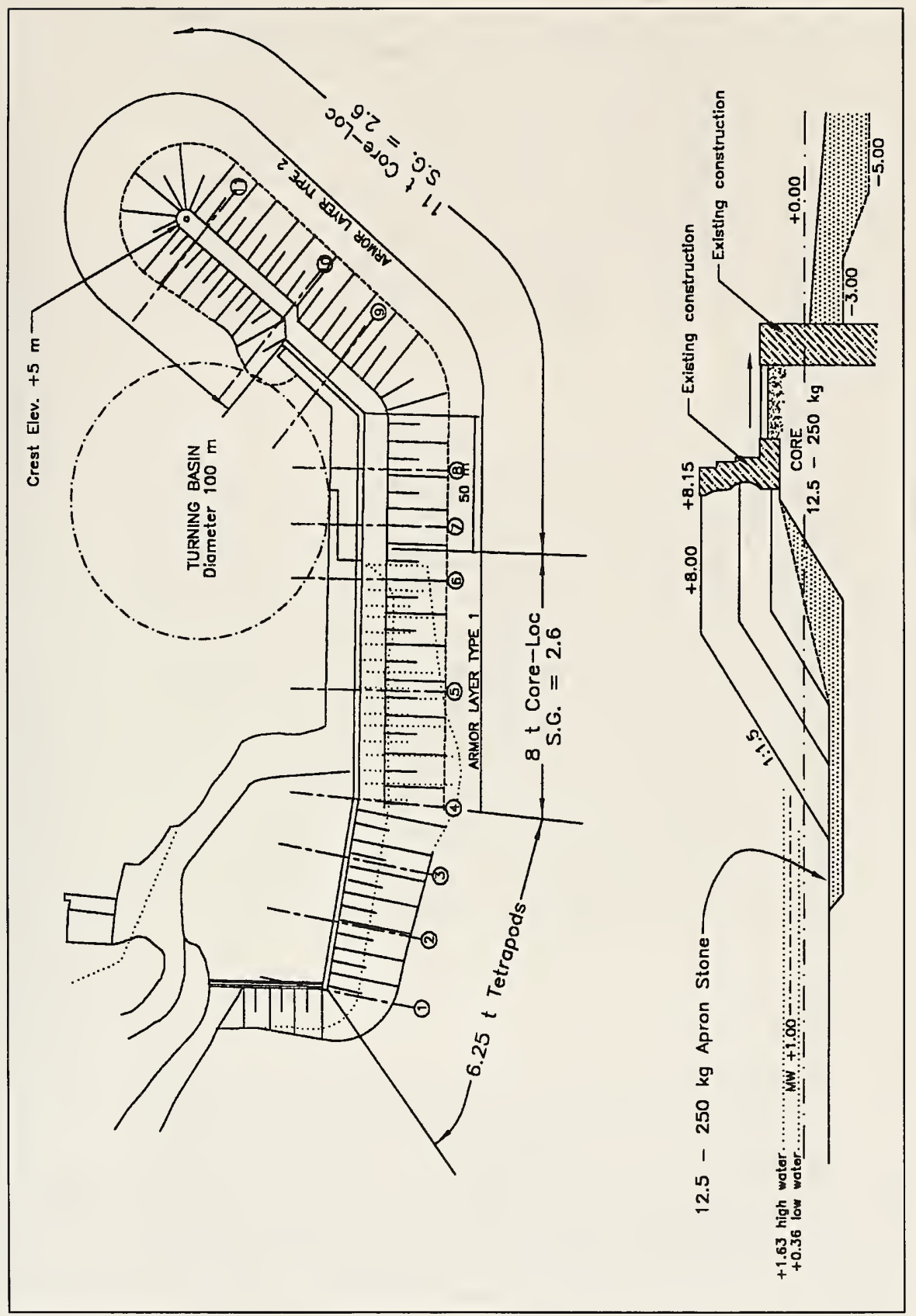

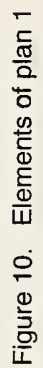


(Figure 11). The 8-tonne Core-Loc armor layer was rebuilt resulting in a packing density of 0.60 . The buttress material was displaced between Profiles 4 and 5 and between Profile 8 and the elbow of the structure during 13-sec, 3-m waves. Core-Locs in the vicinity of Profile 4 began to slide seaward, but the structure remained stable. However, the buttress was removed during $13-\mathrm{sec}, 3.7-\mathrm{m}$ waves between Profiles 4 and 6 and toe units in this region began to move. Eight-tonne units were displaced between Profiles 4 and 5 during 16-sec, 3.7-m waves and a hole developed at the crest near Profile 4 (Photo A10). The larger units, 11 tonnes, remained stable during Plan 1A tests (Photos A11 and A12). It was noted that the steep approach slope and the shallow depth in this region produced breaking waves that plunged along the toe region. The plunging breakers caused apron material to erode and forced the toe Core-Locs away from the structure.

\section{Plan 1B}

Plan 1B was identical to Plan 1 except three widths of bundled steel chain were placed along the toe from Profile 4 to the elbow (Figure 12). A single chain was placed at the toe at the elbow to the terminus of the quay wall. Additionally, a single chain was placed around the toe of the tetrapod section. The purpose of the chain was to stabilize the toe to observe the stability of upslope units. Rebuilding of the 8-tonne Core-Loc section resulted in $\phi=0.60$. The addition of the chain stabilized the Core-Locs at the toe; however, wave energy also displaced the chain and it was necessary to reposition the chain between wave series. The armor layer loosened between Profiles 4 and 5, and apron material was displaced for wave conditions up to $17-\mathrm{sec}, 5.2-\mathrm{m}$, but the section remained stable (Photo A13). During the 17-sec, 5.2-m condition, 11-tonne units at the toe near Profile 10, which was unprotected by the chain, were removed by waves, causing the upper units in this area to be displaced. A hole developed in the armor layer near the crown at Profile 10, which increased in size and migrated "north" along the structure (Photos A14 through A16). Additionally, green water overtopping was observed over the $+5-\mathrm{m}$ CD breakwater section for waves $3.7 \mathrm{~m}$ in height and greater. The severe breaking condition migrated to deeper water as peak period and/or wave height increased.

\section{Plan 1C}

Plan 1C was the same as Plan 1B except three widths of steel chain were included along the toe from Profile 4 to the leeward side of Profile 11 for Plan 1C (Figure 12). In addition, the chain was anchored to the breakwater at approximately 8-m (prototype) intervals using pins inserted under the structure. The breakwater was rebuilt prior to experiments and the resulting packing densities for the 8 - and 11 -tonne Core-Locs were 0.62 and 0.59 , respectively. The structure was stable for waves up to $6.7 \mathrm{~m}$, but it was observed that the armor layer loosened in areas between chain anchors. During 16-sec, 6.7-m waves, one 


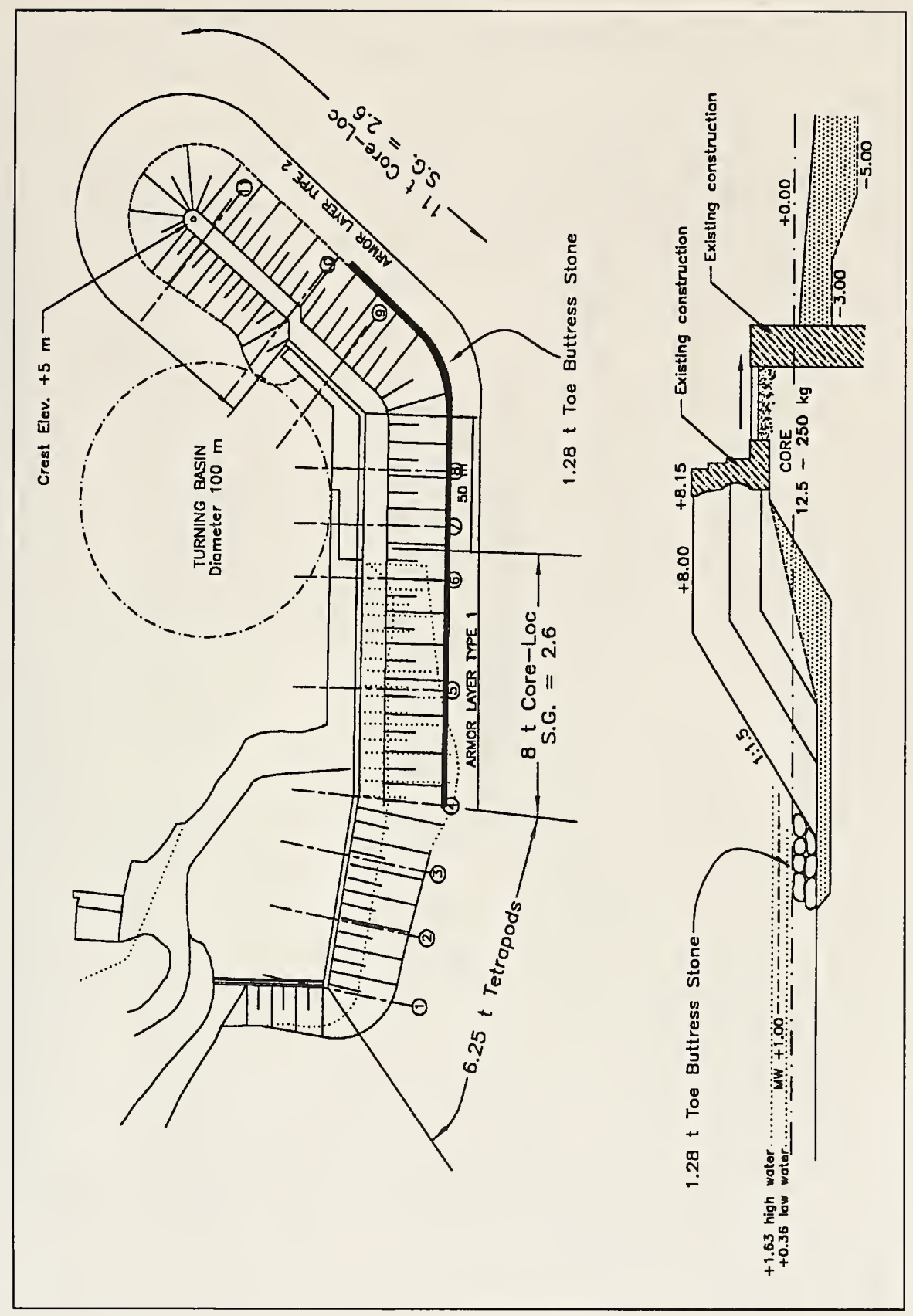

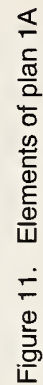




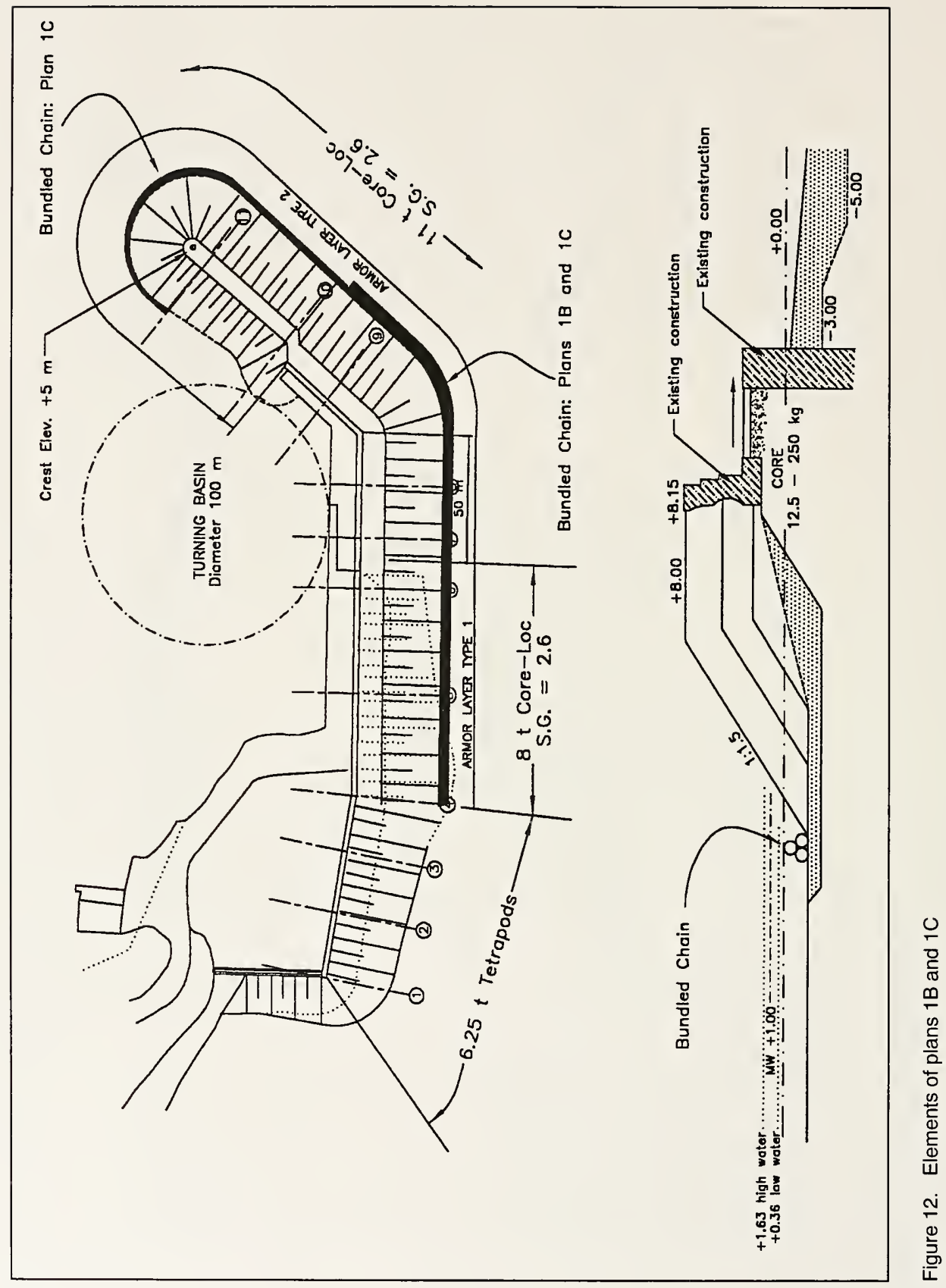


11-tonne and three 8-tonne toe units were displaced. The toe failed near Profile 10 during 19-sec, 6.7-m waves at a location where the chain was forced seaward between anchors (Photos A17 through A19).

Plan 1C was rebuilt and repeated with additional pins used to anchor the chain to the structure. Packing densities remained the same as the original Plan 1C. The plan was subjected to the entire storm series and was moderately stable. Three 8-tonne units were displaced between Profiles 4 and 5, and two 11-tonne units were displaced between Profiles 9 and 10 (Photos A20 through A22). All displaced units originated at the toe.

\section{Plan 2}

Based on observations of the model and conversations with JV RRI-BCEOM personnel Messrs. A. Merrien and L. Fischer, Plan 2 consisted of raising the $+5-\mathrm{m}$ head portion of the breakwater to bring the entire structure to $+8 \mathrm{~m}$ to reduce overtopping. The 8 -tonne units were replaced with 11-tonne Core-Locs and the toe was reinforced with additional 11-tonne units placed in a single row (Figure 13). The packing density of the 11-tonne Core-Locs was 0.62. Toe protection units were placed $90 \mathrm{deg}$ to the toe units of the structure in a manner in which adjacent units interlocked (Photos A23 through A25). The 11-tonne CoreLocs used for toe protection were displaced during 13- and 16-sec, 3.7-m waves, and the armor layer failed due to toe instability (Photos A26 and A27).

\section{Plan 2A}

Plan 2A was the same as Plan 2 except the single row of 11-tonne Core-Locs was replaced with a wood board anchored to the floor around the entire CoreLoc armor layer to act as an immovable toe restraint. The board simulated a toe trench $1 \mathrm{~m}$ deep and included a 45-deg bevel adjacent to the toe unit (Figure 14). The plan consisted entirely of 11-tonne Core-Locs $(\phi=0.61)$ beginning at Profile 4 with a crest elevation of $+8 \mathrm{~m}$ CD throughout the structure (Photos A28 through A30). One toe unit was displaced during 16-sec, 3.7-m waves near Profile 5, but the structure was stable for waves up to $16-\mathrm{sec}, 5.2-\mathrm{m}$ waves. During the 16-sec, 5.2-m condition, one toe unit was displaced near Profile 6, one toe unit was displaced from Profile 9, and three toe units were displaced near Profile 10. No further displacement of Core-Locs was observed for 19-sec, 5.2-m or 13-sec, 6.7-m waves; however, underlayer stone was observed to be displaced between Profiles 4 and 6 in areas of toe displacement. Additionally, the armor layer began to loosen in this area. During 16-sec, 6.7-m waves, 16 additional toe units were displaced, producing noticeable damage to the structure. Most of the armor was displaced off the structure at the elbow between Profiles 8 and 9 during 19-sec, 6.7-m waves (Photos A31 through A33). 


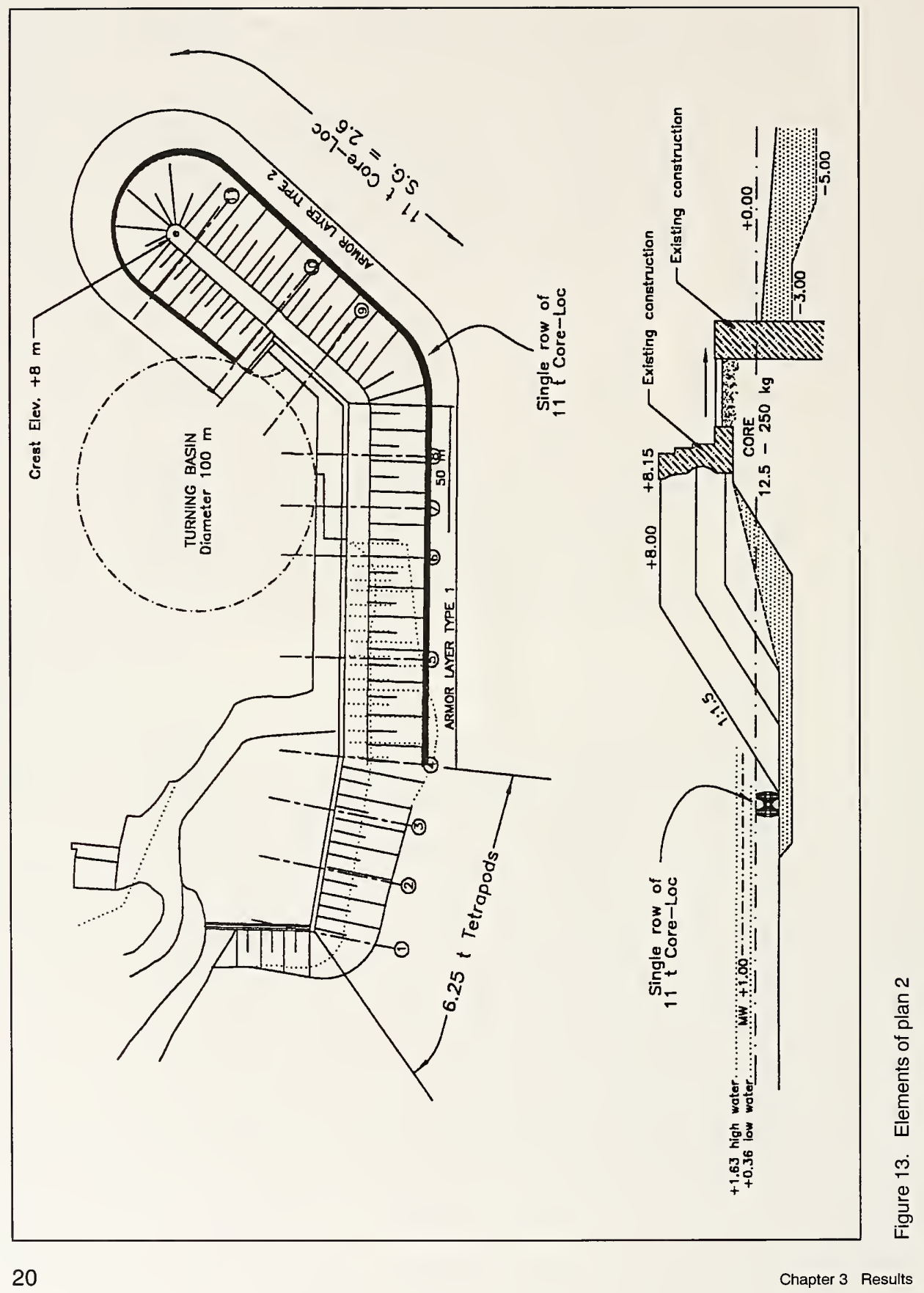




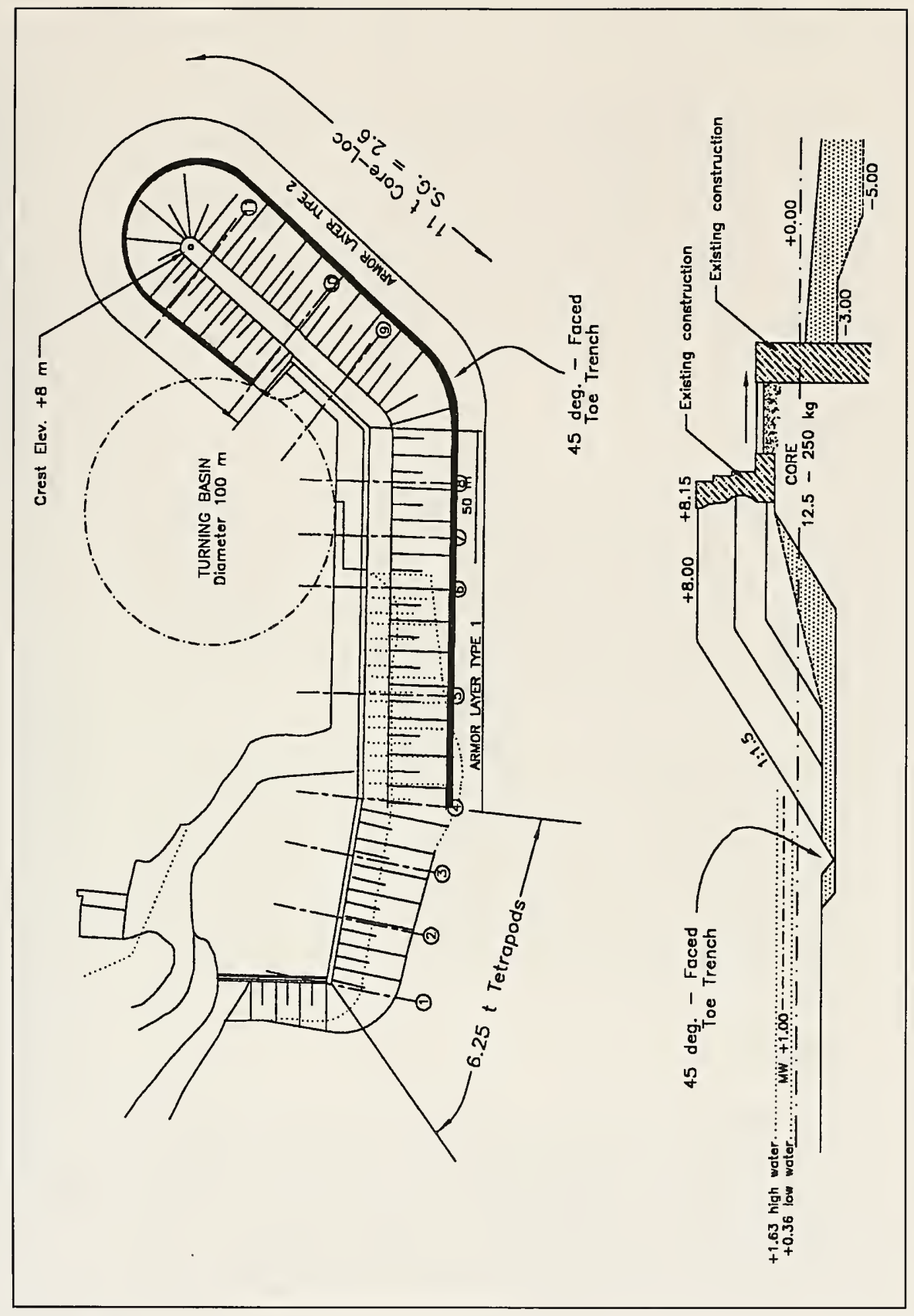

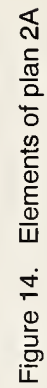




\section{Plan 2B}

Plan 2B was identical to plan 2A except the toe reinforcement was constructed using a board anchored to the floor to represent a toe trench $1.5 \mathrm{~m}$ high with vertical sides (Figure 15). The breakwater armor was rebuilt and the packing density for the 11-tonne Core-Locs was 0.63 . To expedite the study, all 3.7-m waves and the $13-\mathrm{sec}, 5.2-\mathrm{m}$ condition were omitted for this test series. From previous experiments with plans which included a restrained toe, the omitted wave conditions caused no or only minor damage to the breakwater. No units were displaced during this series (Photos A34 through A36). Plan 2B was rebuilt with the same packing density and the experiment was repeated. One Core-Loc was displaced off the head midway through 19-sec, 6.7-m waves, but the structure remained stable throughout the rest of the wave condition.

\section{Plan 2C}

The breakwater was rebuilt entirely of 11-tonne Core-Locs $(\phi=0.63)$, but the board used to simulate a toe trench was removed between Profile 4 to a location $70 \mathrm{~m}$ from the elbow (Figure 16, Photos A37 through A39). Model concrete blocks were placed in this area to simulate 6.1 -m-long, 2.5 -m-wide, $1.2-\mathrm{m}$-high cargo containers filled with concrete. The containers had an approximate prototype weight of 42.4 tonnes using a concrete specific gravity of 2.3 in the prototype. The containers were placed $1 \mathrm{~m}$ apart along the toe and 11-tonne Core-Locs were placed against the containers.

The structure was subjected to all waves listed in Table 3. The containers began to displace during 13-sec, 3.0-m waves and movement of containers increased as wave height increased. However, the containers provided some sheltering and prevented unraveling of the Core-Loc toe up to 3.7-m waves for all three periods. Waves higher than $3.7 \mathrm{~m}$ for all periods displaced the containers out of the section and moved them southward along the toe and around the elbow to the head (Photos A40 through A42). After the containers were displaced from the original section, toe units in the area were displaced and upslope units slipped, causing significant exposure of the underlayer stone between Profiles 4 and 5 (Photo A40).

\section{Plan 2D}

Plan 2D was identical to Plan 2C except the cargo containers were placed end to end along the Core-Loc toe (Figure 16, Photos A43 and A44). The armor layer was rebuilt with a packing density of 0.62 . Results were similar to experiments with Plan $2 \mathrm{C}$; the containers began to displace during $13-\mathrm{sec}, 3.0-\mathrm{m}$ waves and movement continued with higher waves. Eventually, all containers were displaced from their original position and moved southward along the breakwater. Without toe protection, Core-Loc toe units were displaced and upslope 


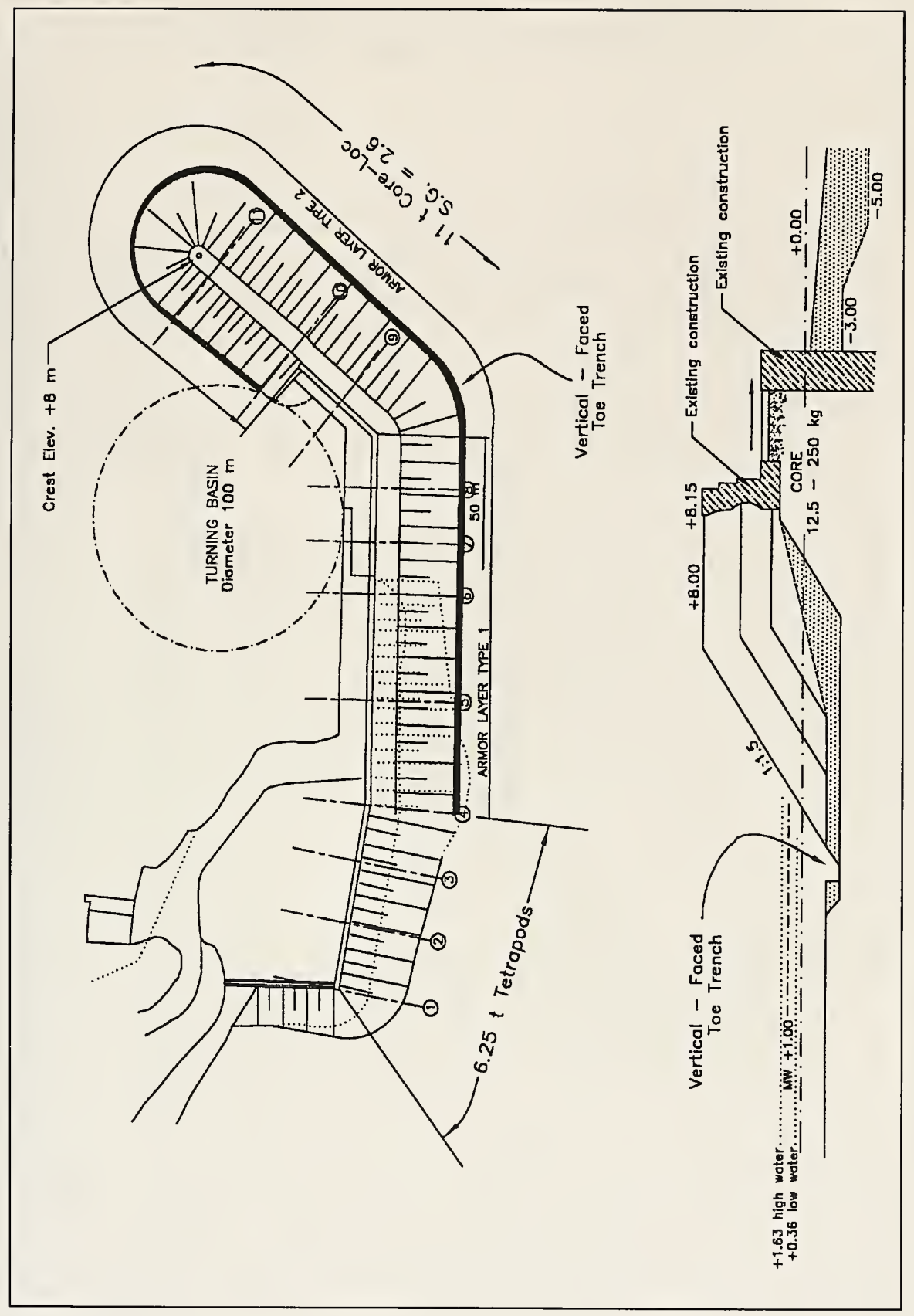

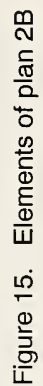



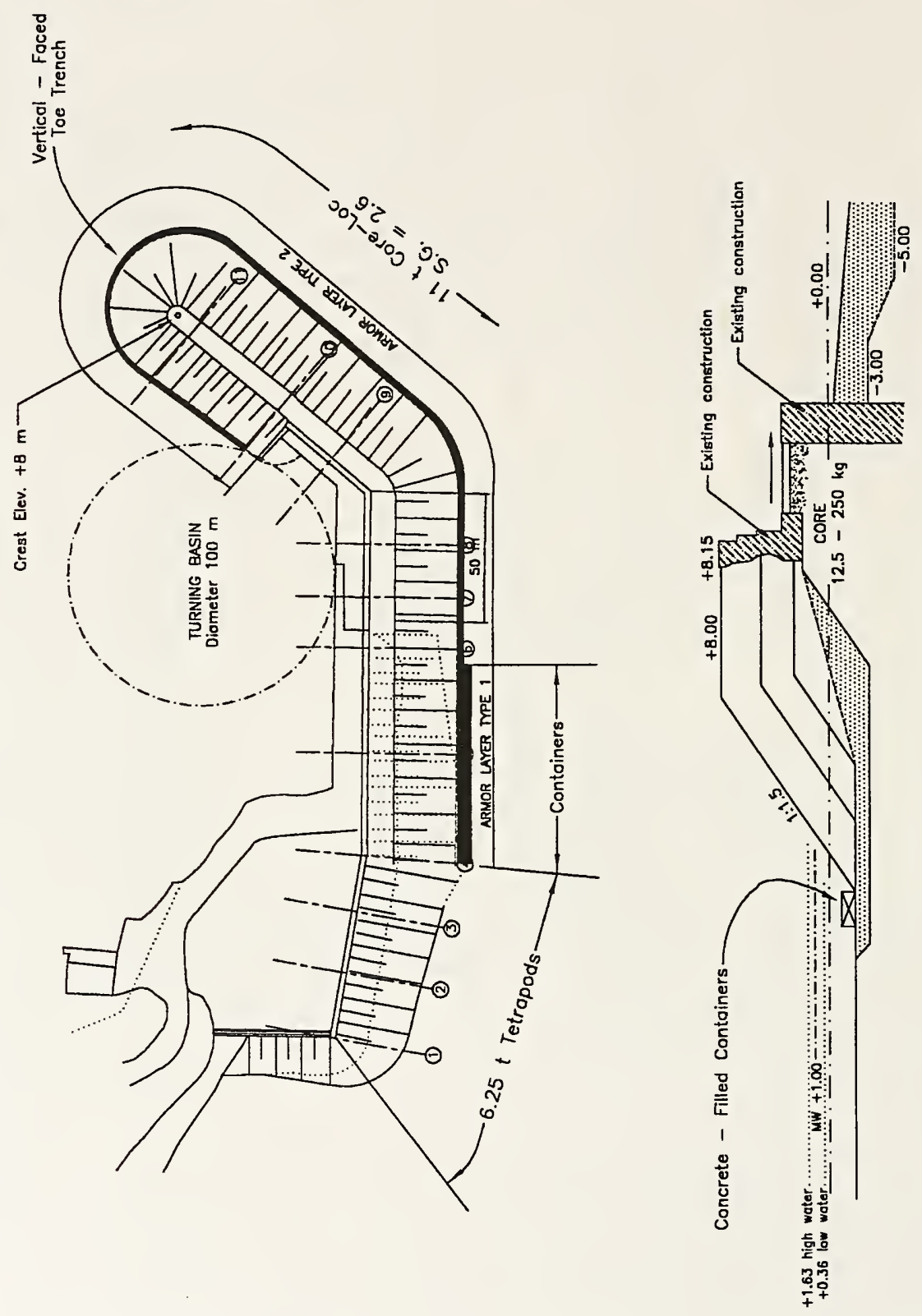

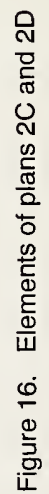


units settled causing exposure of underlayer stone between Profiles 4 and 5 (Photos A45 and A46).

\section{Overtopping}

Observations during the experiments showed that overtopping was essentially the same for Plans 1 through $1 \mathrm{C}$ and for Plans 2 through 2D, because only the toe stability configuration differed between plans. All Plan 1 series experiments were conducted with 8- and 11-tonne Core-Locs, and the head portion of the breakwater was $+5 \mathrm{~m}$ CD. The Plan 2 series of experiments consisted of all 11-tonne Core-Locs and the head portion of the breakwater was $+8 \mathrm{~m} \mathrm{CD}$.

Overtopping was classified as minor, moderate, or major. Minor overtopping was defined for the present study as occasional or no overtopping. Moderate overtopping was defined as regular overtopping with occasional green water. Conditions that produced frequent overtopping and green water were classified as major.

The classification of overtopping (minor, moderate, or major) is plotted versus wave condition in Figures 17 through 19. The wave conditions in the figures are labeled from left to right by the sequence in which they were generated during the experiment, i.e., $13-\mathrm{sec}, 3.0-\mathrm{m}$ waves were generated first and 19 -sec, 6.7-m waves were generated last. Figure 17 shows the amount of overtopping that occurred at the trunk for all plans. Major overtopping occurred at the trunk for $16-\mathrm{sec}, 6.7-\mathrm{m}$ waves, but was minor or moderate for all other conditions. Figures 18 and 19 show overtopping classifications for Plan 1 and Plan 2 series experiments at the head, respectively. The figures illustrate the reduction of overtopping by raising the crest elevation to $+8 \mathrm{~m} \mathrm{CD}$ (Plan 2 series) from $+5 \mathrm{~m}$ CD (Plan 1 series).

\section{Summary}

Stability plans tested are summarized in Table 4. Based on experiments conducted on the three-dimensional model of Vale de Cavaleiros breakwater, 11-tonne Core-Locs are stable on the structure if the toe is stable. It was necessary in the model to simulate a trench having a near vertical face and a depth of $1.5 \mathrm{~m}$. No reduction in stability was observed by raising the $+5-\mathrm{m} \mathrm{CD}$ portion of the breakwater to $+8 \mathrm{~m} \mathrm{CD}$. 


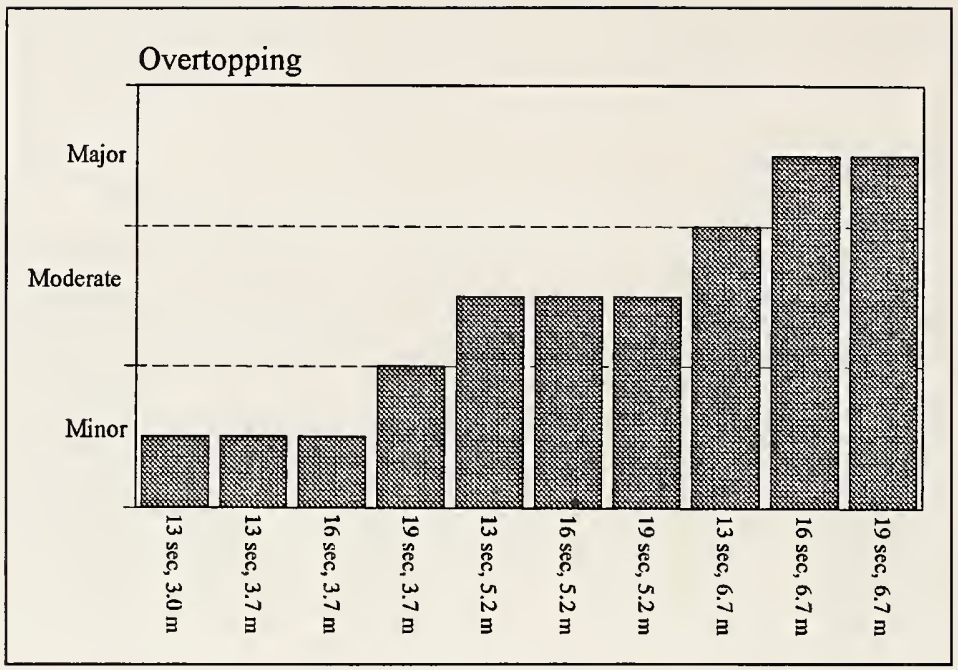

Figure 17. Wave overtopping at trunk, all plans

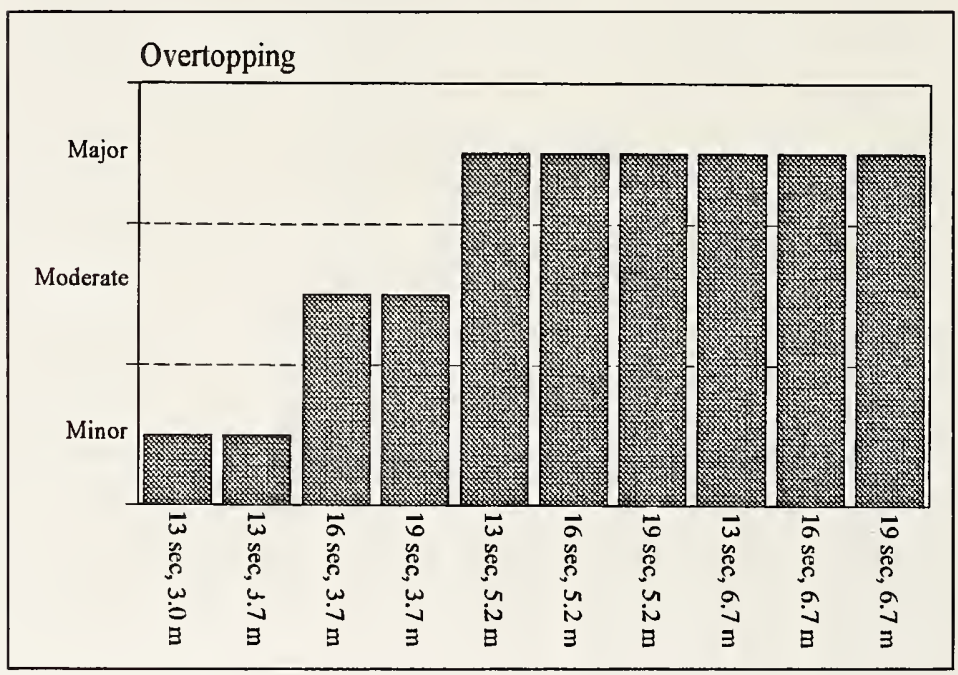

Figure 18. Wave overtopping at breakwater head, plan 1 series waves 


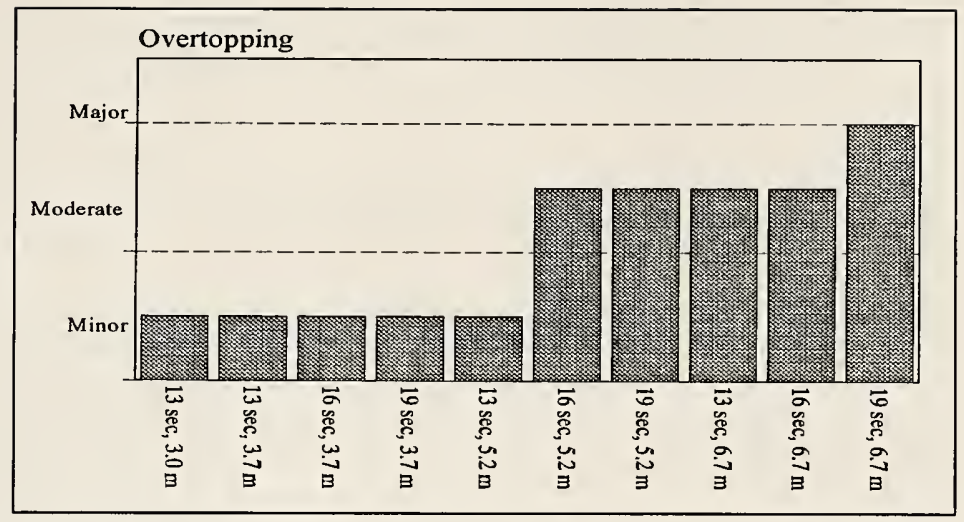

Figure 19. Wave overtopping at breakwater head, plan 2 series waves

\begin{tabular}{|c|c|c|c|}
\hline \multicolumn{4}{|c|}{$\begin{array}{l}\text { Table } 4 \\
\text { Summary of Stability Experiments }\end{array}$} \\
\hline Plan & Main Features & Figure & $\overline{\text { Photos }}$ \\
\hline 1 & $\begin{array}{l}\text { Initial Plan } \\
\text { Profiles } 1 \text { - 4: } 6.25 \text {-tonne Tetrapods } \\
\text { Profiles } 4 \text { - 6/7: } 8 \text {-tonne Core-Locs } \\
\text { Profiles } 6 / 7 \text { to head: } 11 \text {-tonne Core-Locs } \\
\text { Crest: }+5 \mathrm{~m} \text { CD south of elbow } \\
\text { Packing density }(\phi): \\
\text { 8-tonne Core-Locs }-0.55 \\
\text { 11-tonne Core-Locs }-0.59\end{array}$ & 10 & A1 through $A 6$ \\
\hline $1 \mathrm{~A}$ & $\begin{array}{l}\text { Same as Plan } 1 \text { except: } \\
\text { Profiles } 4 \text { through } 10 \text { : } \\
\text { Toe Protection: buttress of } 0.75 \text { - to } 1.8 \text {-tonne stone } \\
\phi=0.60 \text { (8-tonne Core-Locs) }\end{array}$ & 11 & A7 through $\mathrm{A} 12$ \\
\hline $1 \mathrm{~B}$ & $\begin{array}{l}\text { Same as Plan } 1 \text { except: } \\
\text { Toe Protection: chain (Profile } 4 \text { to elbow) }\end{array}$ & 12 & A13 through $A 16$ \\
\hline $1 \mathrm{C}$ & $\begin{array}{l}\text { Same as Plan 1B except: } \\
\text { Toe Protection: anchored chain (Profiles } 4 \text { to 11) } \\
\phi=0.62 \text { (8-tonne Core-Locs) }\end{array}$ & 12 & A17 through A22 \\
\hline 2 & $\begin{array}{l}\text { Same as Plan } 1 \mathrm{C} \text { except: } \\
\text { Crest elevation raised from }+5 \mathrm{~m} \text { CD to }+8 \mathrm{~m} \text { CD } \\
11 \text {-tonne Core-Locs used on entire structure } \\
\text { Toe Protection: Single row of } 11 \text {-tonne Core-Locs } \\
\phi=0.62\end{array}$ & 13 & A23 through A27 \\
\hline $2 A$ & $\begin{array}{l}\text { Same as Plan } 2 \text { except: } \\
\text { Toe Protection: Toe trench with 45-deg bevel } \\
\phi=0.61\end{array}$ & 14 & A28 through A33 \\
\hline $2 \mathrm{~B}$ & $\begin{array}{l}\text { Same as Plan } 2 A \text { except: } \\
\text { Toe Protection: Toe trench with vertical face } \\
\phi=0.63\end{array}$ & 15 & A34 through A36 \\
\hline $2 \mathrm{C}$ & $\begin{array}{l}\text { Same as Plan 2A except: } \\
\text { Toe protection: Concrete-filled containers spaced } \\
1 \mathrm{~m} \text { apart (Profile } 4 \text { to } 70 \mathrm{~m} \text { north of elbow) }\end{array}$ & 16 & A37 through $\mathrm{A} 42$ \\
\hline $2 \mathrm{D}$ & $\begin{array}{l}\text { Same as Plan } 2 \mathrm{C} \text { except: } \\
\text { Toe protection: Containers spaced end to end } \\
\phi=0.62\end{array}$ & 16 & A43 through A46 \\
\hline
\end{tabular}




\section{Risk Considerations}

\section{Wave Conditions}

The sponsor-predicted return period of the higher waves generated on the model was 50 years, i.e., the storm event is predicted to occur only once every 50 years. Experiments conducted on the model showed that the design waves were depth-limited and broke seaward of the structure. Therefore, it was concluded that waves exceeding the design condition would also break seaward of the structure and would not increase damage.

The most severe storms approach the site from the northwest and stability experiments were performed only from this direction. However, the structure also is subjected to southern swell; therefore, the entire structure, including the head section, should use 11-tonne armor units and the same toe protection scheme as the breakwater trunk.

\section{Armor Unit Selection}

The Core-Loc, a recently developed armor unit (Melby and Turk 1995), was selected for use in the armor layer for the rehabilitation. Construction of the Port Saint Francis breakwater in South Africa and experiments by Smith and Hennington (1995), and Smith (1996) have shown the Core-Loc is reliable and an improvement to the Accropode, which is an armor unit that has been used extensively and successfully for 20 years worldwide. Features of the Core-Loc included improved stability to the Accropode by increasing the porosity of the armor layer; no tendency for units to rock on slope; reserve stability for wave conditions exceeding the design event; hydraulic stability when placed as a repair with other armor shapes (in Vale de Cavaleiros, some tetrapod units will remain in the northern part of the jetty); and low internal stresses. The Core-Loc is presently the most efficient armor unit for rubble-mound breakwaters, because of these properties

Displaced armor units were counted after each wave series to assess the reliability of breakwater protection. Several units were displaced during the initial plans, but only one Core-Loc was displaced over the entire breakwater for 
the final plan, Plan 2B, which included a 1.5-m-high toe trench. One displaced unit is low and does not indicate any endangerment to the structure. 


\section{Summary}

A three-dimensional physical model study was conducted to test stability of the proposed breakwater rehabilitation at Vale de Cavaleiros. The direction of storm waves was $300 \mathrm{deg}$ from the north. The series of waves generated on the model was equivalent to a $17-\mathrm{hr}$ storm prototype. The storms initiated with moderate waves of $3 \mathrm{~m}$ and were incrementally increased in height up to a depthlimited height of $6.7 \mathrm{~m}$.

\section{Results}

Results of the model study indicated:

a. The armor units selected for the original design were stable if the toe was stable. Plan 1C, which included 8- and 11-tonne Core-Locs, and bundled steel chain to anchor the breakwater toe, was stable during original and repeat tests. However, it was noted that the 8-tonne units rocked in place during tests and were considered moderately stable. Subsequent tests included 11-tonne Core-Locs on the entire structure, but a constructable prototype toe anchor was still required.

b. Plans $2 \mathrm{~A}$ and $2 \mathrm{~B}$ included a board anchored to the model floor at the base of the breakwater to stabilize the toe. Analogous results would be expected if a toe trench was used to fix the toe. The board used in Plan $2 \mathrm{~A}$ was $1 \mathrm{~m}$ deep and included a $45-\mathrm{deg}$ angle adjacent to the toe units. The sloped trench was stable for waves up to $16 \mathrm{sec}, 5.2 \mathrm{~m}$ but significant damage occurred between Profiles 8 and 9 for $16-\mathrm{sec}, 6.7-\mathrm{m}$ waves. The trench simulated in Plan $2 \mathrm{~B}$ was $1.5 \mathrm{~m}$ high and had a vertical face. Plan 2B was stable for original and repeat tests; one unit was displaced during the repeat tests, but the structure remained stable.

c. Different toe reinforcement schemes such as a stone buttress of 0.75 - to 1.8-tonne stone (Plan 1A), 11-tonne Core-Locs (Plan 2) placed at the toe, and concrete-filled cargo containers (Plans 2C and 2D) placed at the toe were tested, but were unsuccessful in stabilizing the toe. 
Results from the three-dimensional stability tests indicated the most stable plan was Plan 2B, which consisted entirely of 11-tonne Core-Locs, a constant crest elevation of $+8 \mathrm{~m} \mathrm{CD}$, and a vertical-face toe trench $1.5 \mathrm{~m}$ high.

\section{Toe Trench Construction}

For the conditions tested in the model, the breakwater was not damaged if a stable toe trench, $1.5 \mathrm{~m}$ deep and near vertical, was installed. The model tests were conducted on a fixed bottom, which in nature would be analogous to a smooth rocky bottom in the prototype. An example of a prototype toe trench constructed in a rocky bottom is shown in Figure 20. The seaward face of the trench should be as near vertical as possible.

No model tests were conducted on stability with a movable bed; therefore, it was not possible to quantify the effects of a sandy bottom on the stability of the toe trench because the model floor was fixed. For structures placed in shallow water the Shore Protection Manual (1984) recommends a toe protection scheme similar to Figure 21, in which a wide trench is constructed and replaced with armor. The Shore Protection Manual suggests constructing the trench horizontally 2 times the water depth or 2 to 3 times the design wave height for the most severe scour.

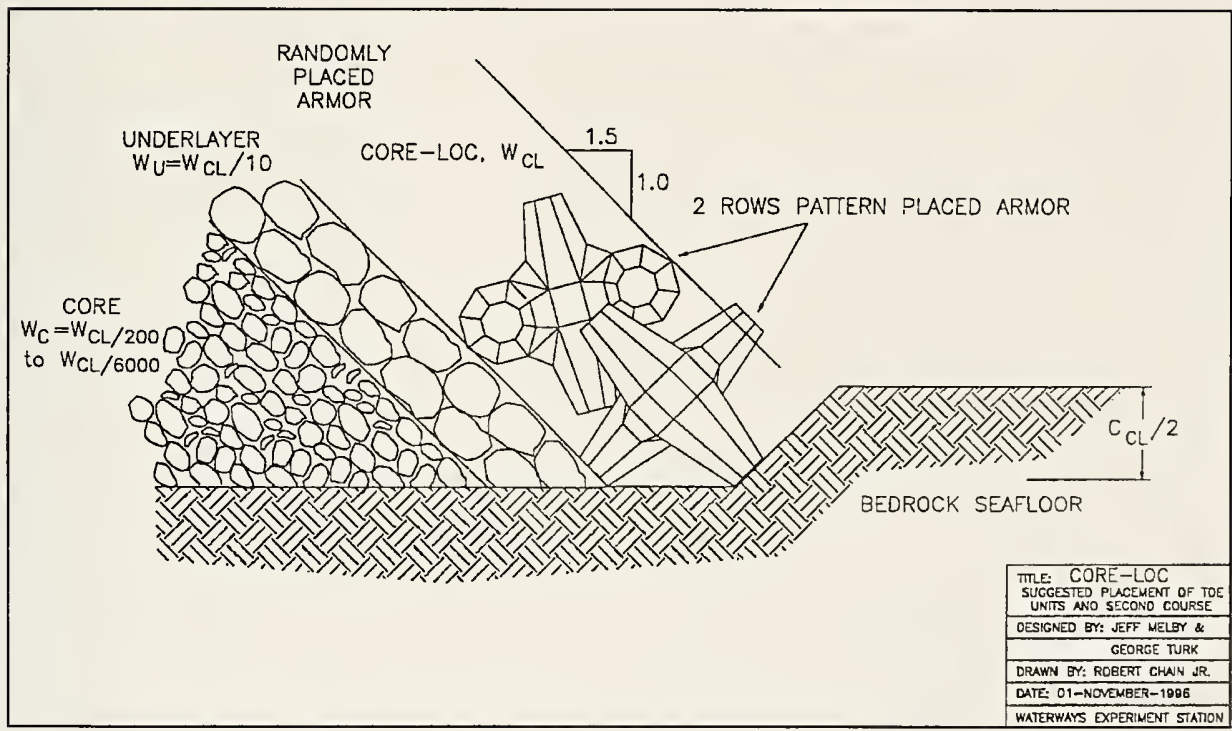

Figure 20. Example of toe trench constructed on rocky bottom 


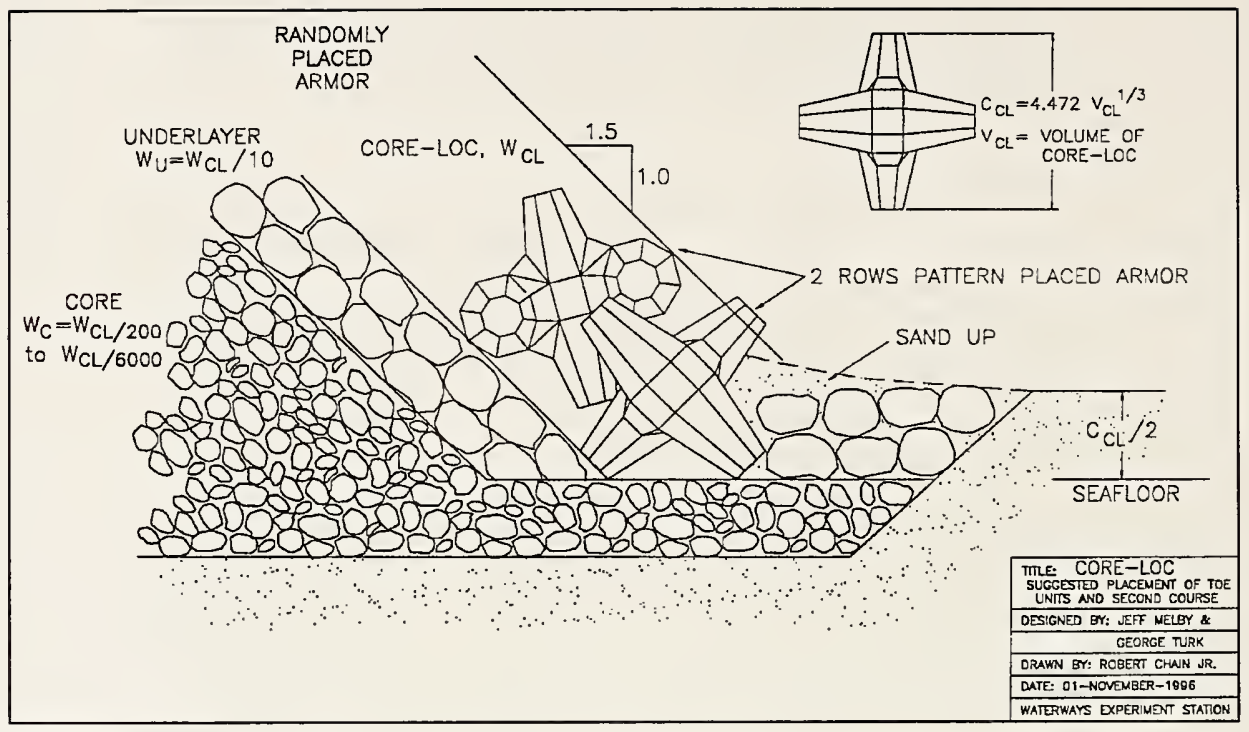

Figure 21. Example of toe trench constructed on sandy bottom 


\section{References}

Goda, T., and Suzuki, Y. (1976). "Estimation of incident and reflected waves in random wave experiments," Proceedings of the 15th Coastal Engineering Conference, American Society of Civil Engineers, Honolulu, HI, pp 828-845.

Hudson, R. Y. (1975). "Reliability of rubble-mound breakwater stability models," Miscellaneous Paper H-75-5, U.S. Army Engineer Waterways Experiment Station, Vicksburg, MS.

Hughes, S. A. (1984). "The TMA shallow-water spectrum description and applications," Technical Report CERC-84-7, U.S. Army Engineer Waterways Experiment Station, Vicksburg, MS.

Long, C. E., and Ward, D. L. (1987). "Time series analysis," unpublished computer program, U.S. Army Engineer Waterways Experiment Station, Vicksburg, MS.

Melby, J. A., and Turk, G. F. (1995). “CORE-LOC: Optimized concrete armor units," Bulletin No. 87, Permanent International Association of Navigation Congresses, pp 5-21.

Shore protection manual. (1984). 4th ed., 2 Vol, U.S. Army Engineer Waterways Experiment Station, U.S. Government Printing Office, Washington, DC.

Smith, E. R. "Three-dimensional stability tests," in: "Wave response of Kaumalapau Harbor, Lanai, Hawaii," in publication, U.S. Army Engineer Waterways Experiment Station, Vicksburg MS.

Smith, E. R. and Hennington, L. L. (1995). "Noyo Harbor, California, breakwater stability and transmission tests," Technical Report CERC-95-17, U.S. Army Engineer Waterways Experiment Station, Vicksburg, MS.

Stevens, J. C., Bardsley, C. E., Lane, E. W., and Straub, L. G. (1942). "Hydraulic Models," in Manuals on Engineering Practice No. 25, American Society of Civil Engineers, New York. 



\section{Appendix A Photographs}




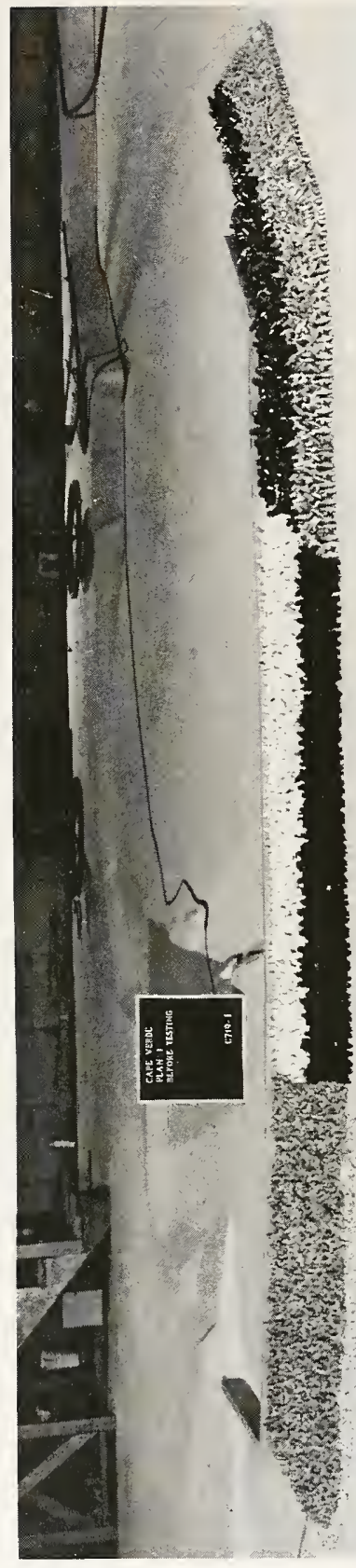

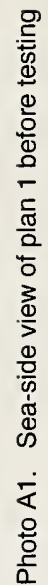




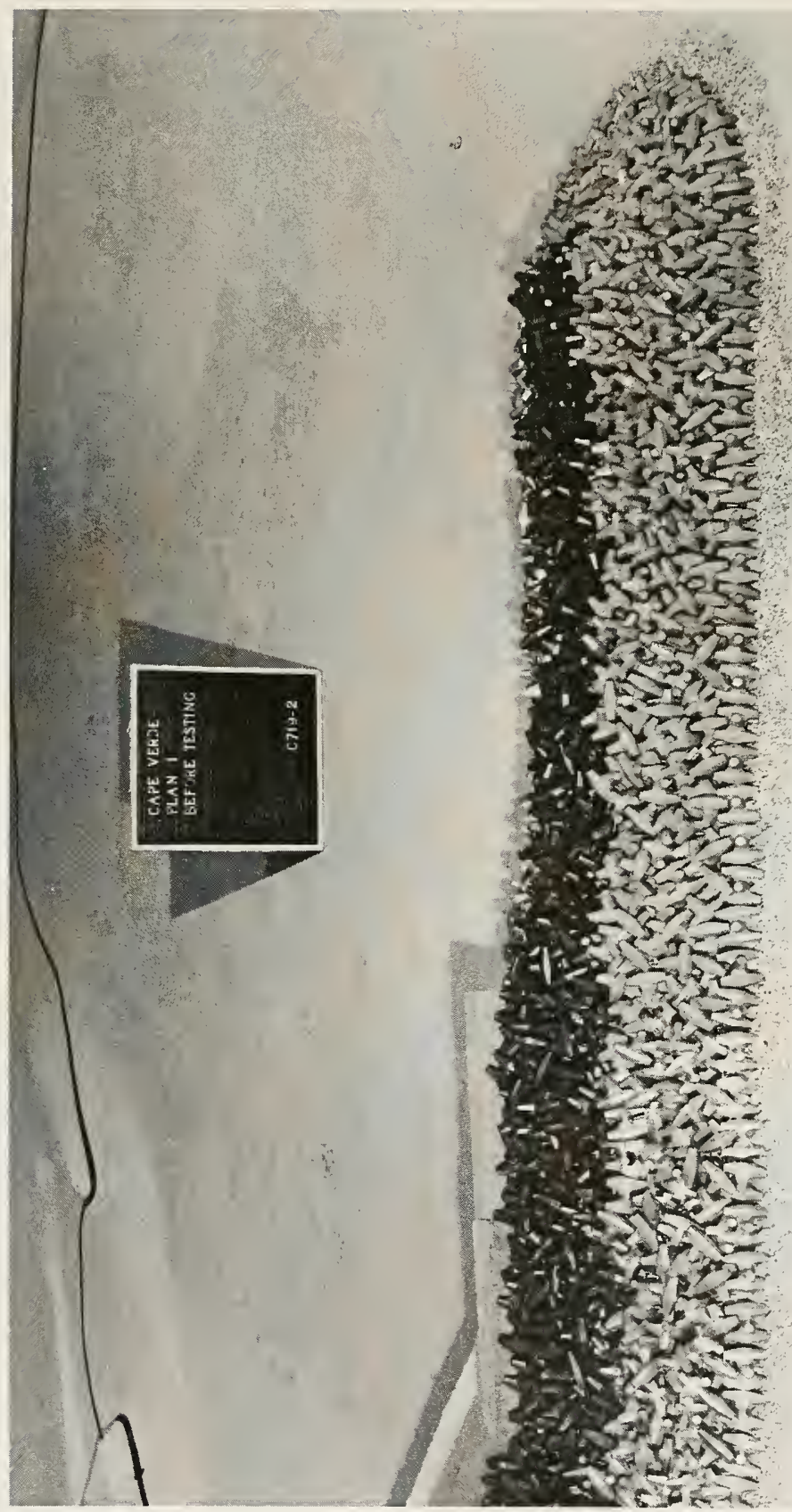

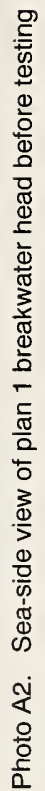




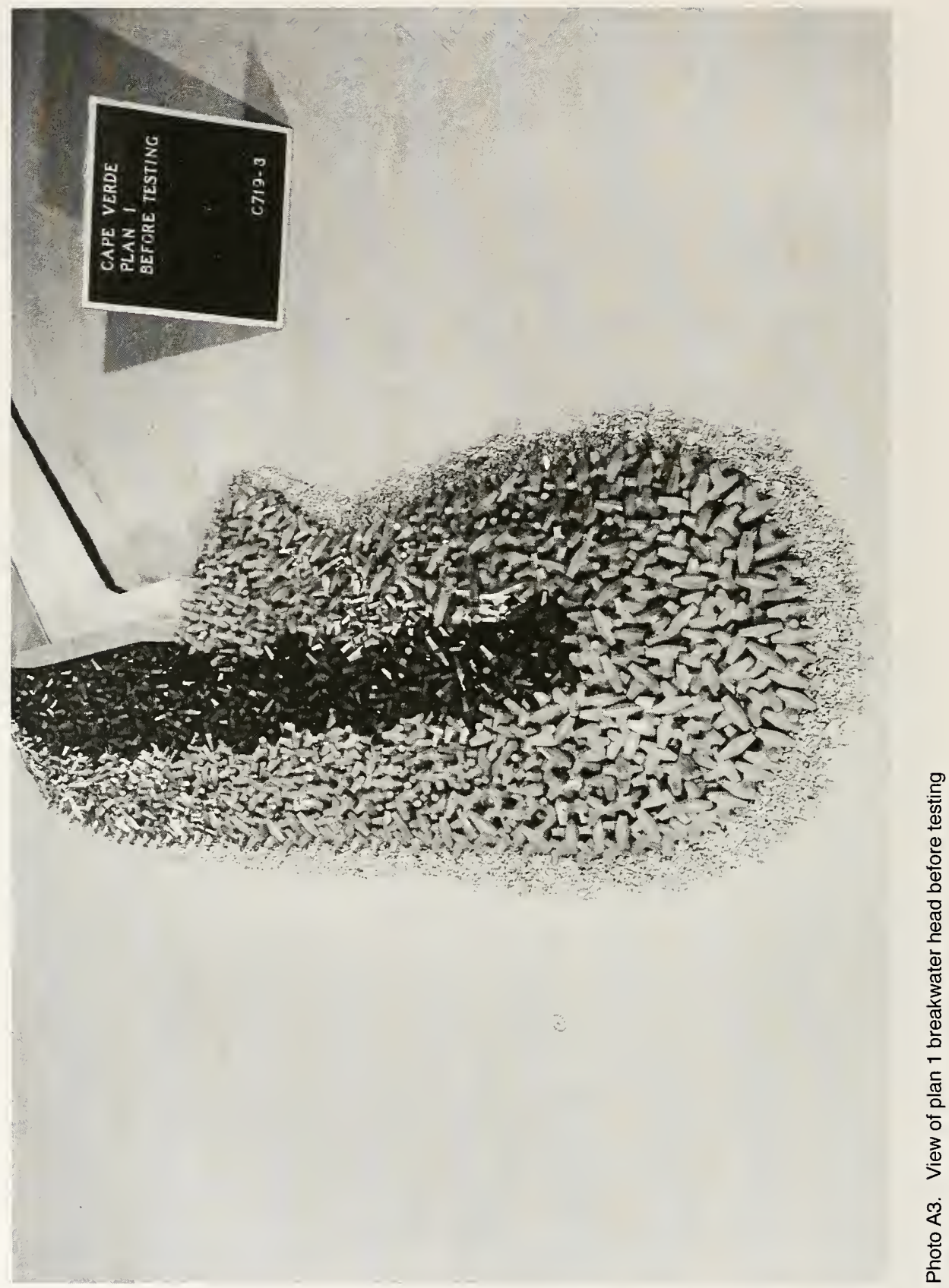




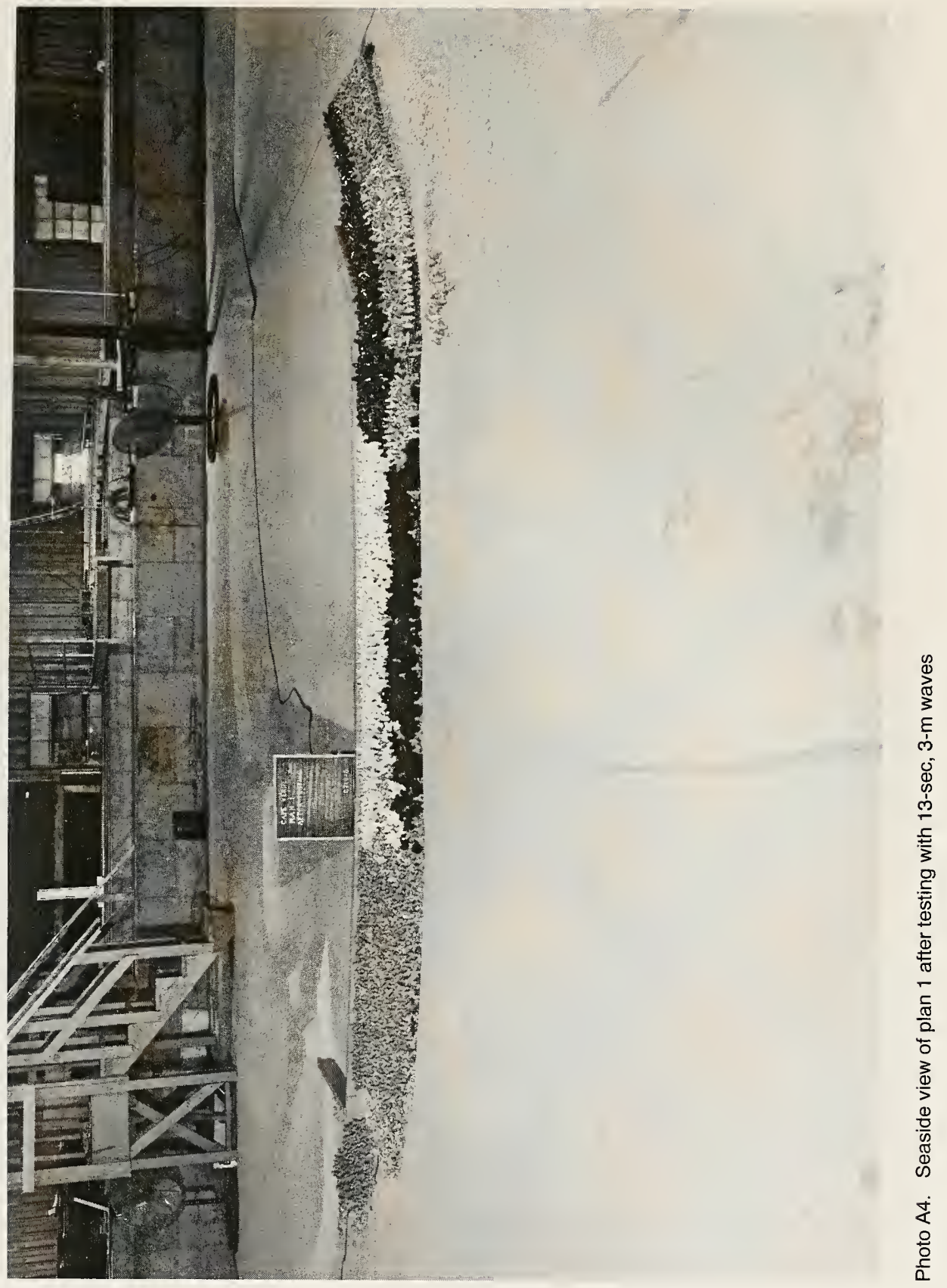




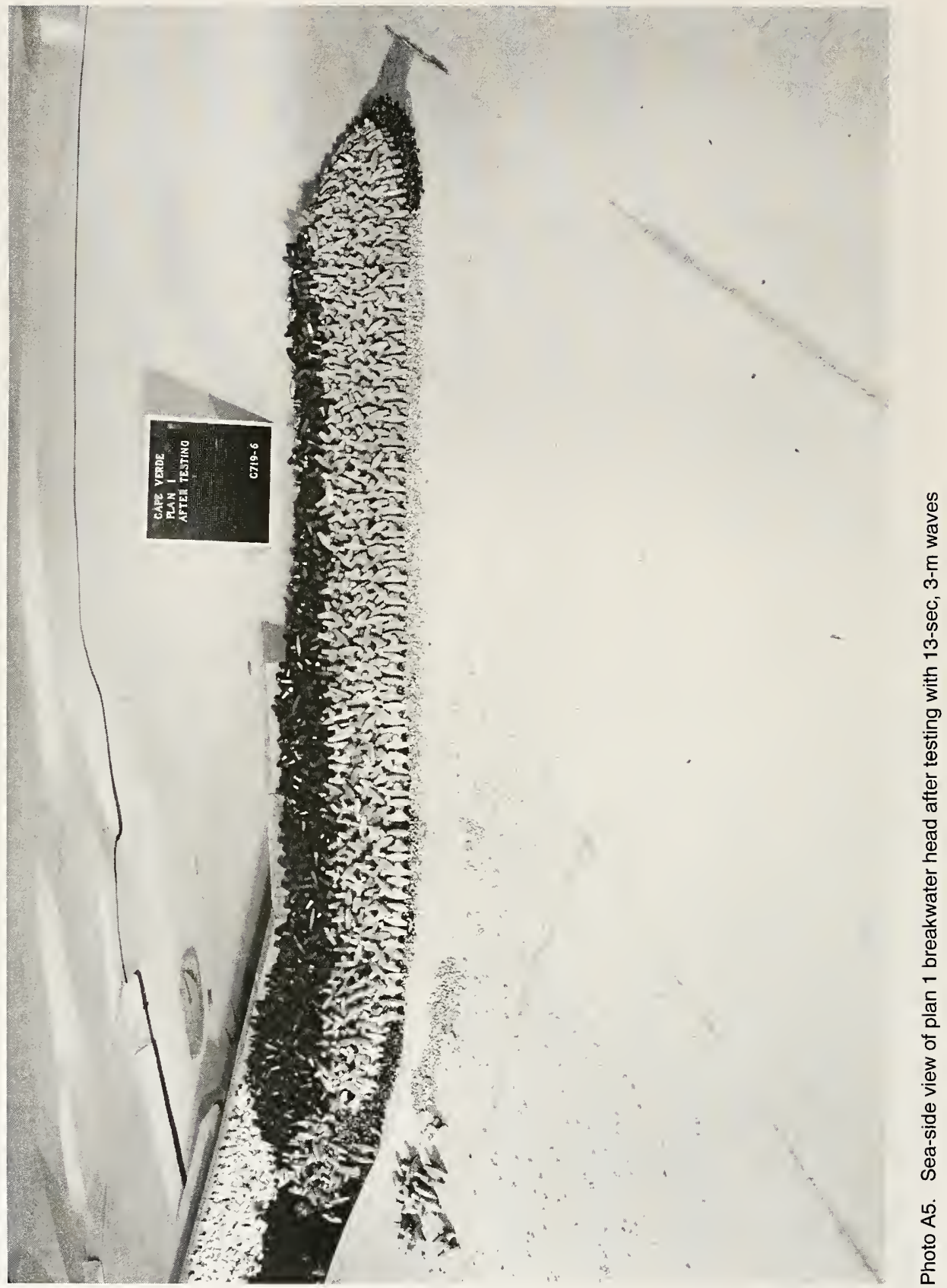




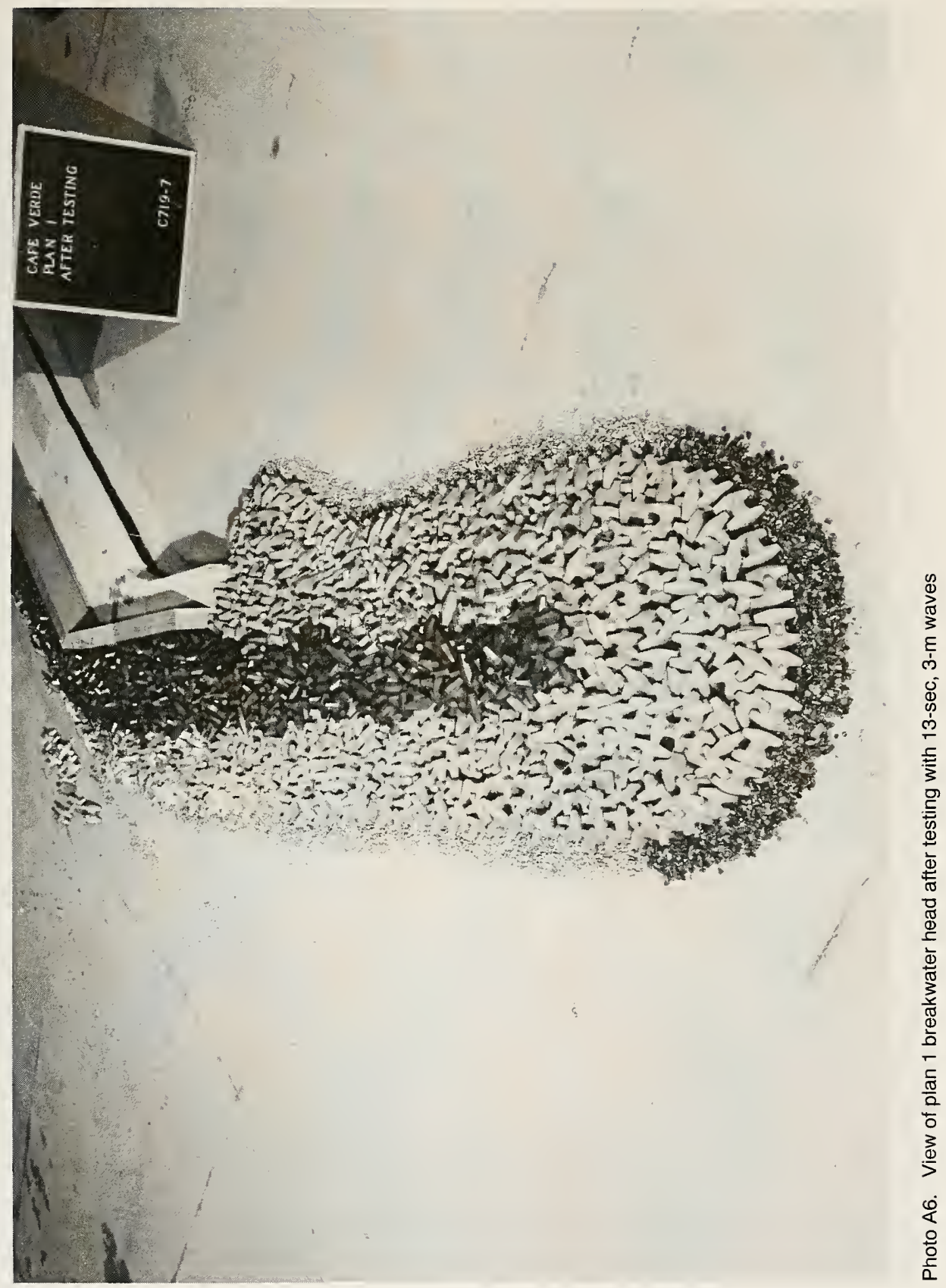




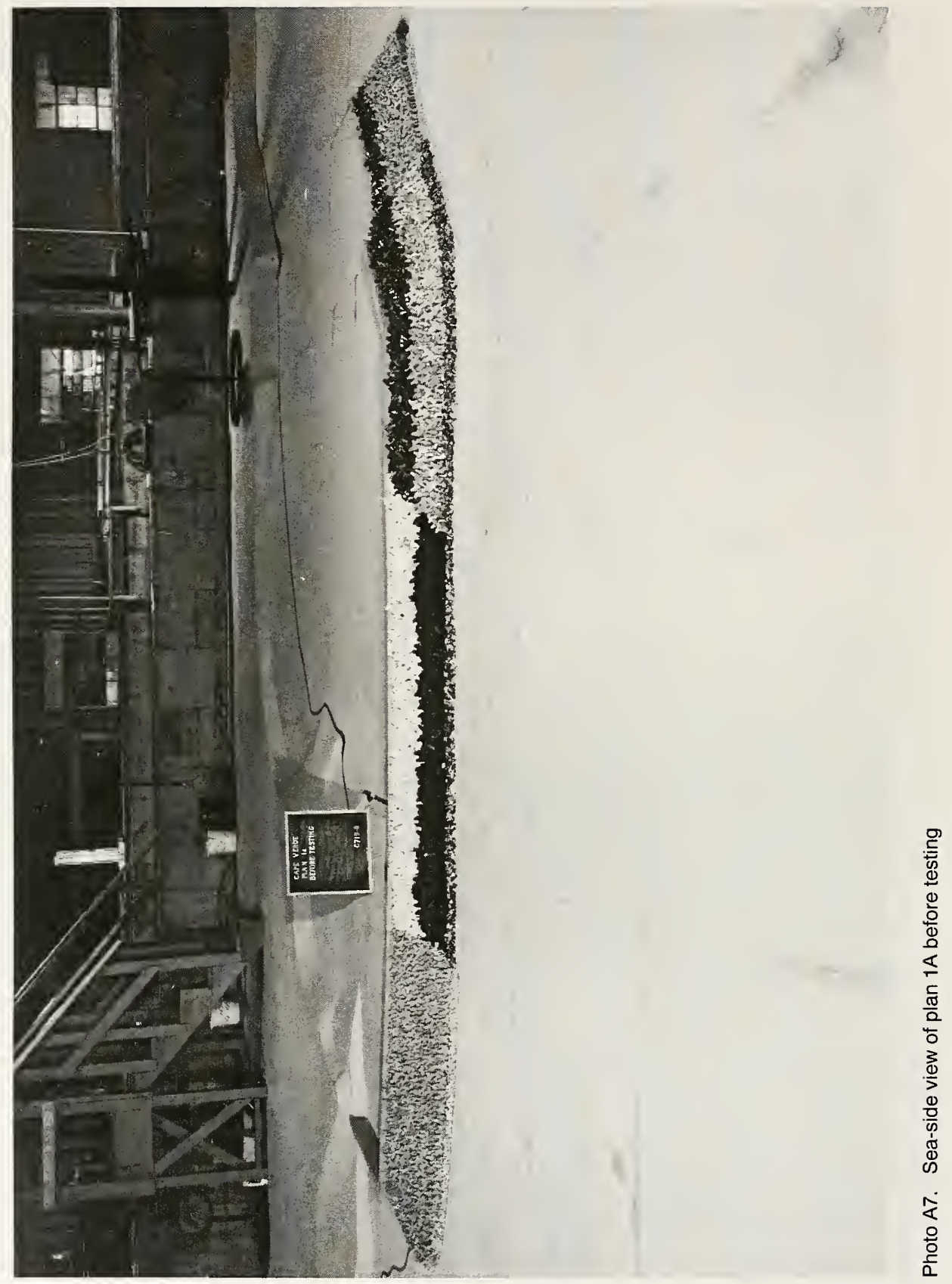




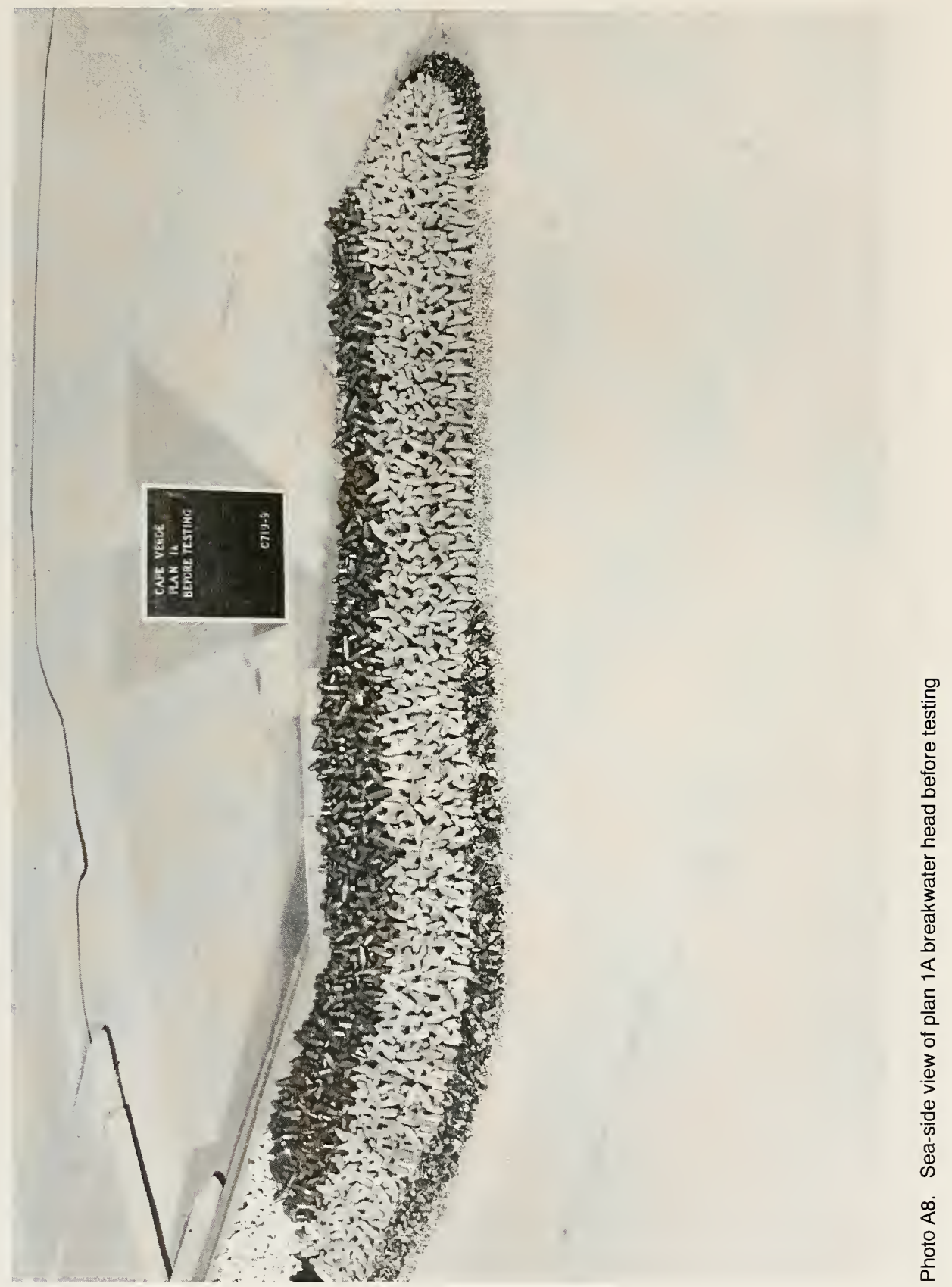




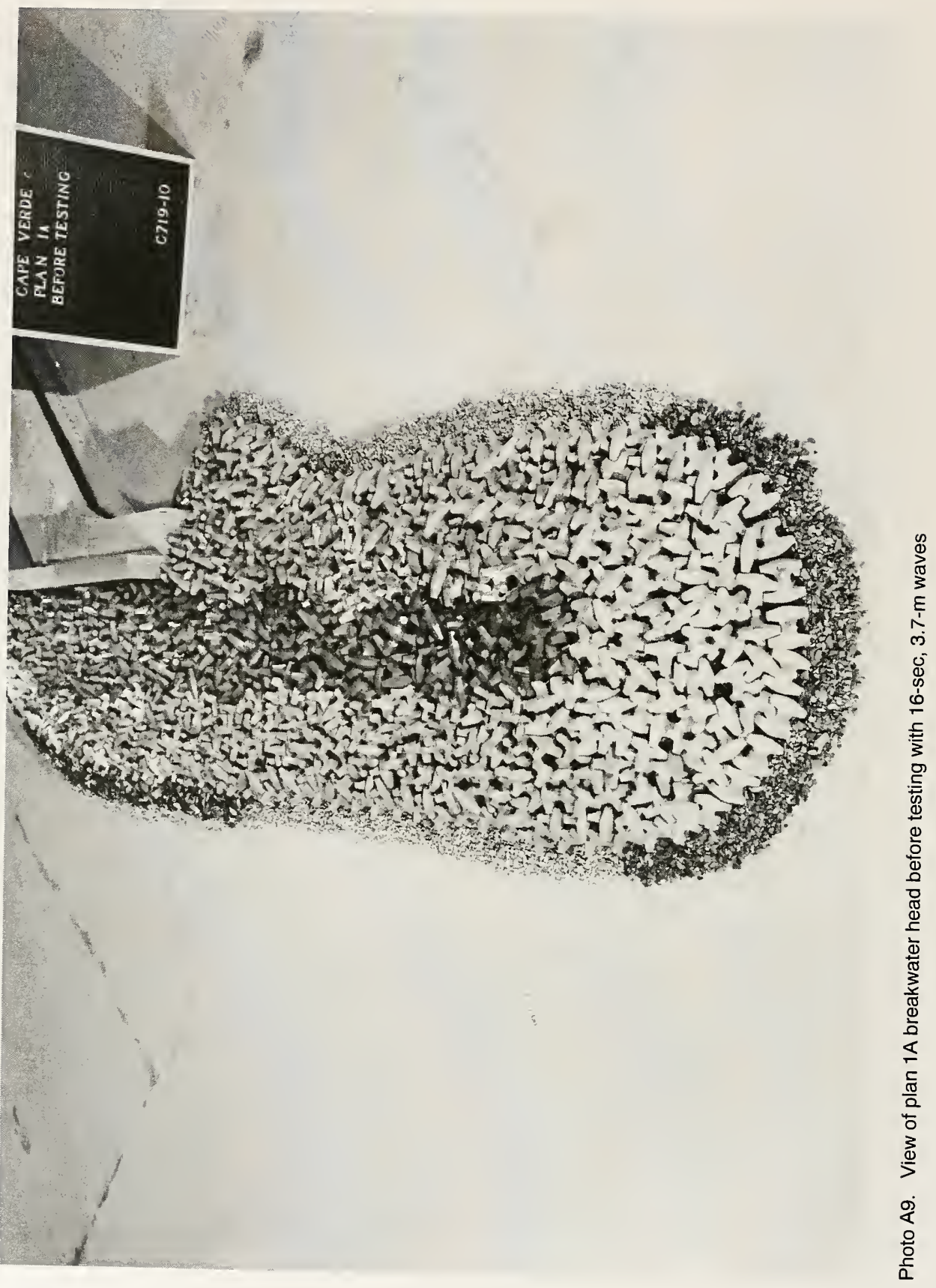




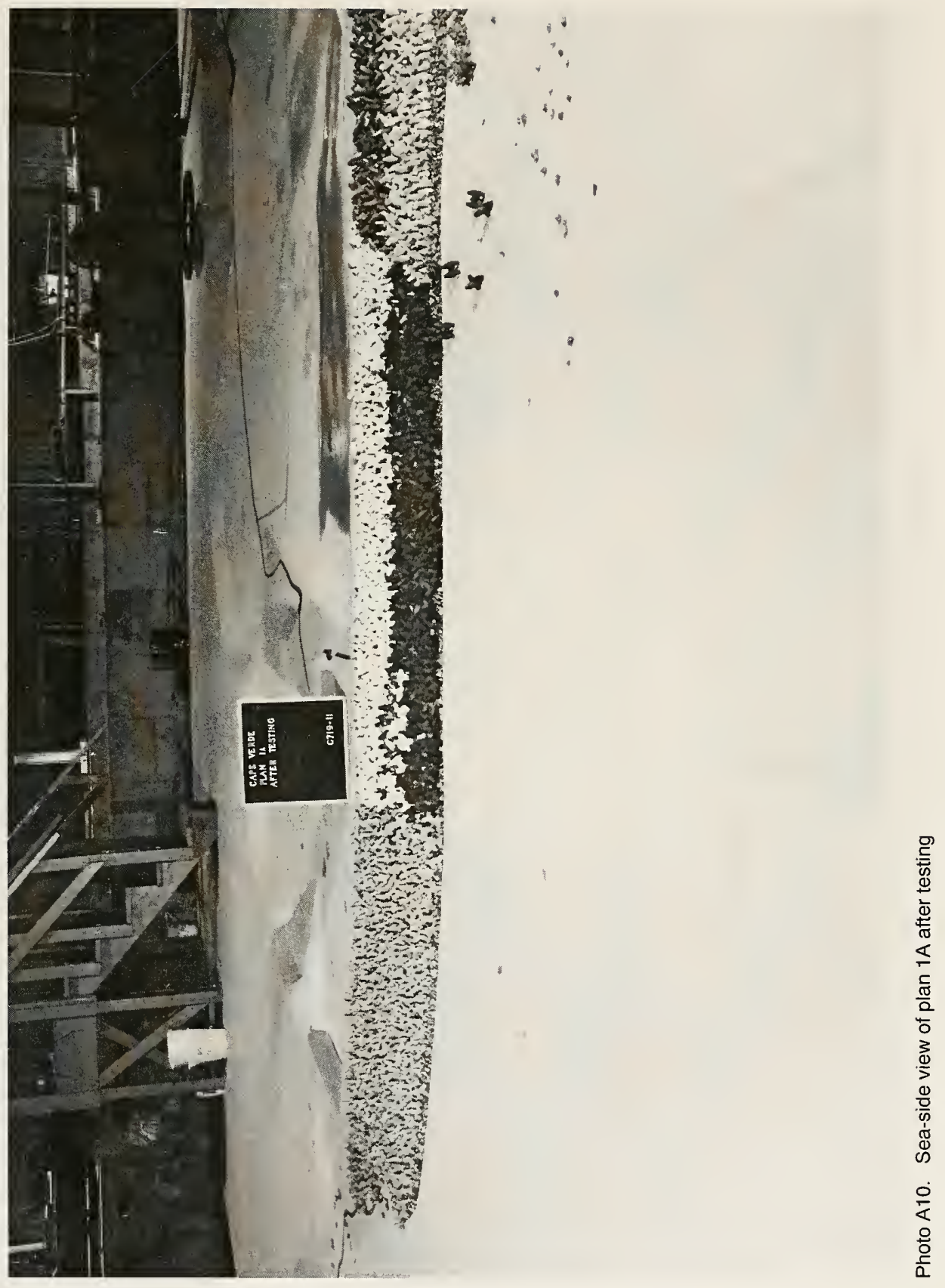




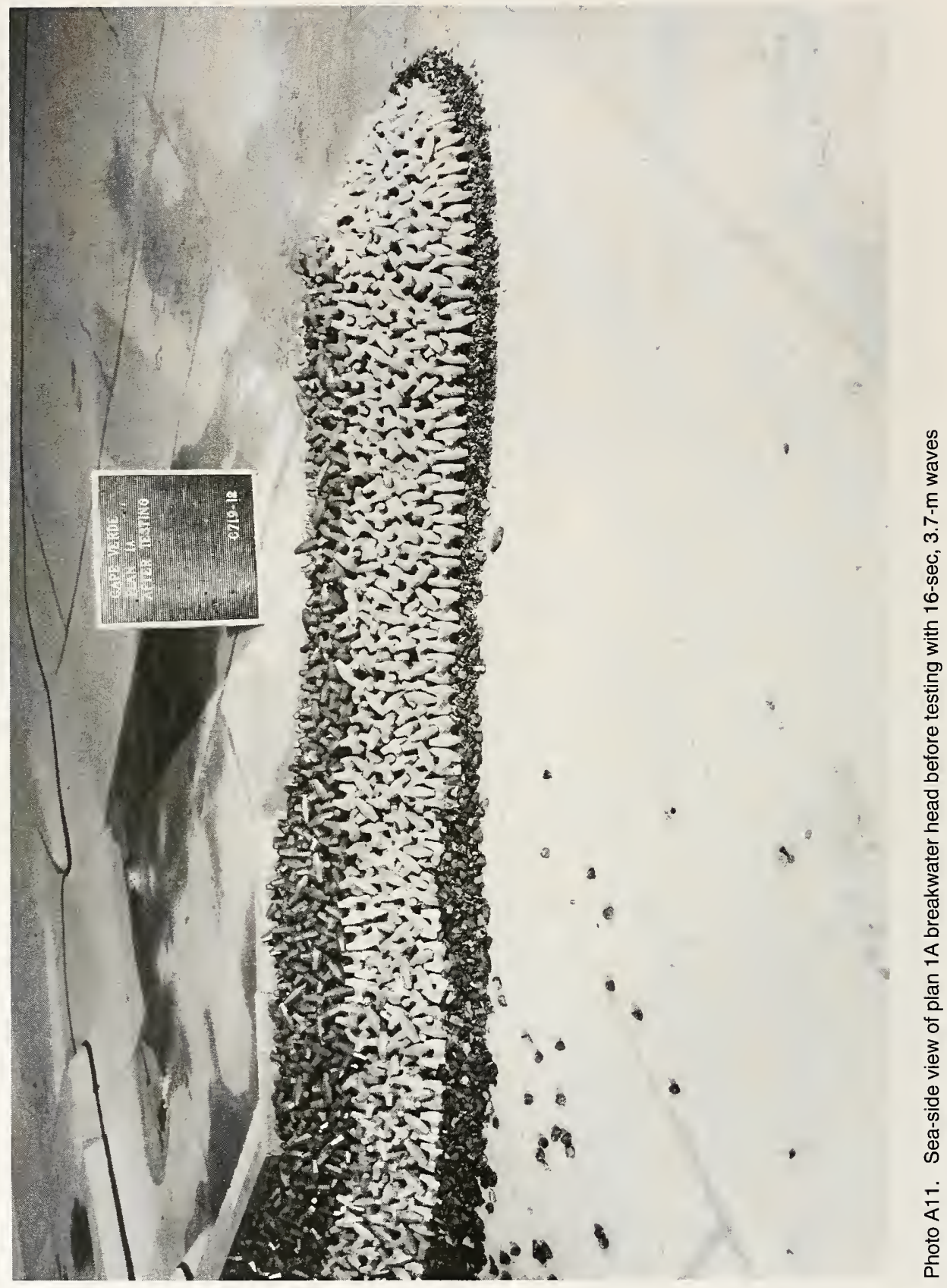




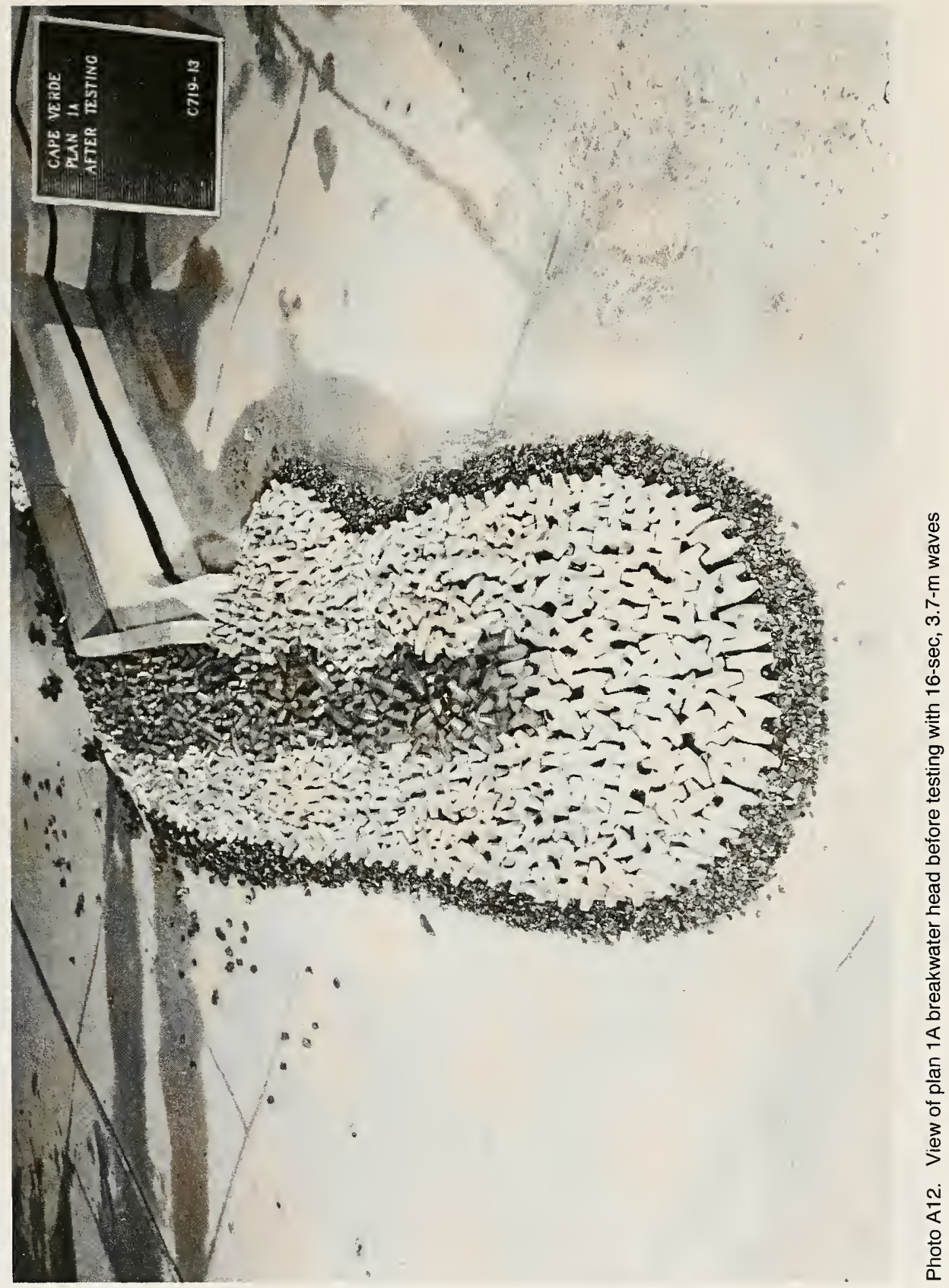



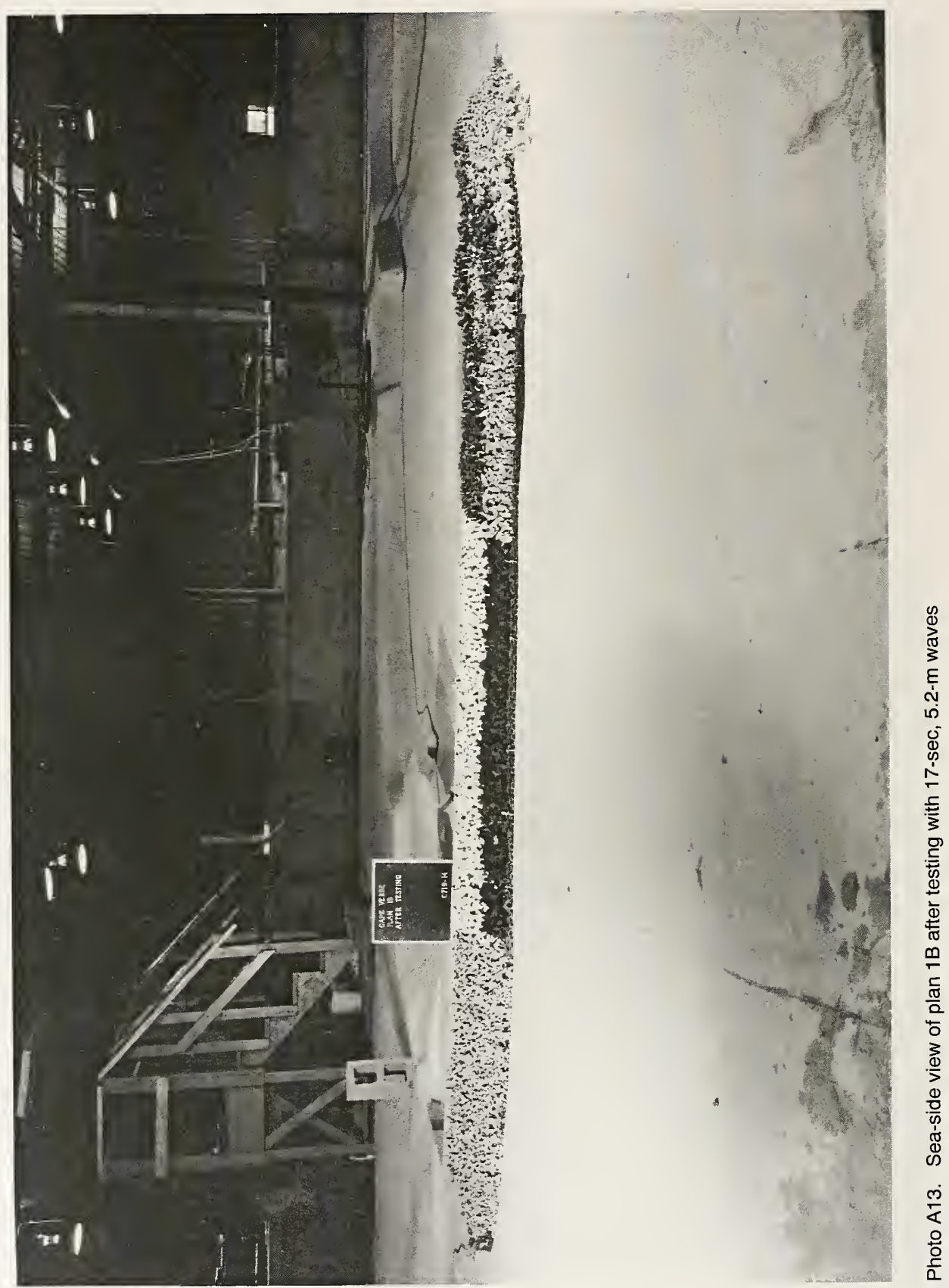


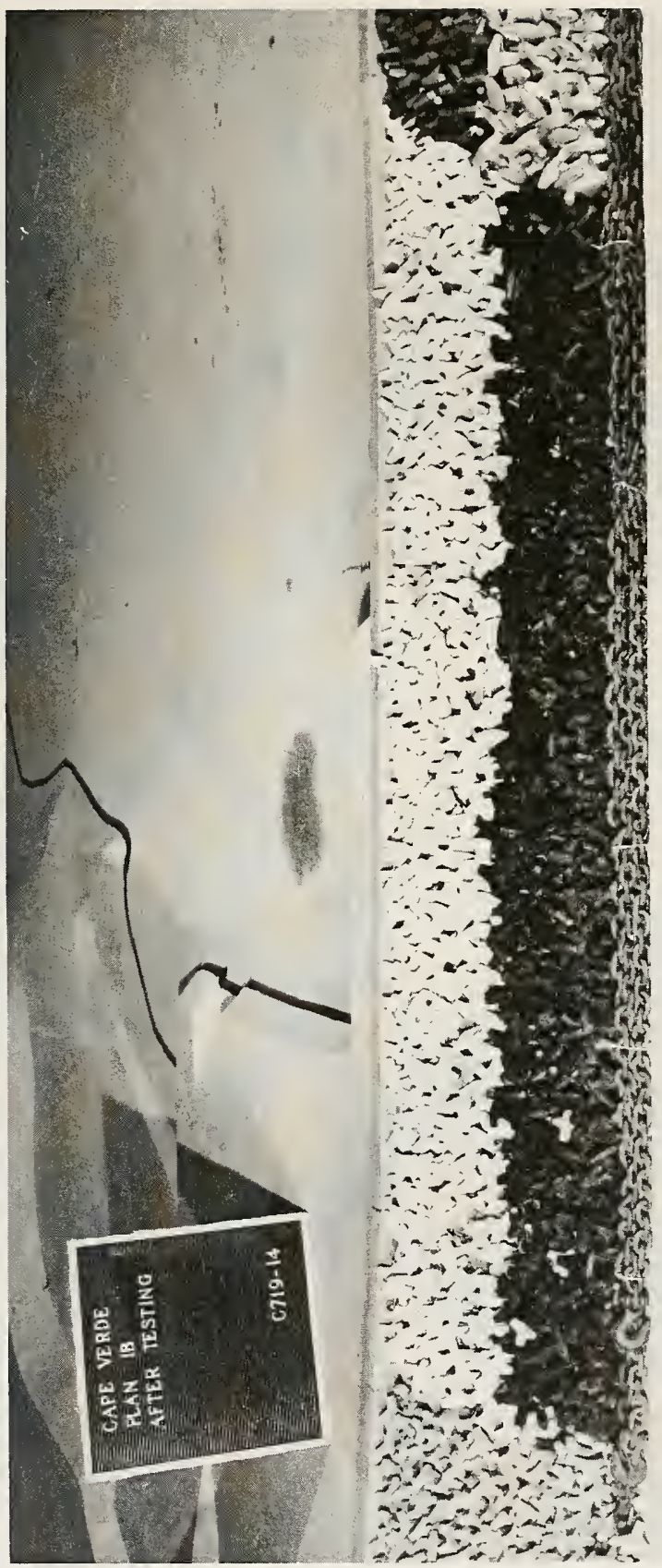

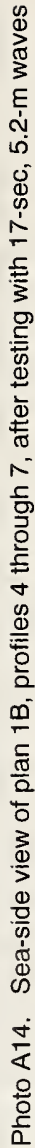




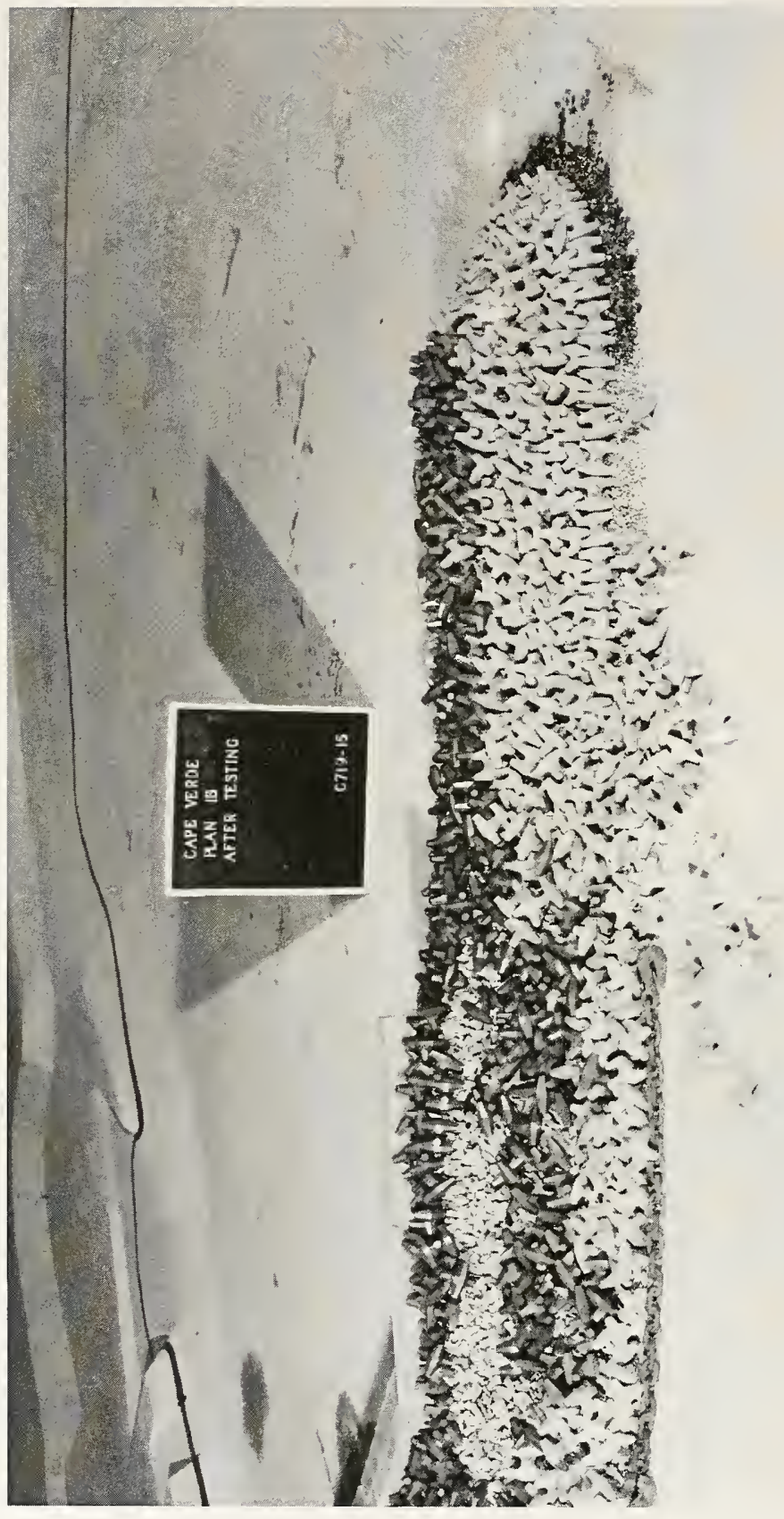

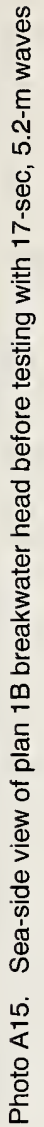




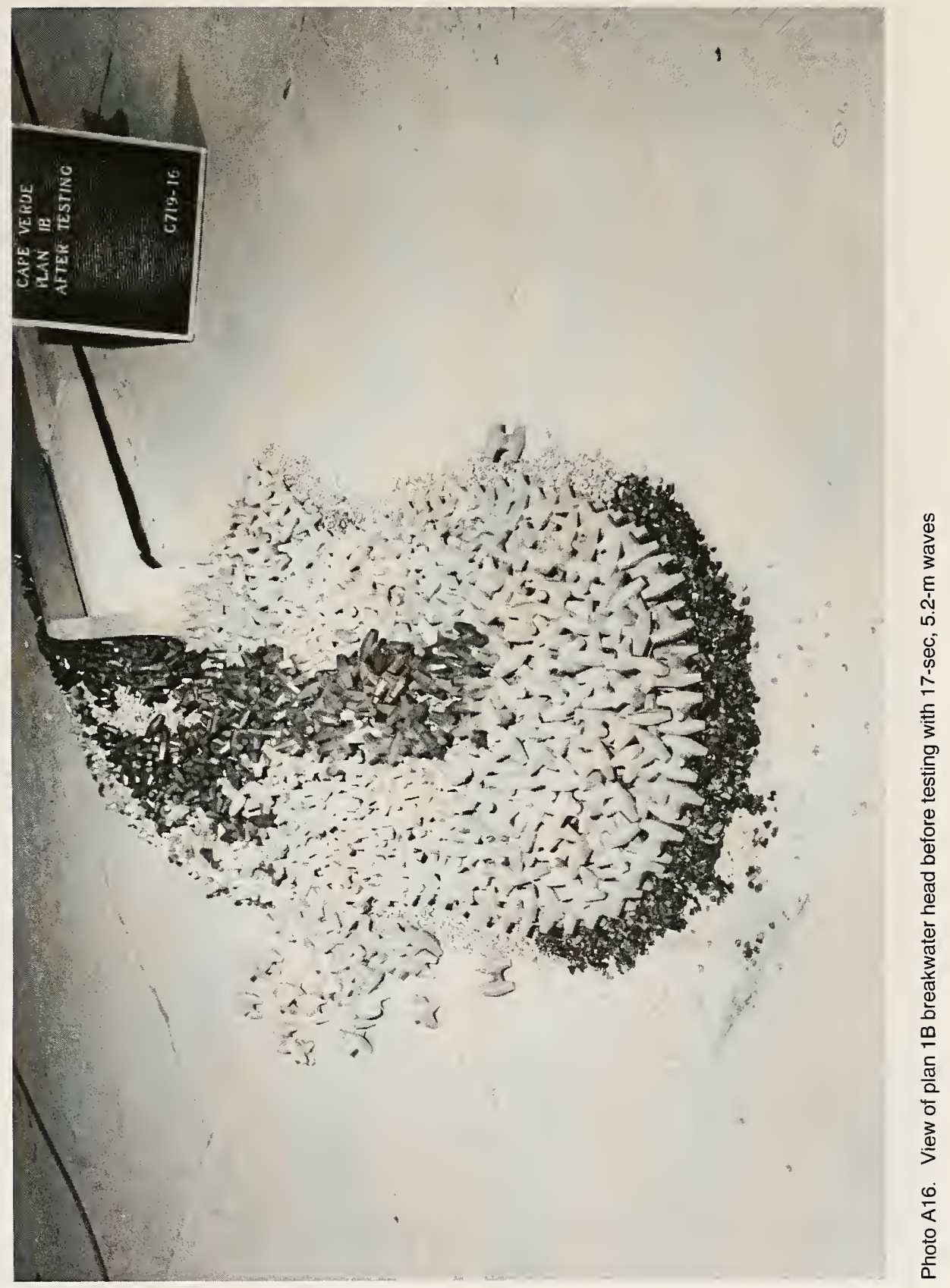




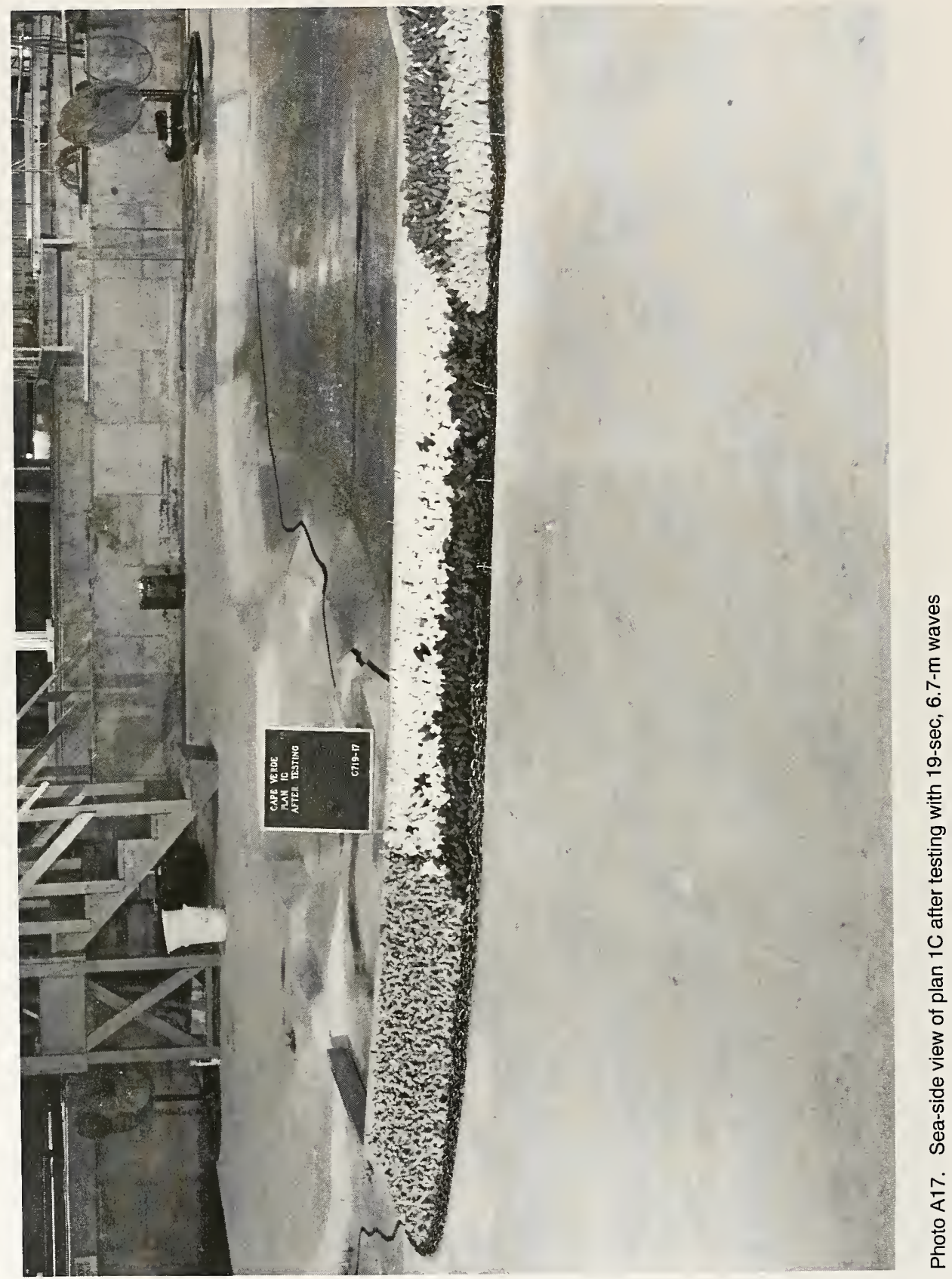




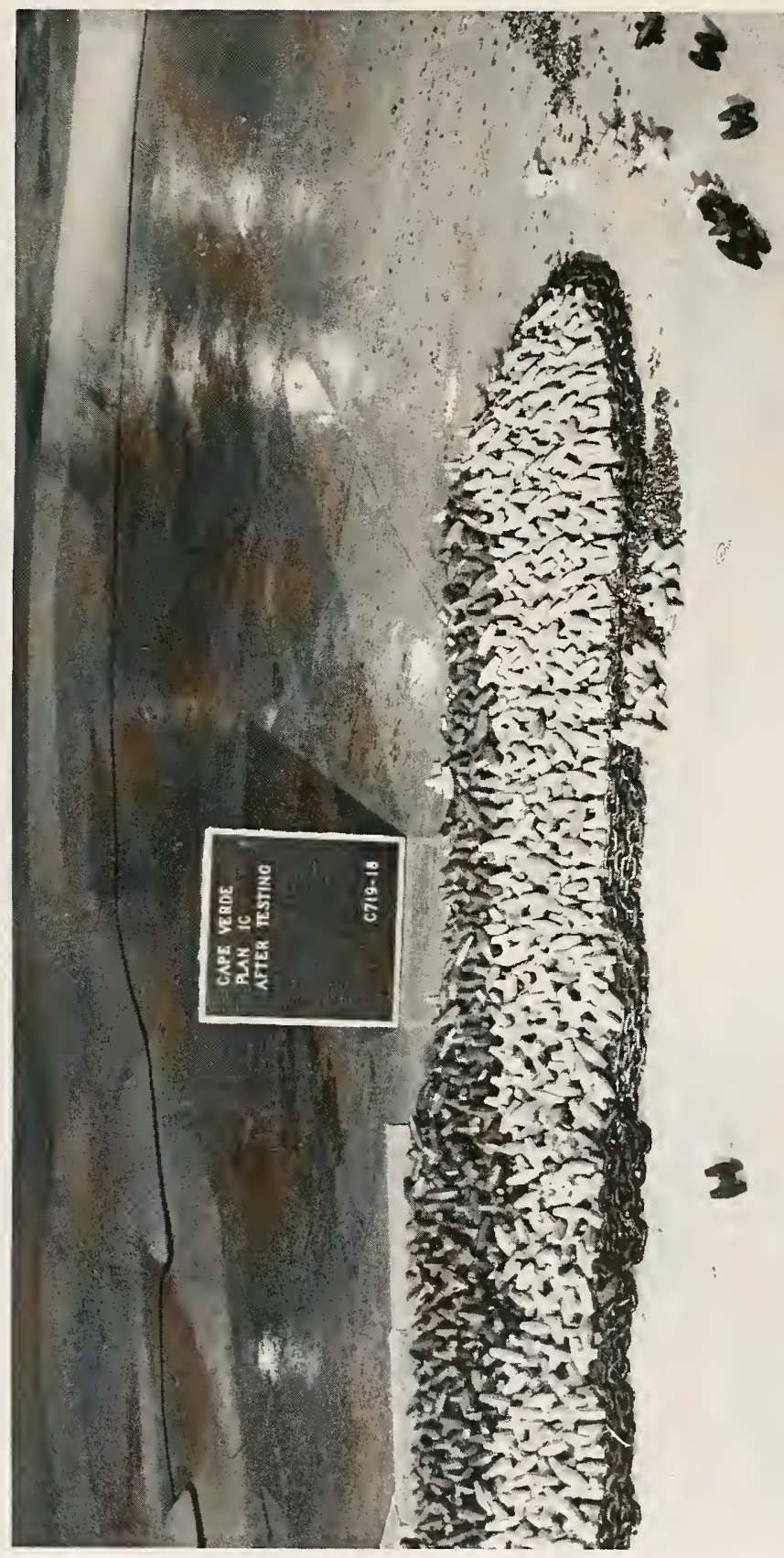

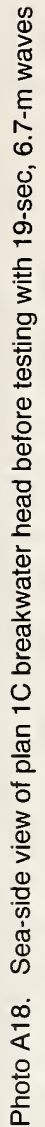




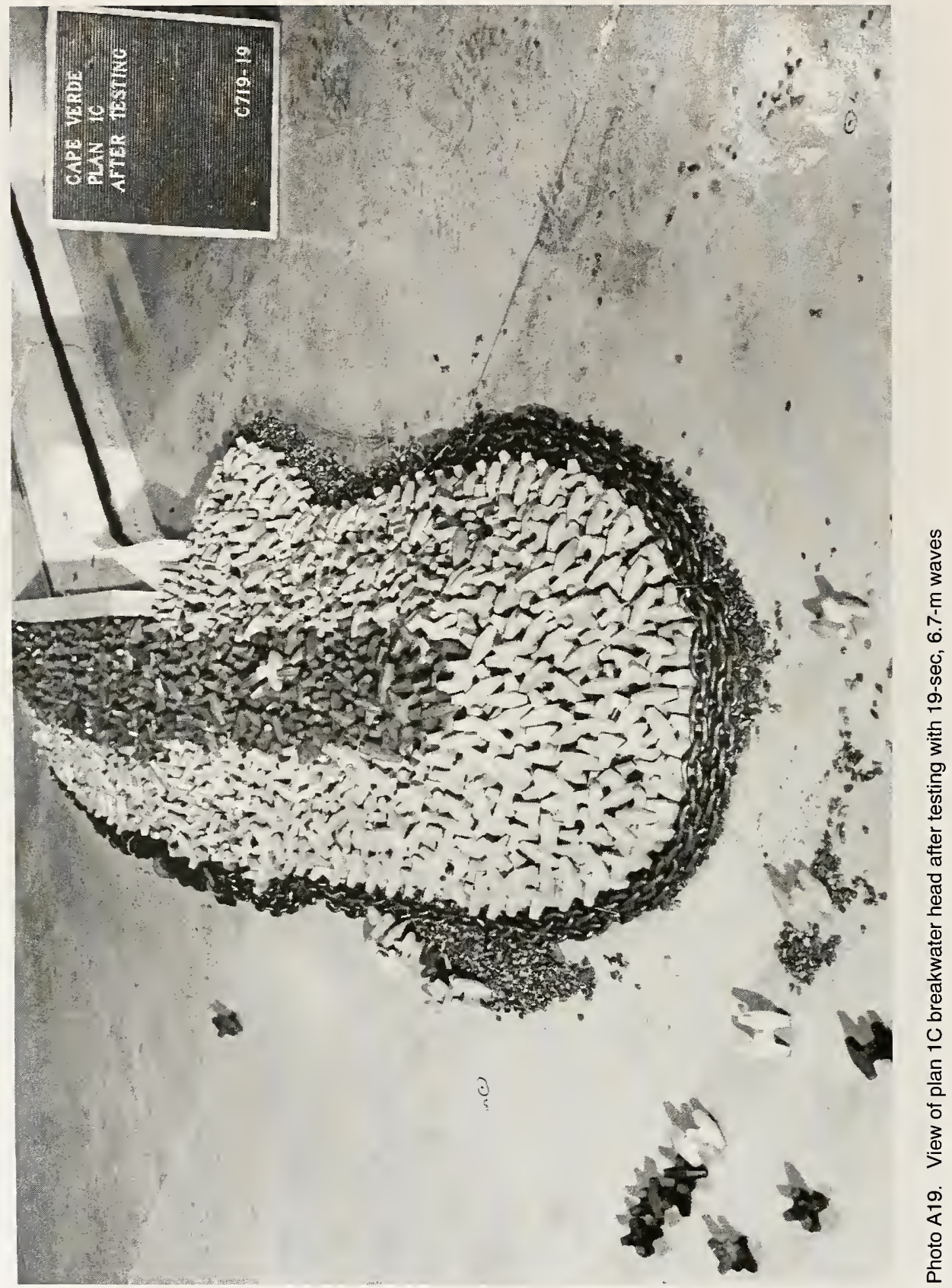




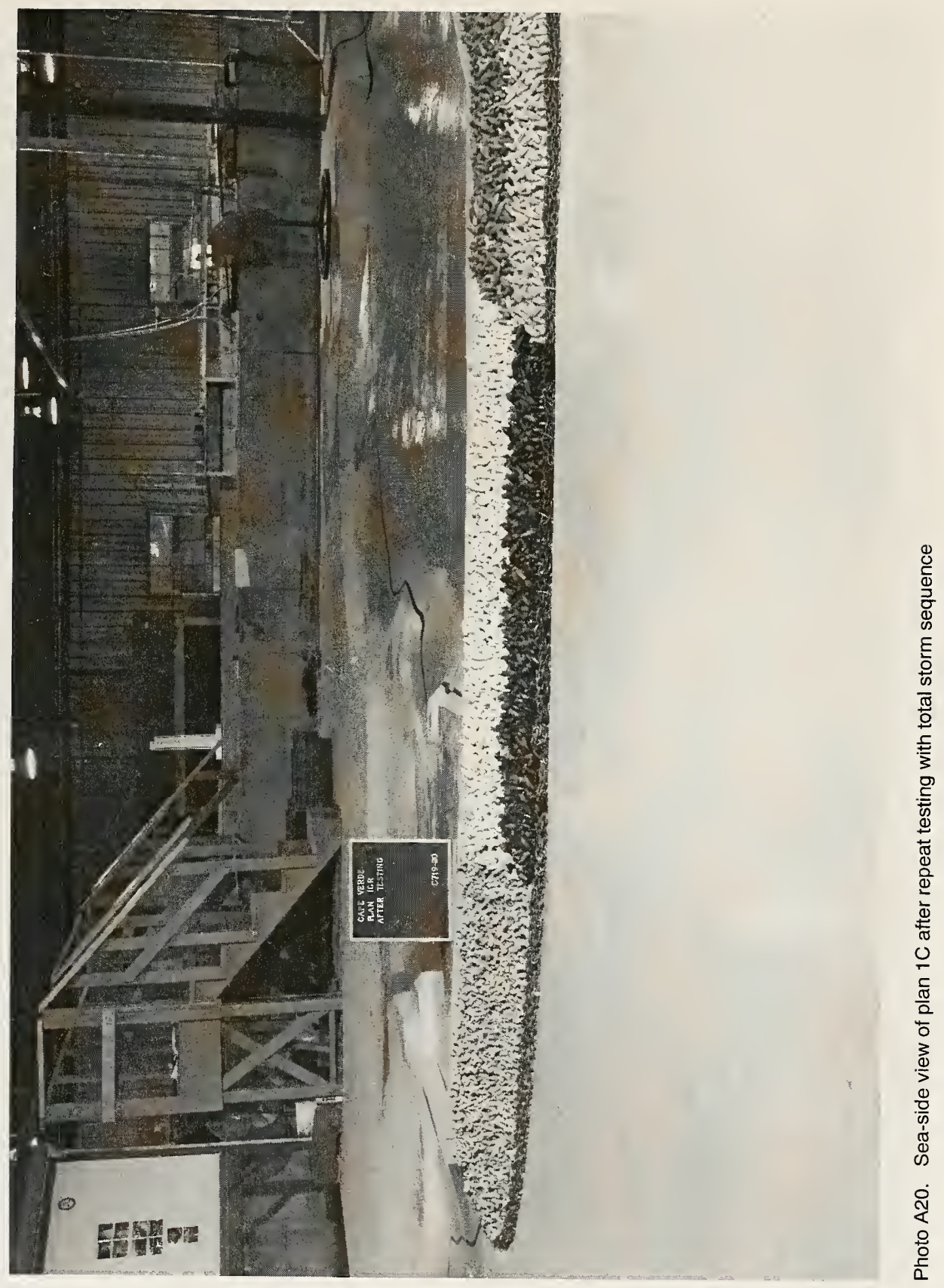




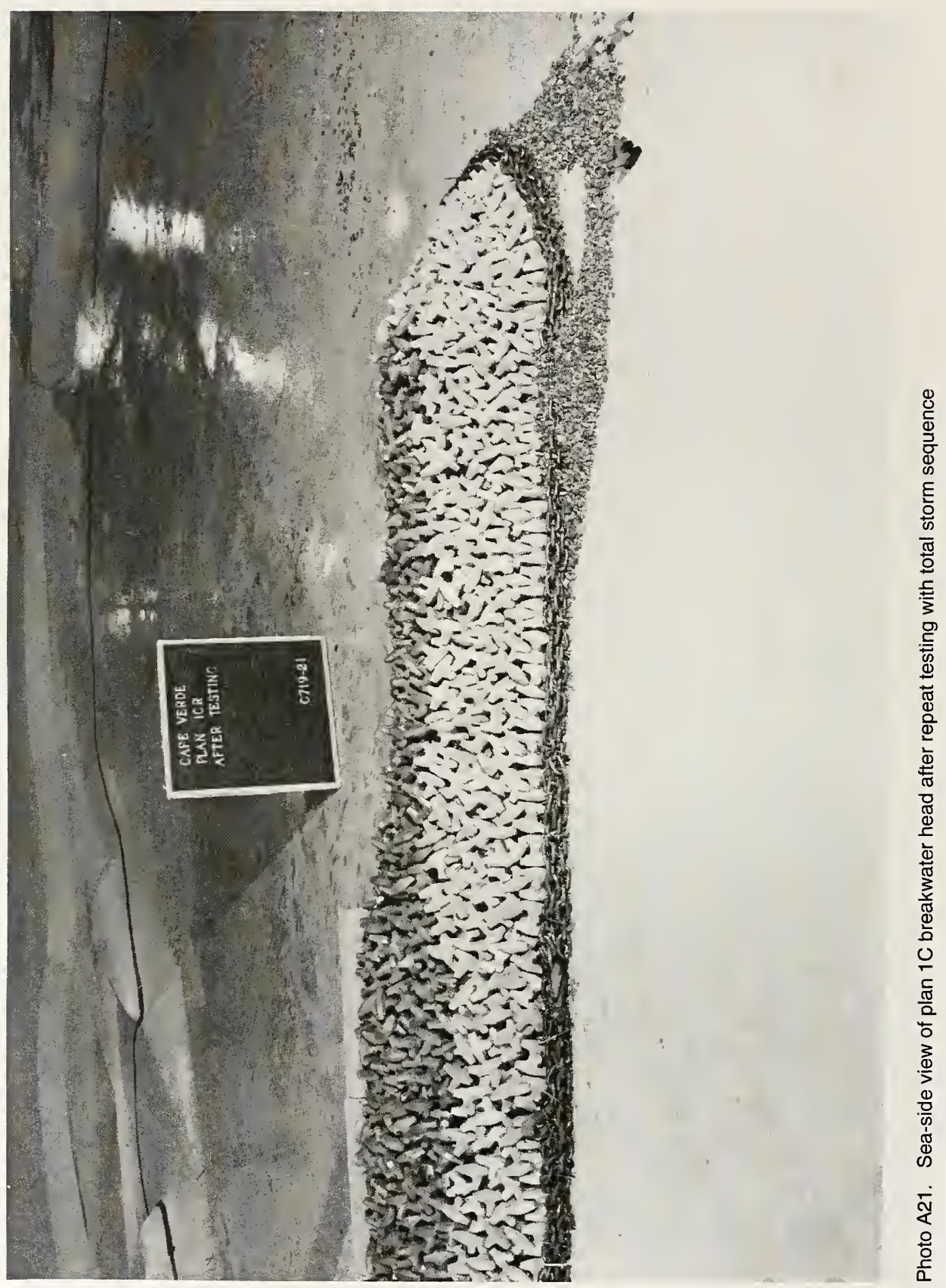




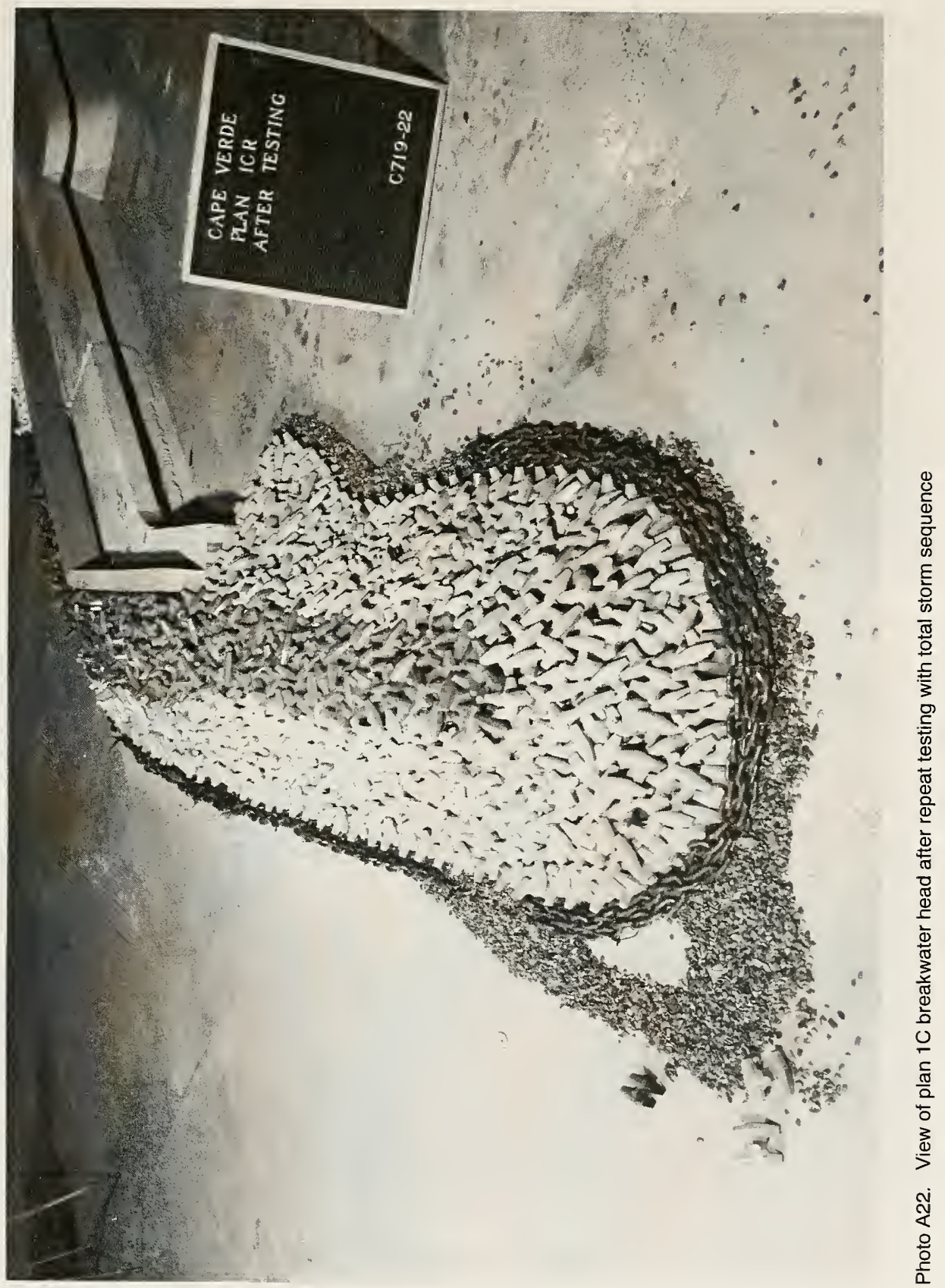




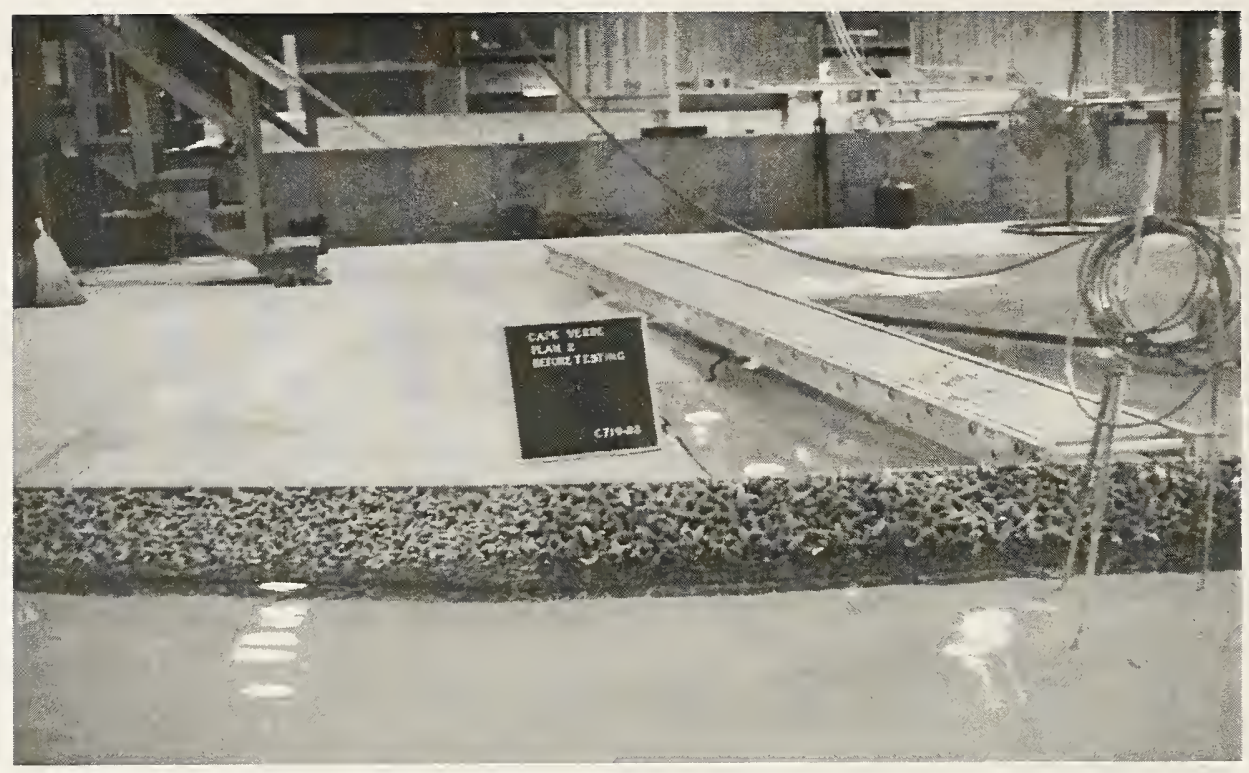

Photo A23. Sea-side view of plan 2 breakwater trunk before testing

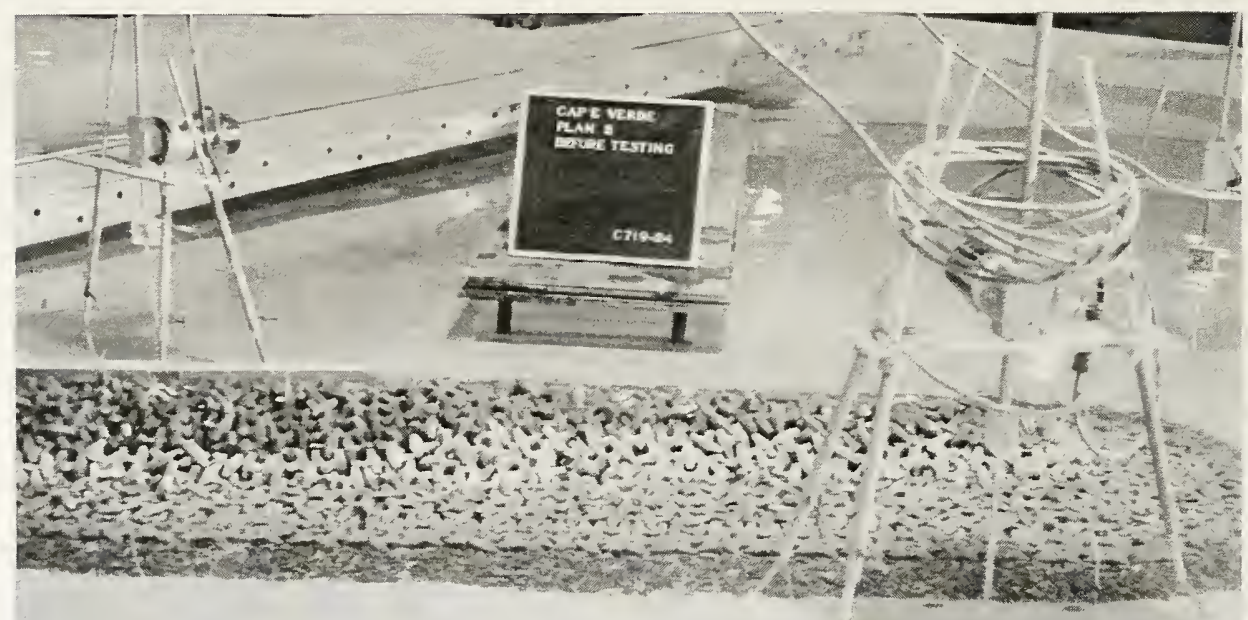

Photo A24. Sea-side view of plan 2 breakwater head before testing 


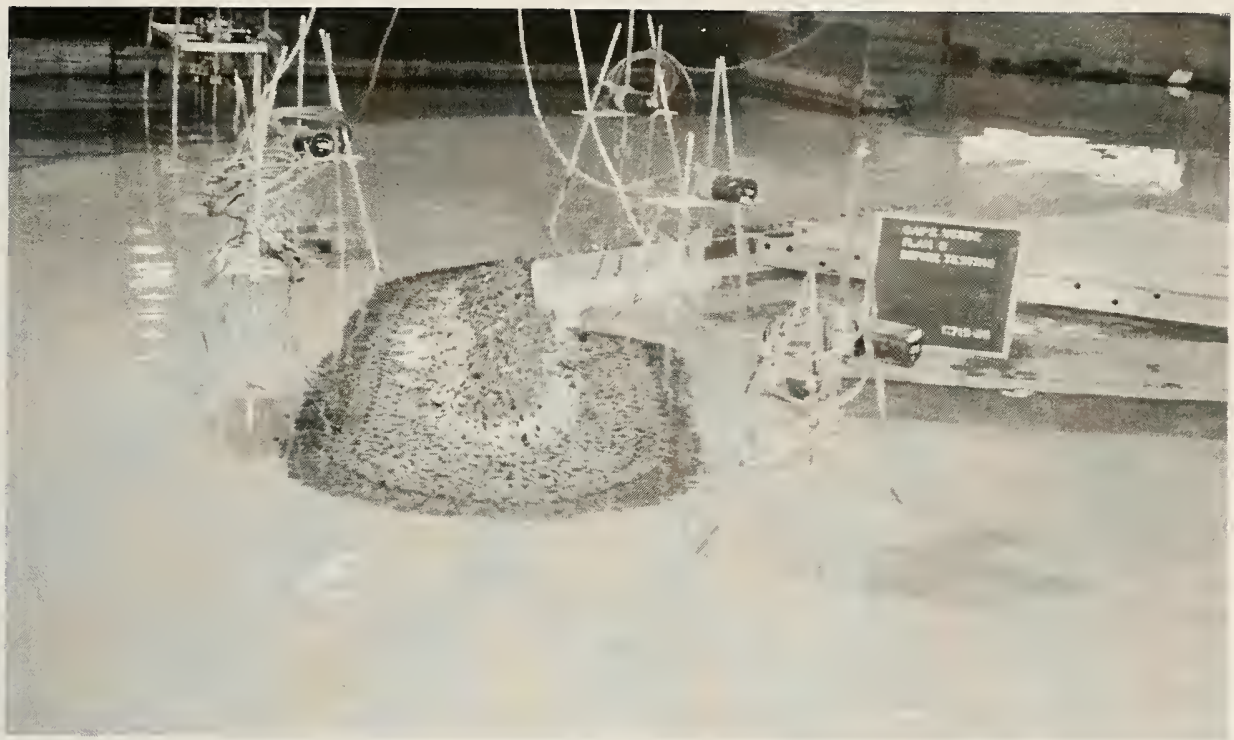

Photo A25. View of plan 2 breakwater head before testing

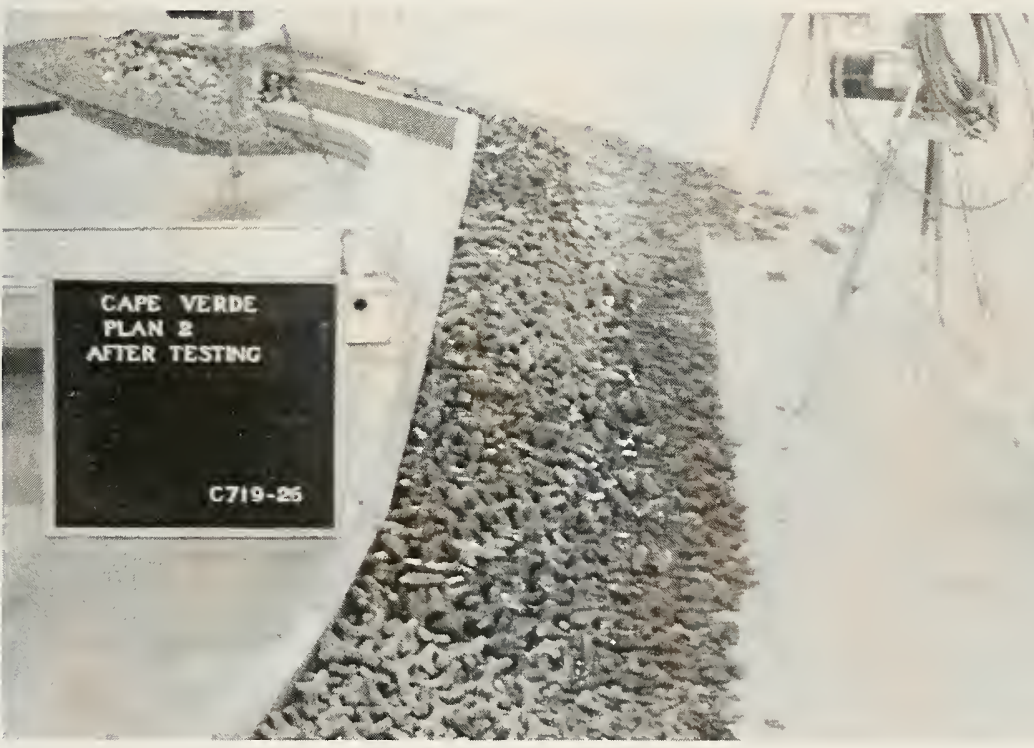

Photo A26. View from north of plan 2 breakwater trunk after testing with 13- and 16-sec, 3.7-m waves 


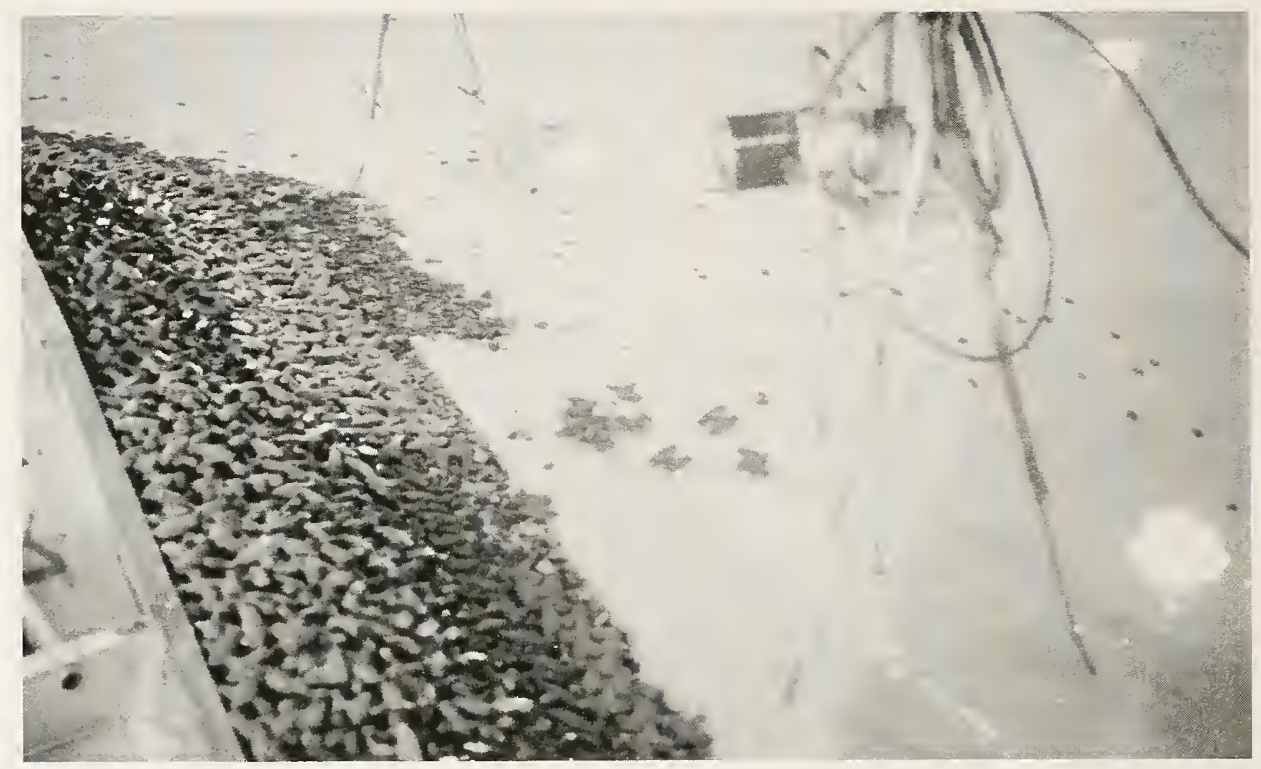

Photo A27. View of plan 2 breakwater trunk, profiles 6 to 8 , after testing with $15-\mathrm{sec}$ and 16 -sec waves 


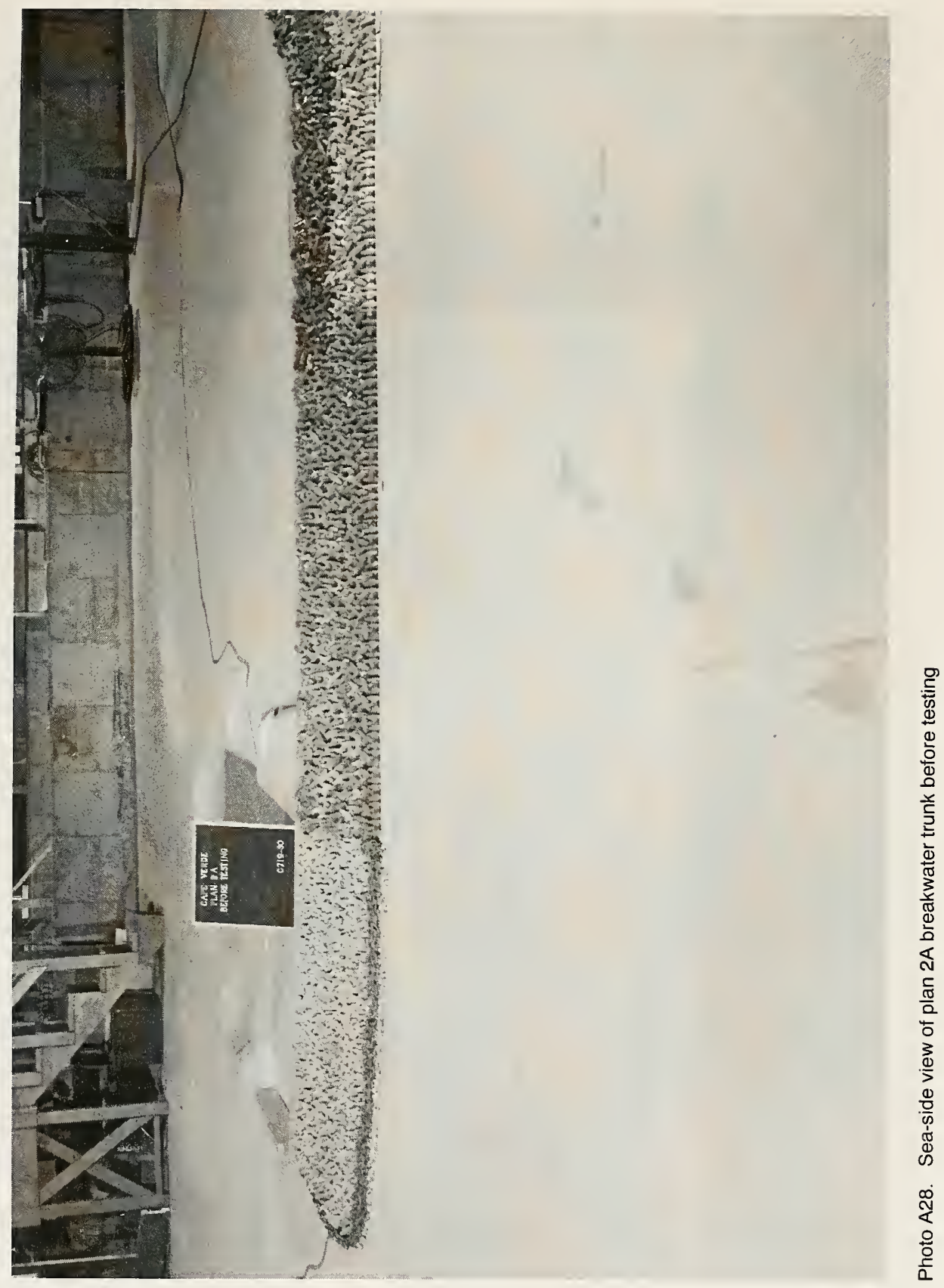




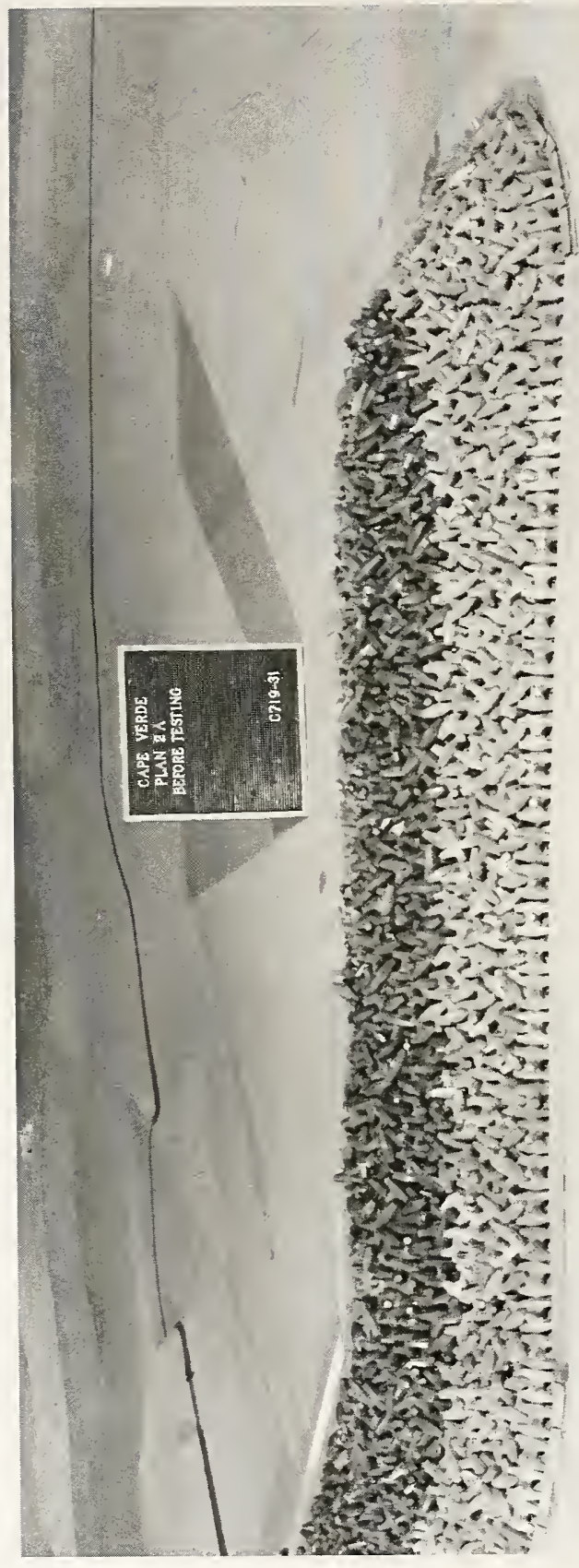

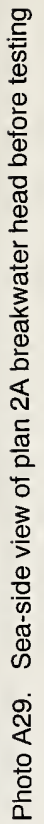




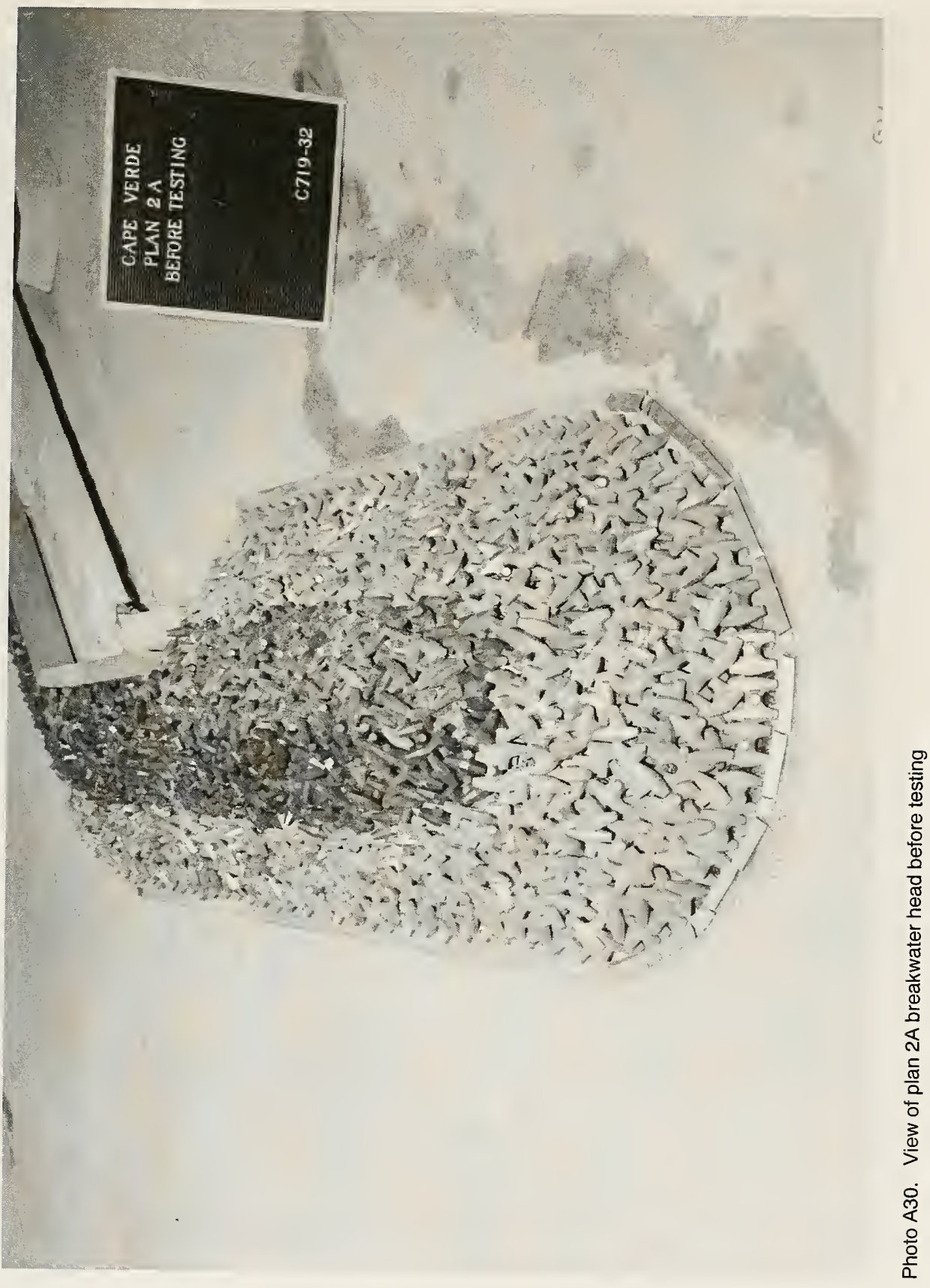




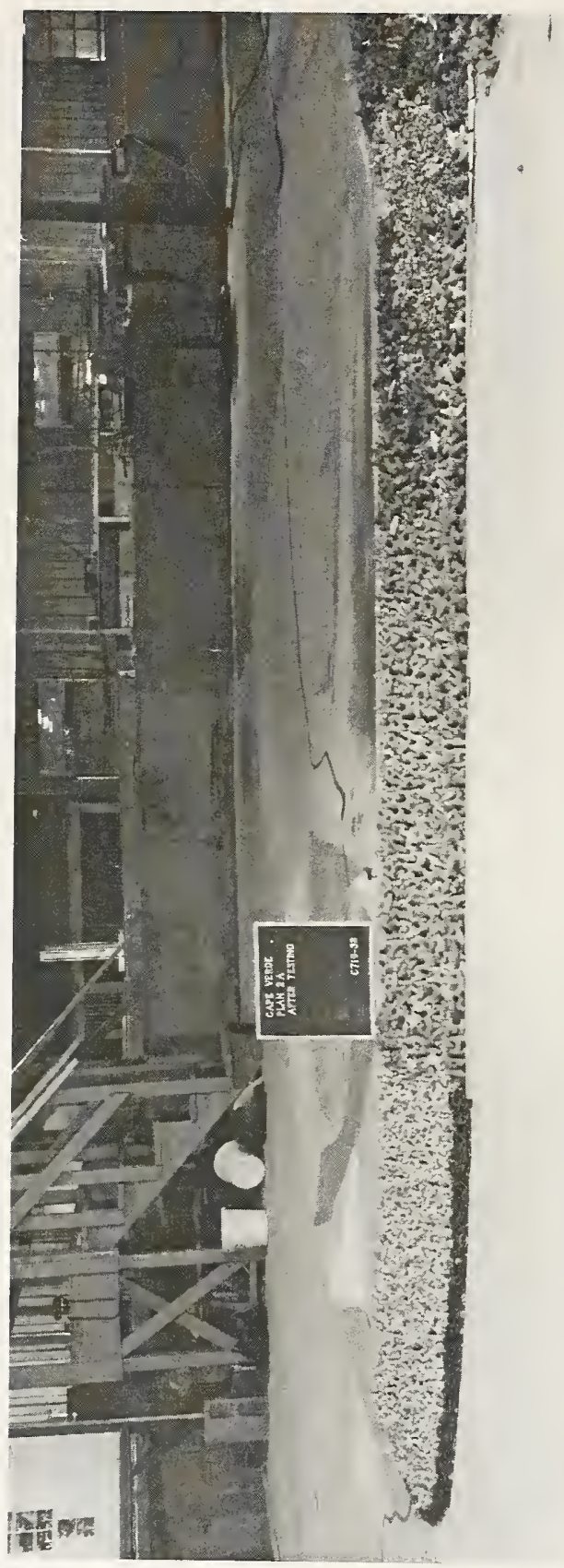

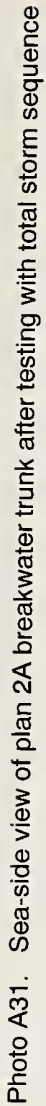




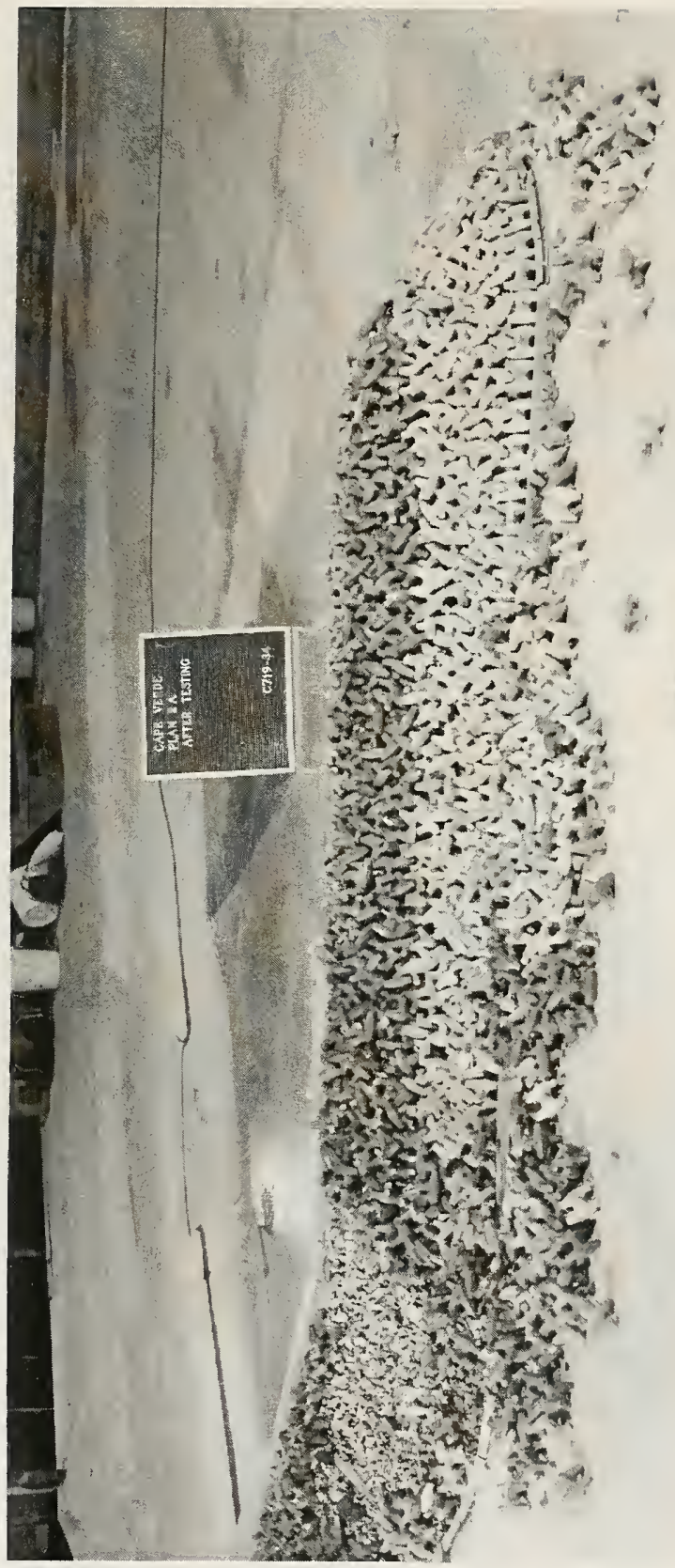

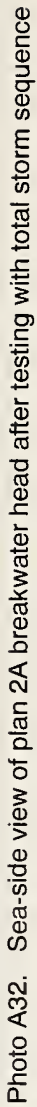




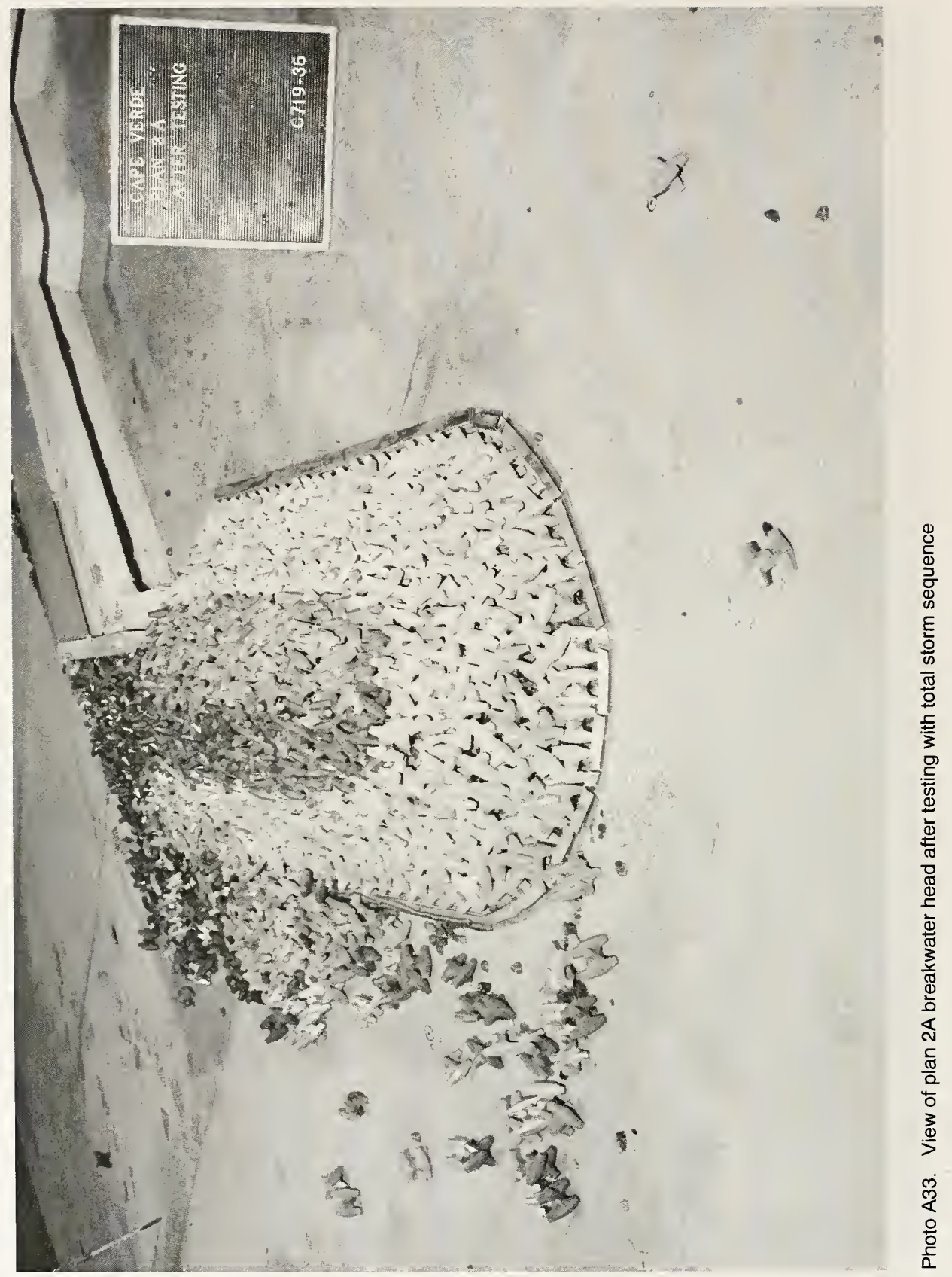




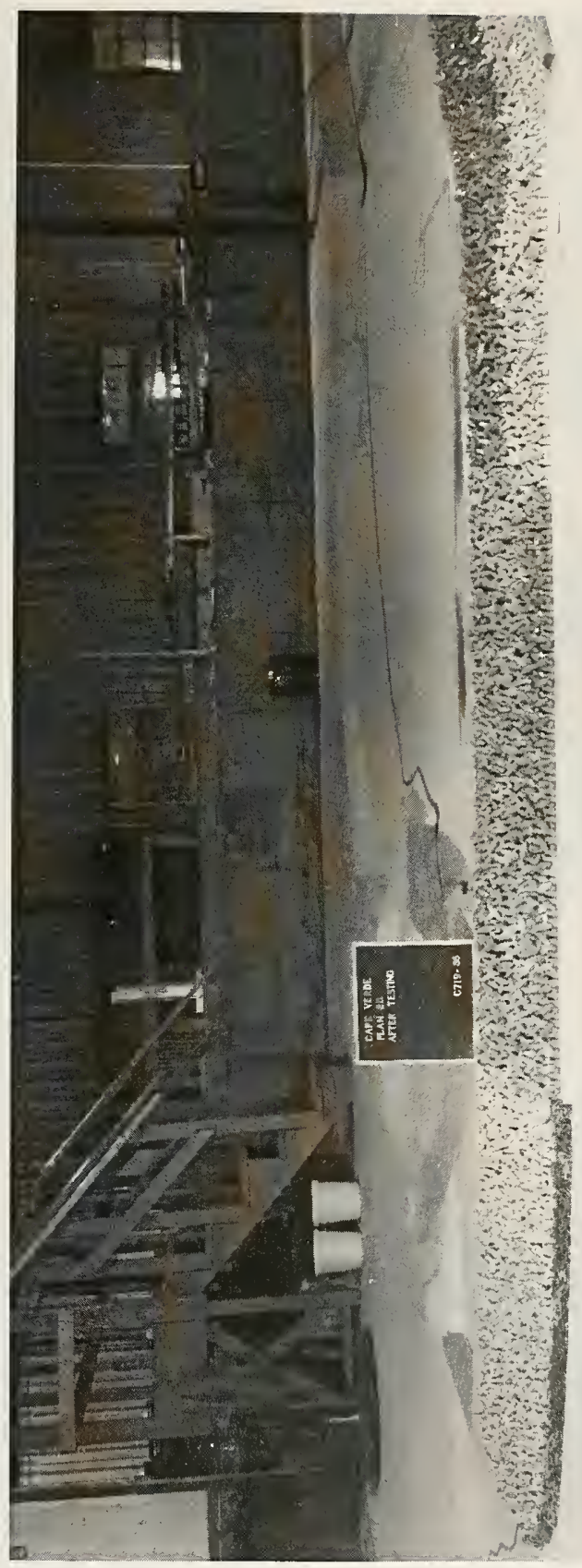

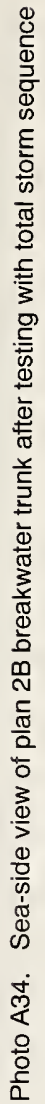




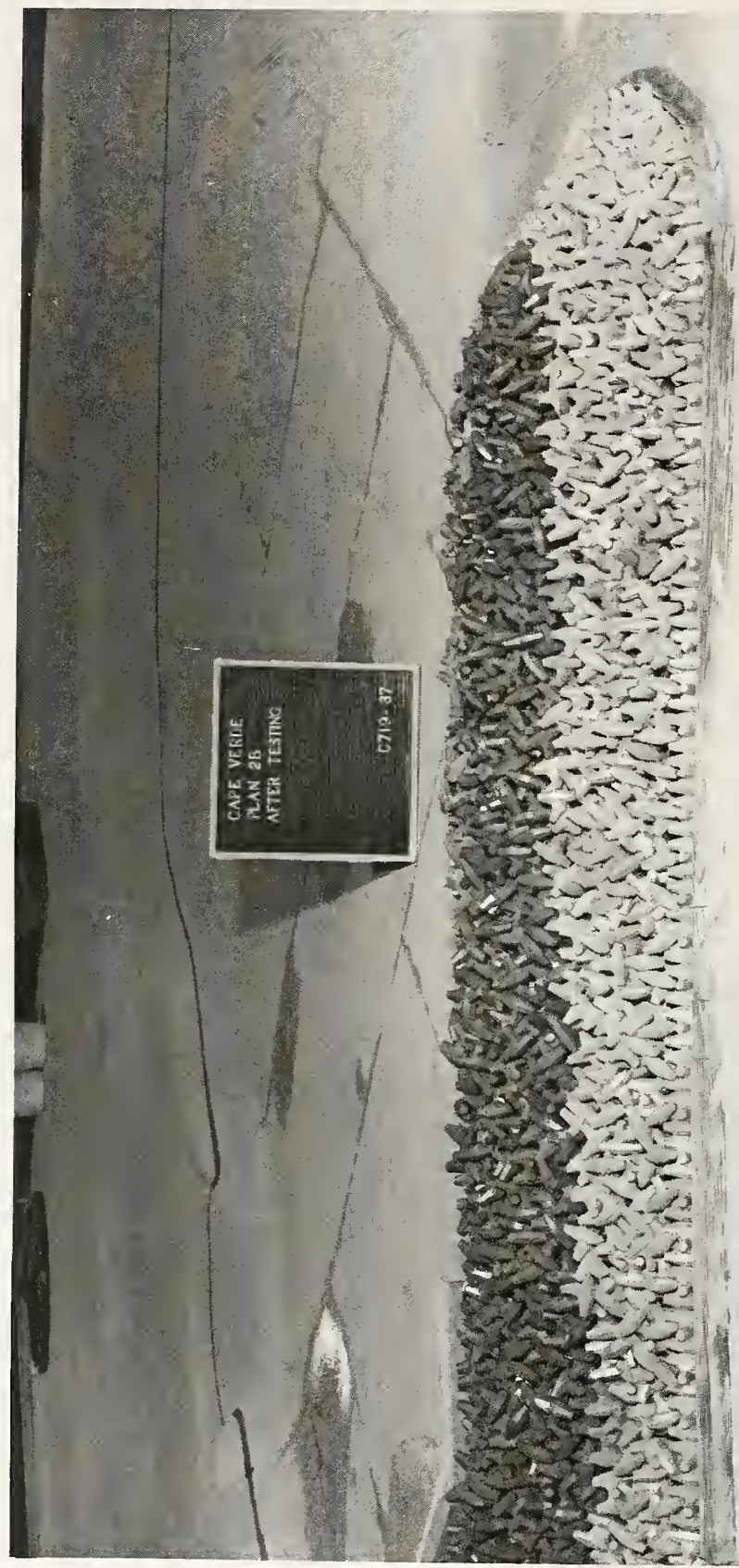

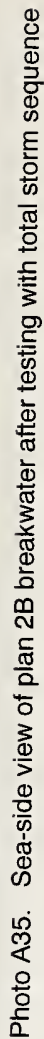




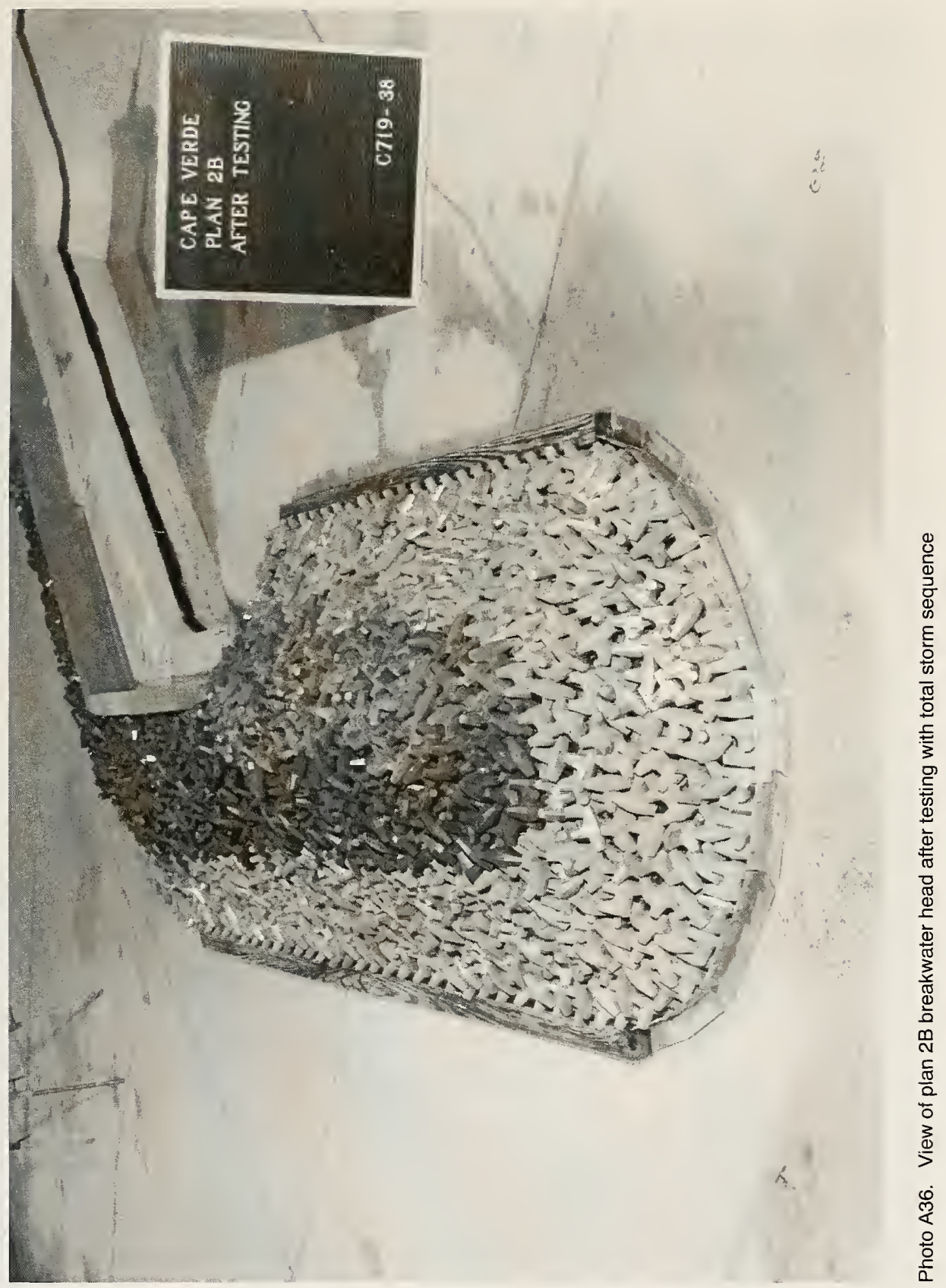



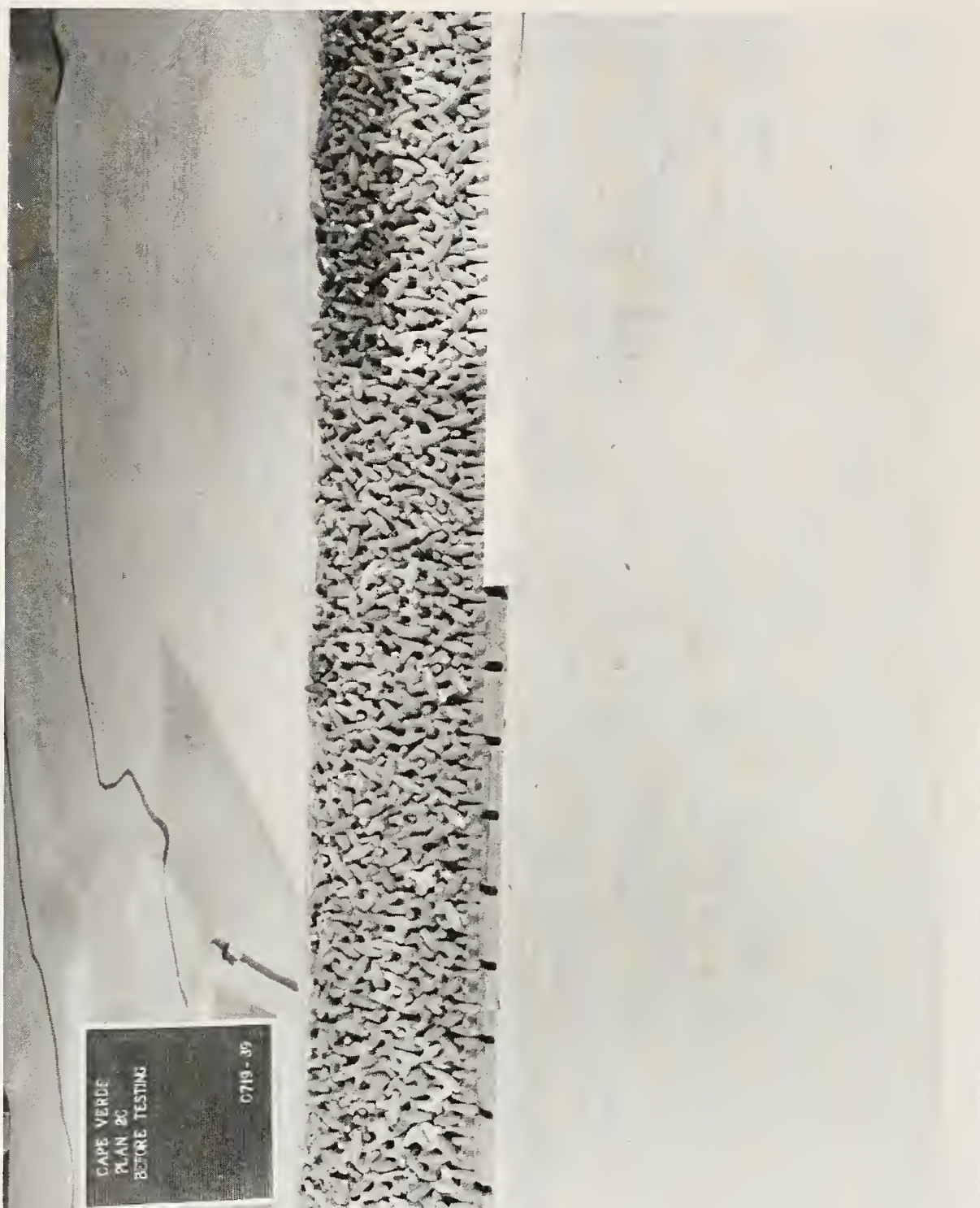

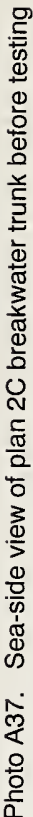




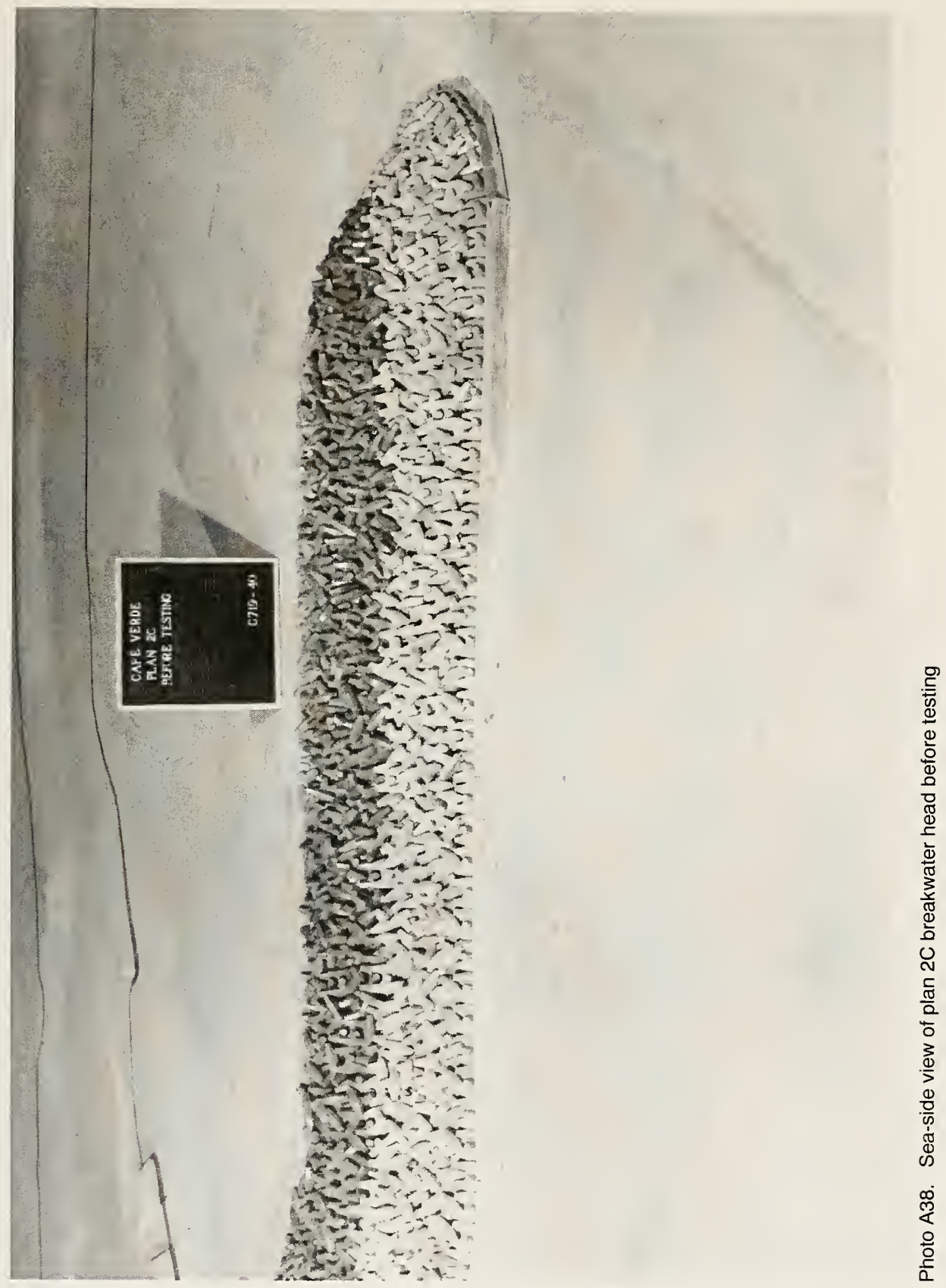




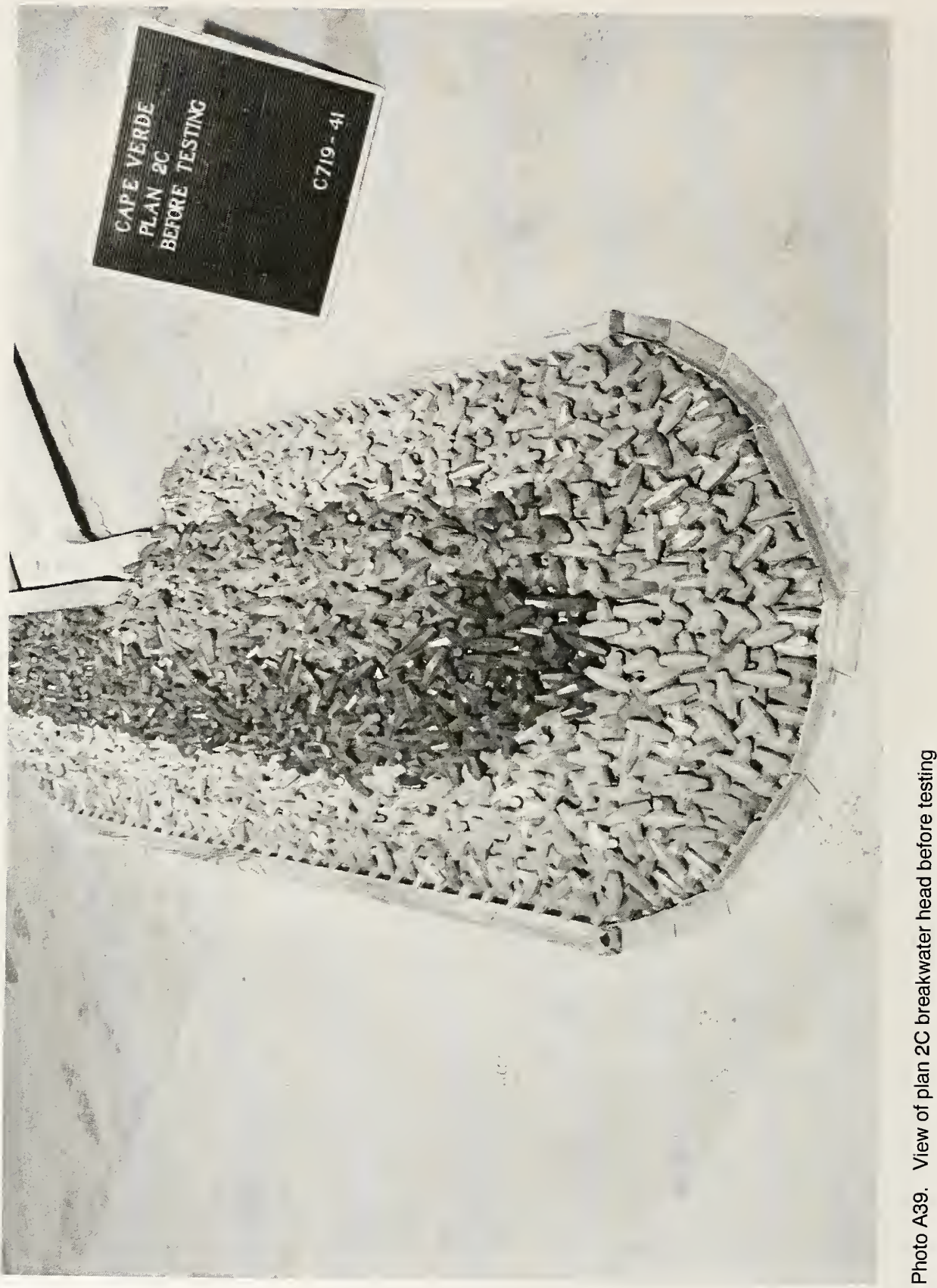




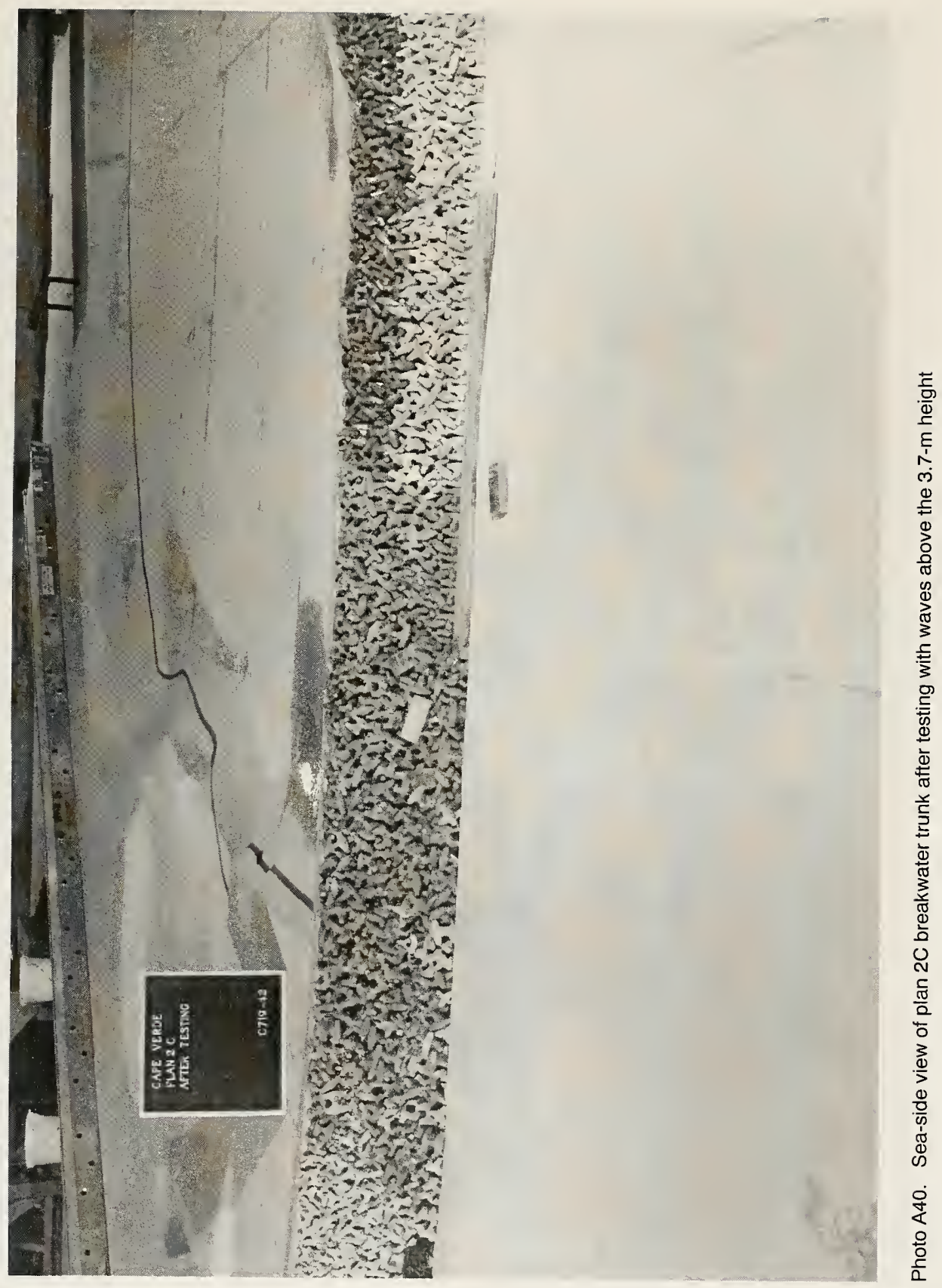




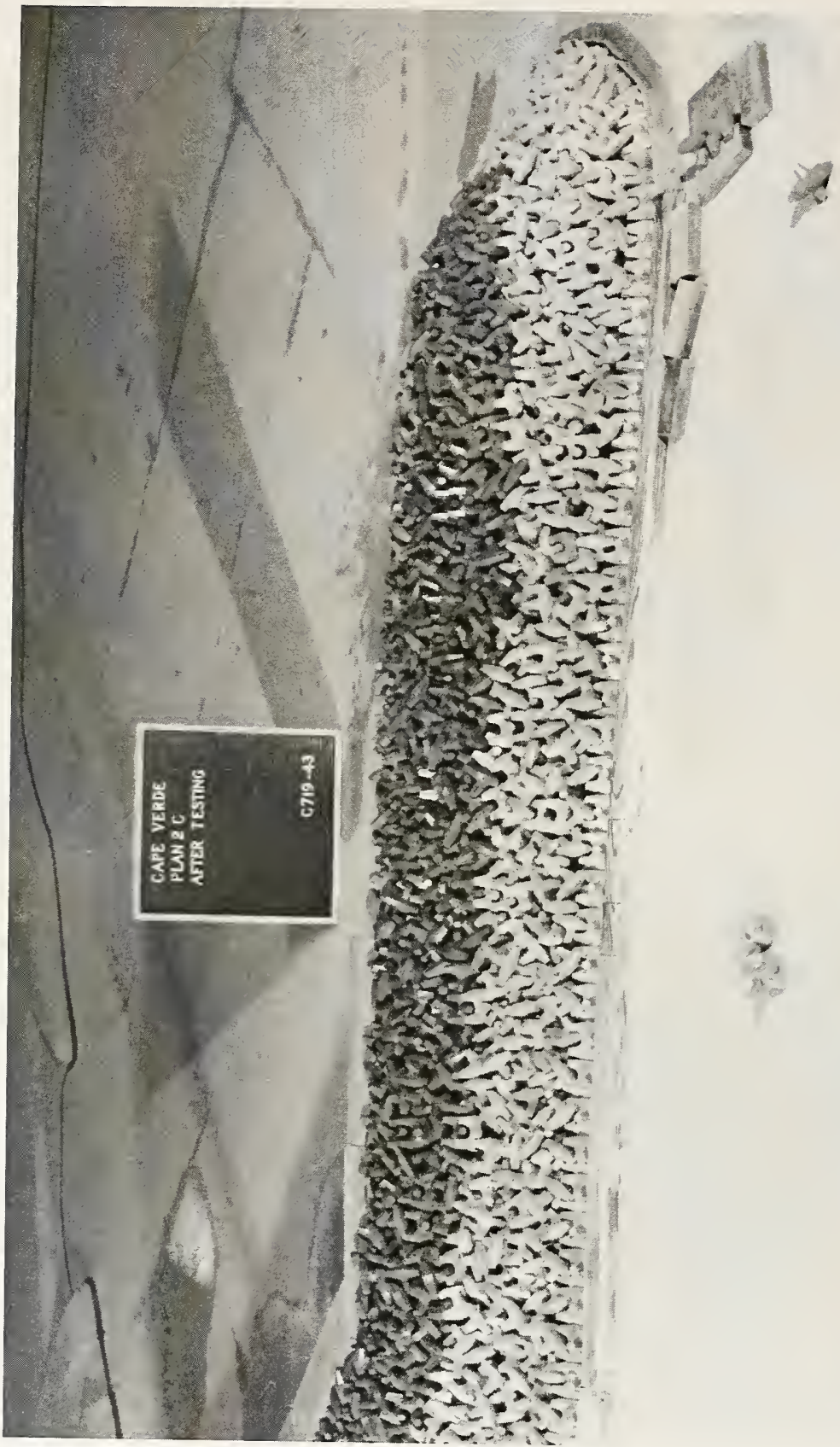

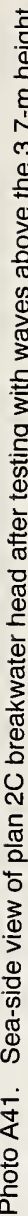




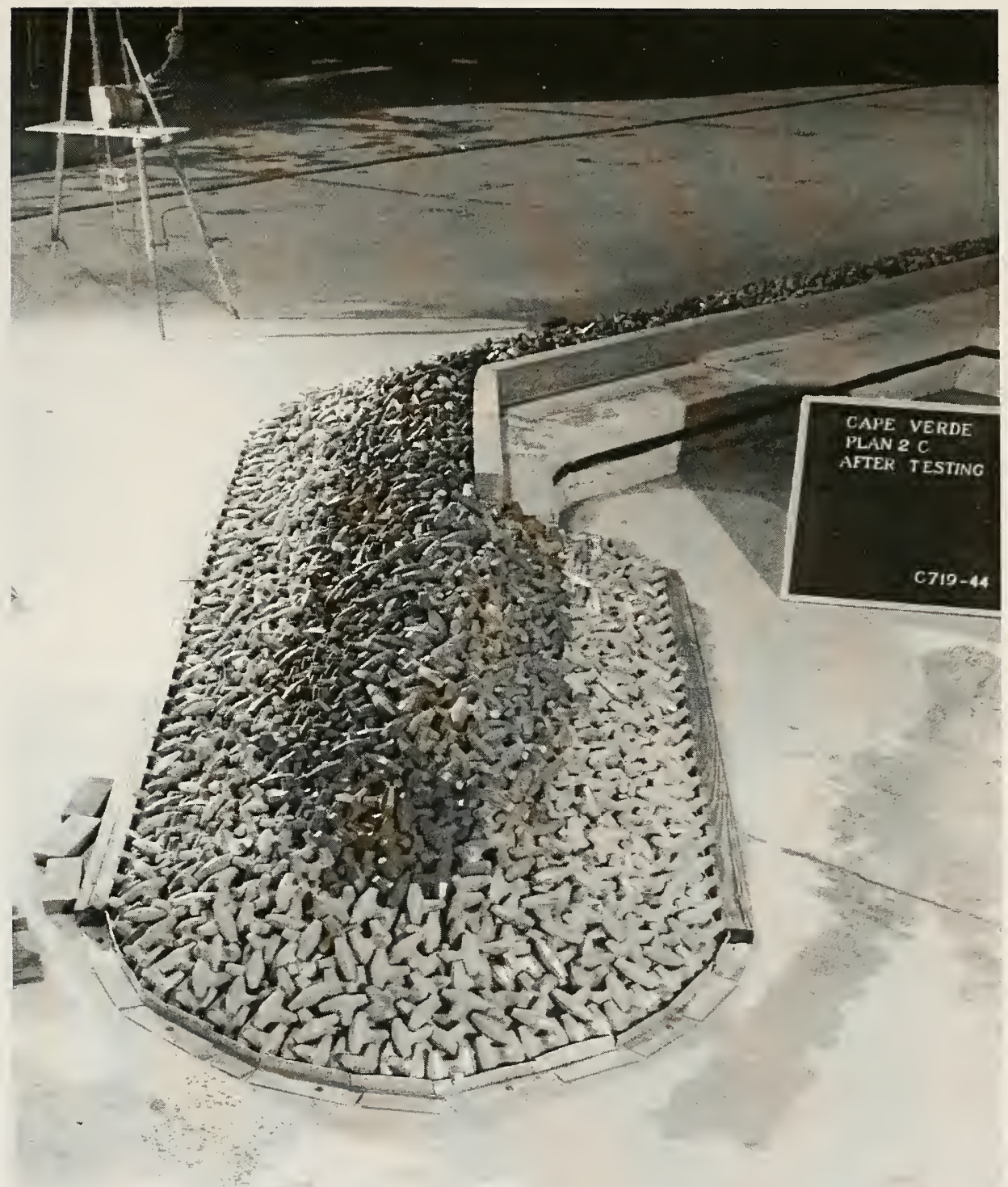

Photo A42. View of plan $2 \mathrm{C}$ breakwater head after testing with waves above the $3.7-\mathrm{m}$ height 


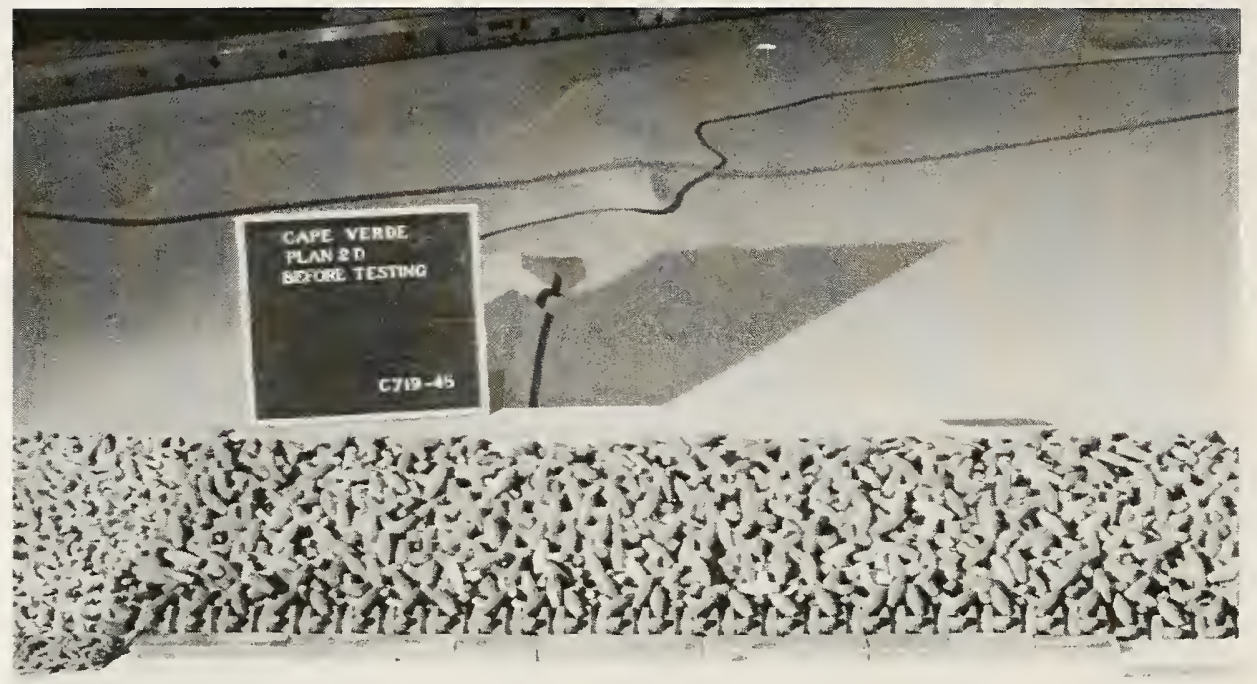

Photo A43. Sea-side view of plan 2D, profiles 4 through 6 , before testing

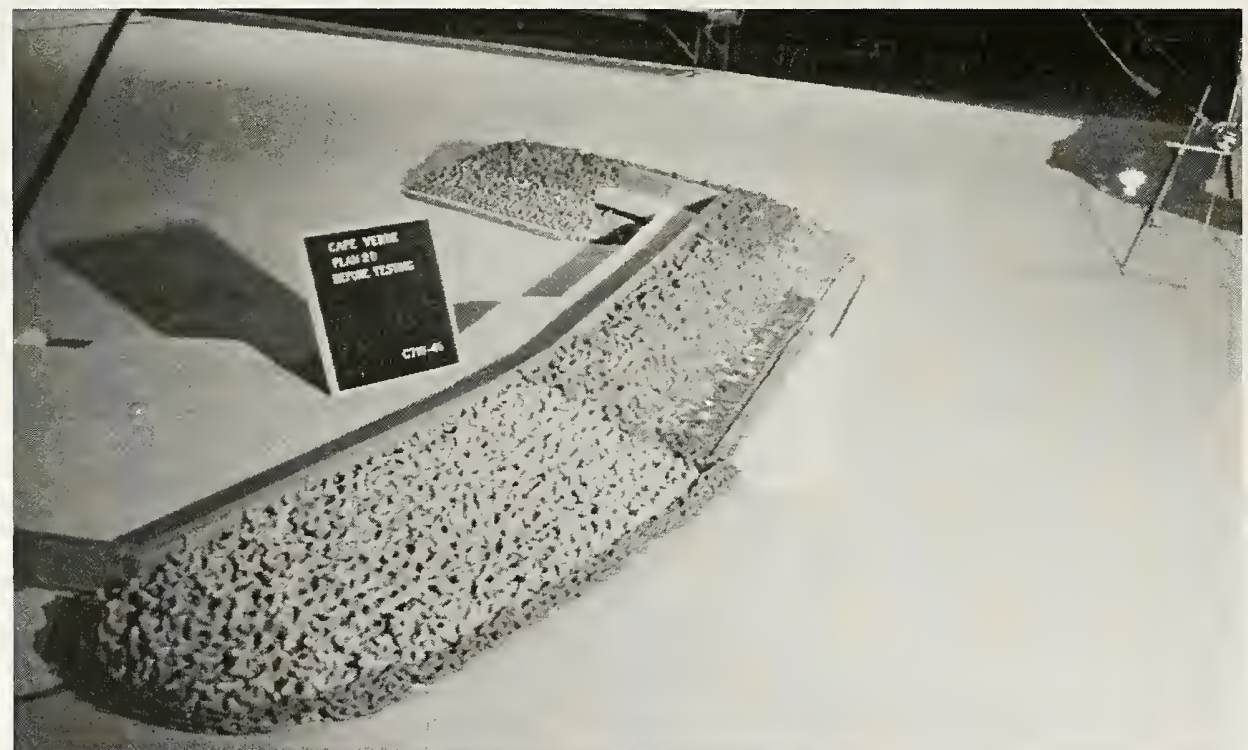

Photo A44. View from north of plan 2D breakwater trunk before testing 


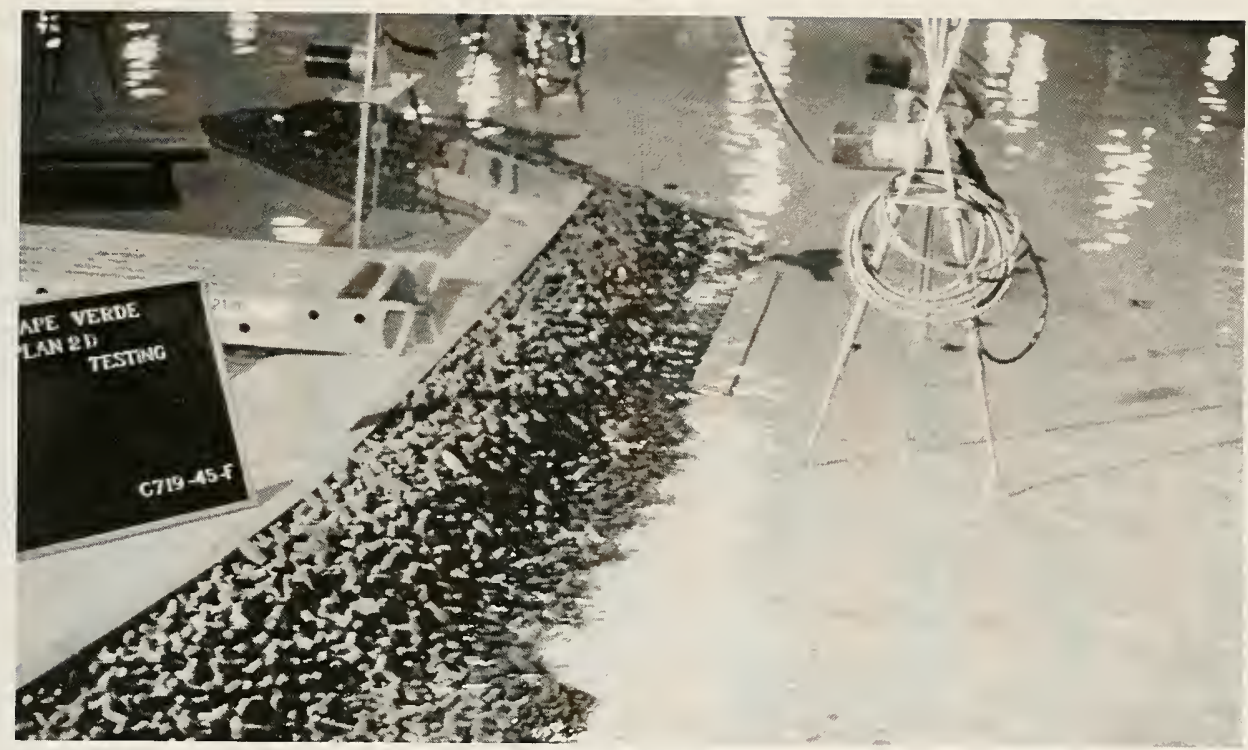

Photo A45. View from north of plan 2D breakwater trunk after testing with total sequence

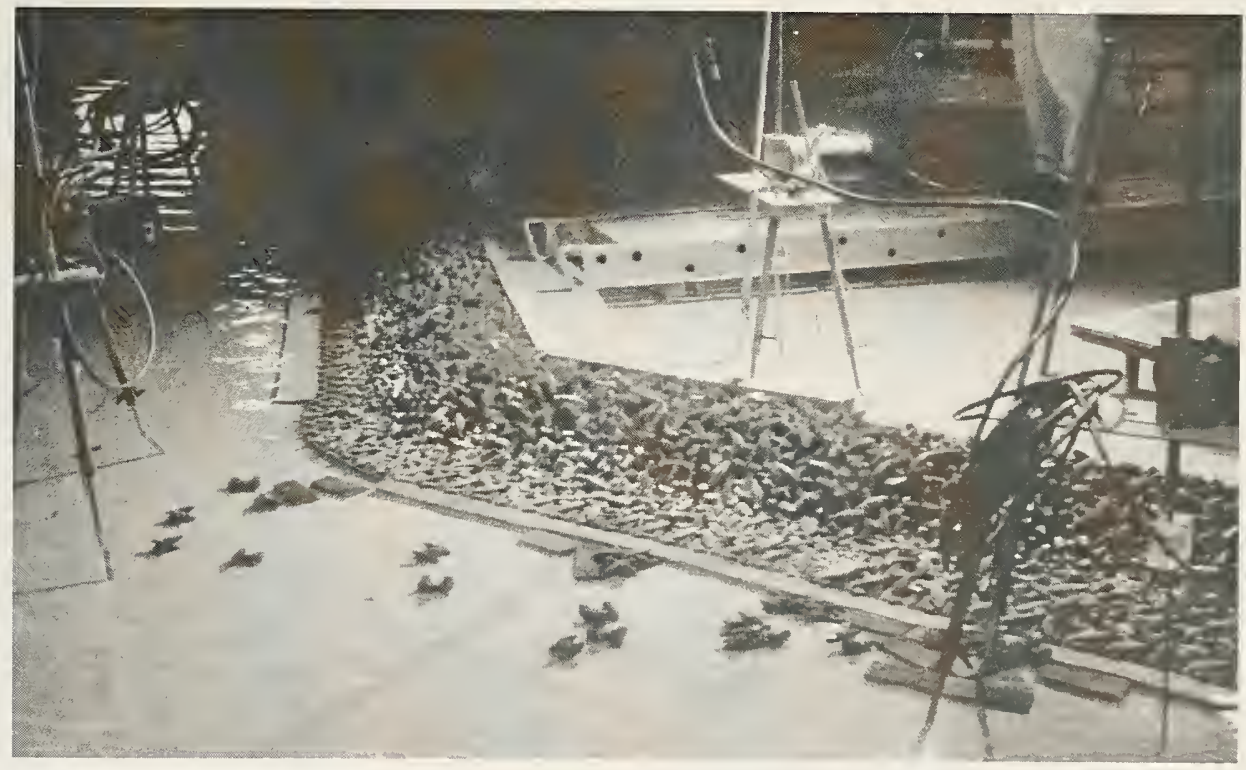

Photo A46. Sea-side view of plan 2D breakwater head after testing with total storm sequence 



\title{
Appendix B Notation
}

\author{
a Area scale \\ A Section area \\ $H_{s} \quad$ Incident significant wave height at $21.3-\mathrm{m}$ mllw depth \\ $H_{m o} \quad$ Zero-moment wave height \\ $H_{s} \quad$ Significant wave height \\ $l \quad$ Length scale \\ m Model quantity \\ $N \quad$ Number of units in a given area \\ $p \quad$ Prototype quantity \\ $r \quad$ Subscript denoting model to prototype \\ $S_{a} \quad$ Specific gravity of an individual armor unit relative to the water in \\ which it is placed, $S_{a}=\gamma_{a} / \gamma_{w}$ \\ $S_{r} \quad$ Density of model and prototype materials \\ $t \quad$ Time scale \\ $T_{p} \quad$ Peak wave period \\ $v \quad$ Volume scale \\ $V \quad$ Armor unit volume \\ $W_{1} \quad$ Weight of an individual unit in armor layer
}


$W_{2} \quad$ Weight of stone in first underlayer

$W_{3} \quad$ Weight of stone in core

$W_{a} \quad$ Weight of an individual armor unit

$\phi \quad$ Packing density

$\gamma_{a} \quad$ Specific weight of an individual armor unit

$\gamma_{w} \quad$ Specific weight of water 


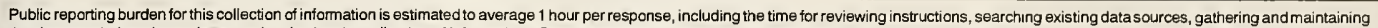

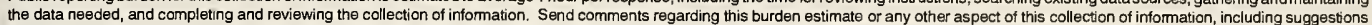

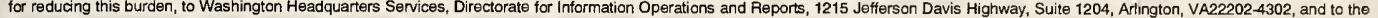
Office of Management and Budget, Paperwork Peduction Project (0704-0188), Washington, DC20503.

\begin{tabular}{|l|l|l|}
\hline 1.AGENCY USE ONLY (Leave blank) & $\begin{array}{c}\text { 2.REPORT DATE } \\
\text { July } 1998\end{array}$ & $\begin{array}{c}\text { 3.REPORT TYPE AND DATES COVERED } \\
\text { Final report }\end{array}$ \\
\hline
\end{tabular}

\section{TITLE AND SUBTITLE}

Three-Dimensional Breakwater Stability Tests at Vale de Cavaleiros, Cape Verde

\section{AUTHOR(S)}

Ernest R. Smith, Jeffrey A. Melby

\section{PERFORMING ORGANIZATION NAME(S) AND ADDRESS(ES)}

U.S. Army Engineer Waterways Experiment Station

3909 Halls Ferry Road, Vicksburg, MS 39180-6199

5.FUNDING NUMBERS

8.PERFORMING ORGANIZATION REPORT NUMBER

Technical Report CHL-98-22

9.SPONSORING/MONITORING AGENCY NAME(S) AND ADDRESS(ES)

10.SPONSORINGMONITORING AGENCY REPORT NUMBER

\section{SUPPLEMENTARY NOTES}

Available from National Technical Information Service, 5285 Port Royal Road, Springfield, VA 22161.

\section{2a.DISTRIBUTION/AVAILABILITY STATEMENT}

12b.DISTRIBUTION CODE

Approved for public release; distribution is unlimited.

\section{ABSTRACT (Maximum 200 words)}

A breakwater rehabilitation has been proposed for Vale de Cavaleiros, Republic of Cape Verde. Rehabilitation would include extending the breakwater length, placing all salvageable tetrapods in the northernmost portions of the breakwater, and placing Core-Loc armor units on the remainder of the structure. A breakwater stability model investigation was initiated by the U.S. Army Engineer Waterways Experiment Station's Coastal Engineering Research Center. The goal of the study was to evaluate the stability of the Core-Loc armor layer for the proposed breakwater rehabilitation. This report describes the rehabilitation design and facilities used, as well as the three-dimensional stability test results.

\section{SUBJECT TERMS}

Breakwater rehabilitation

Breakwater stability

Core-Loc armor units
Tetrapods

Vale de Cavaleiros breakwater
15. NUMBER OF PAGES

$$
79
$$

16.PRICE CODE

19.SECURITY CLASSIFICATION

20.LIMITATION OF ABSTRACT CURITY CLASSIFICATION OF REPORT

18.SECURITY CLASSIFICATION
OF THIS PAGE
UNCLASSIFIED

UNCLASSIFIED OF ABSTRACT NSN 7540-01-280-5500
Standard Form 298 (Rev. 2-89) Prescribed by ANSI Std. Z39-18 298-102 

Destroy this report when no longer needed. Do not return it to the originator. 


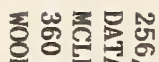

悹

응 흥

㷎融

品

웡단

ध $8 * \infty$

空

I

en

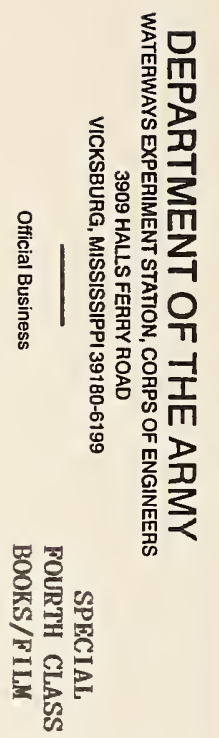

